Florida International University FIU Digital Commons

\title{
School desegregation in Broward County, Florida 1970-1998: a historical study of power
}

Janice Boursiquot

Florida International University

DOI: $10.25148 /$ etd.FI14051809

Follow this and additional works at: https://digitalcommons.fiu.edu/etd

Part of the Educational Administration and Supervision Commons, Educational Assessment, Evaluation, and Research Commons, and the Higher Education Commons

\section{Recommended Citation}

Boursiquot, Janice, "School desegregation in Broward County, Florida 1970-1998 : a historical study of power" (2003). FIU Electronic Theses and Dissertations. 1750.

https://digitalcommons.fiu.edu/etd/1750 
FLORIDA INTERNATIONAL UNIVERSITY

Miami, Florida

SCHOOL DESEGREGATION IN BROWARD COUNTY, FLORIDA 1970-1998:

A HISTORICAL STUDY OF POWER

A dissertation submitted in partial fulfillment of the

requirements for the degree of

DOCTOR OF EDUCATION

in

ADULT EDUCATION AND HUMAN RESOURCE DEVELOPMENT

by

Janice Boursiquot 
To: $\quad$ Dean Linda Blanton

College of Education

This dissertation, written by Janice Boursiquot, and entitled School Desegregation in Broward County, Florida 1970-1998: A Historical Study of Power, having been approved in respect to style and intellectual content, is referred to you for your judgment.

We have read this dissertation and recommend that it be approved.

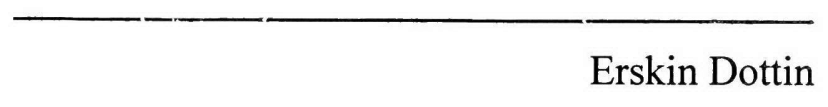

$\overline{\text { Mohammed K. Farouk }}$

Charles Divita, Major Professor

Date of Defense: July 21, 2003

The dissertation of Janice Boursiquot is approved.

Dean Linda Blanton

College of Education

Dean Douglas Wartzok

University Graduate School

Florida International University, 2003 
(C) Copyright 2003 by Janice Boursiquot

All rights reserved. 


\section{DEDICATION}

This dissertation is dedicated in loving memory to my mother, Naomi Bowers and to my father, James Robinson. Without their nurturance, guidance and influence on my life, none of the things I have accomplished in life would have been possible. It is also dedicated to my son Francois, who gave me the time and space I needed to spend endless hours working on the completion of this dissertation.

In addition, I dedicate this dissertation to my "sisterhood" and friends who did not abandon me when I did not return phone calls or respond to invitations, who also gave me the encouragement to keep striving.

I dedicate this dissertation to all the children and parents with whom I had the opportunity to work over the years, and who are responsible for stimulating my interest in the issue of school desegregation and power in the Broward County School System.

I also dedicate this dissertation to all those persons in the community and inside the School System who have taken an affirmative position on behalf of, in defense of and in the best interest of those children who were the most vulnerable 


\section{ACKNOWLEDGMENTS}

It is with deep appreciation and sincere thanks that I acknowledge the many people who assisted me on this journey. I am deeply indebted to the Chair of my Dissertation Committee, Dr. Charles Divita, for his assistance, encouragement and advocacy. He came to my assistance at crucial times during this extended journey. $\mathrm{He}$ provided me with his scholarly insight and challenged the scholarship within me.

I am very grateful to my committee members (Dr. Erskin Dottin and Dr. Mohammed Farouk) who were very supportive, and came to my rescue after I had to reconfigure my Committee three times. Dr. Thomas Johnson, who was the first Chairman of my Dissertation Committee, encouraged me to study the issue of desegregation and power in the Broward County School System. Dr. John Carpenter provided the primary impetus for my enrolling at Florida International University. I appreciate Dr. Frank Di Vesta's professional guidance and expertise as he steered me through the arduous and painstaking process of editing my dissertation for intellectual content and compliance with APA format guidelines.

Donna Moriarity in Dr. Di Vesta's office made my life a lot less stressful by running interference between me (living in Broward County) and the University, located in southwest Dade County. She was always cheerful, accommodating, reassuring and efficient in helping me to meet the many deadlines; typing and submitting forms, and obtaining signatures. I thank all the participants who gave of their time to be interviewed, with a special thanks to Levi Williams and Mary Fertig for providing me with archival data. 
ABSTRACT OF THE DISSERTATION

SCHOOL DESEGREGATION IN BROWARD COUNTY, FLORIDA 1970-1998:

A HISTORICAL STUDY OF POWER

by

Janice Boursiquot

Florida International University, 2003

Miami, Florida

Professor Charles Divita, Major Professor

This is a historical case study on school desegregation and power in Broward County, Florida from 1970 to 1998 . The purpose of this study is to describe, explain and analyze types of power used by the School Board of Broward County, Florida and community activists, in their efforts to influence desegregation decisions from 1970 to 1998. In addition, this study explains who benefited and who won from the School Board's desegregation decisions and who governed those decisions?

A historical case study approach was used as the method for conducting this study. Data sources included 11 interviews of individuals who were involved in school desegregation issues as either School Board officials or community activists and 10 archival data sources.

The theoretical models of Russell, Galbraith, Wartenberg and Domhoff were used to determine the different types of power techniques used by School Board officials and community activists and to answer the questions: who benefited and who won from the School Board's desegregation decisions and who governed those policies and practices? 
The primary beneficiaries of school desegregation policies and practices in Broward County were: white, affluent communities and the builders, developers, realtors and other businesses in the western suburban communities. All of the data sources indicated that the black community did not benefit from the School Board's desegregation policies.

The primary power techniques used by School Board officials to influence desegregation policies and practices was "power over opinions" and compensation. These power techniques were manifested by the School Board publicly disputing the allegations raised by community activists and by compensating those who supported and promoted the School Board's desegregation policies and practices.

The power techniques primarily used by community activists were coercive force and "power over opinions." They effectively used these power techniques to change the School Board's policies and practices they felt were detrimental to black children and the black community.

Based on the analysis of the qualitative data, it can be concluded that black children did not benefit from school desegregation in Broward County, Florida and the community continues to suffer residual effects from past desegregation policies and practices. 


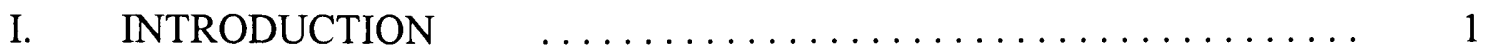

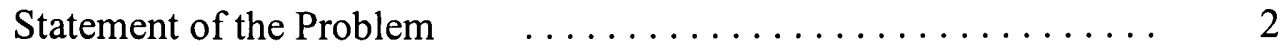

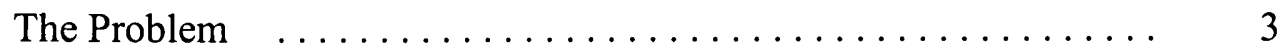

General Statement of Research Area $\quad \ldots \ldots \ldots \ldots \ldots \ldots \ldots .4$

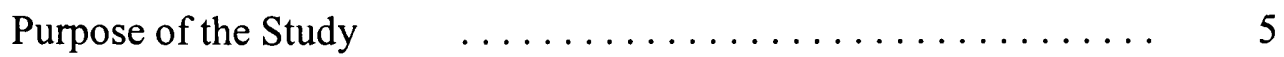

Significance of the Study Theoretical Perspective $\quad \ldots \ldots \ldots \ldots$. 5

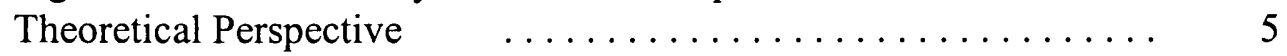

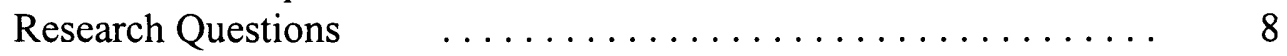

Assumptions of the Study $\quad \ldots \ldots \ldots \ldots \ldots \ldots \ldots \ldots \ldots$

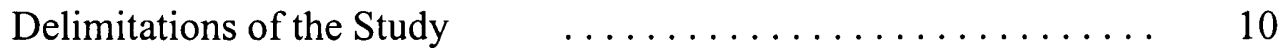

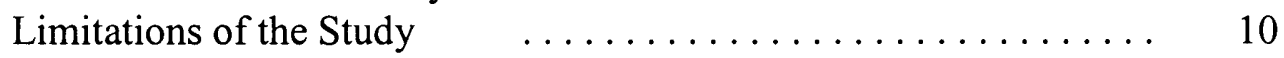

Ethical Responsibilities $\quad \ldots \ldots \ldots \ldots \ldots \ldots \ldots \ldots \ldots, 10$

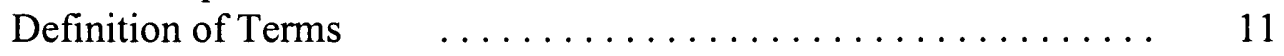

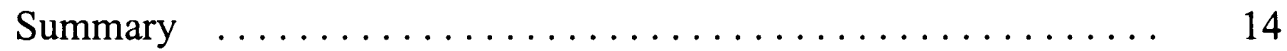

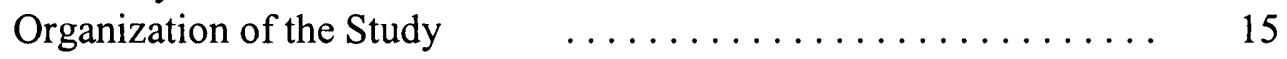

II. REVIEW OF THE LITERATURE $\ldots \ldots \ldots \ldots \ldots \ldots \ldots \ldots \ldots$

Historical Overview of School Desegregation in the United

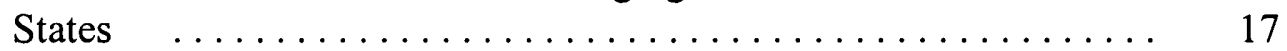

Historical Overview of Desegregation in Broward County,

Florida .............................. 38

Review of Historical Case Study Dissertations on School

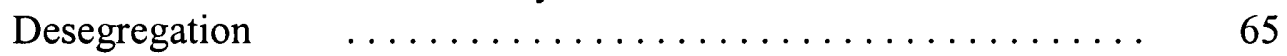

Review of the Literature on Power $\quad \ldots \ldots \ldots \ldots \ldots \ldots \ldots . \ldots 6$

Summary $\ldots \ldots \ldots \ldots \ldots \ldots \ldots \ldots \ldots \ldots \ldots \ldots \ldots \ldots$

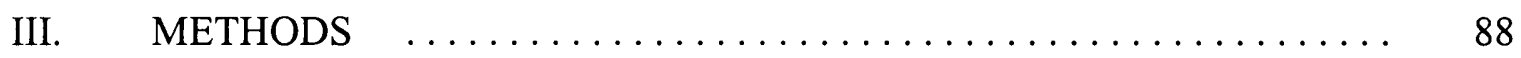

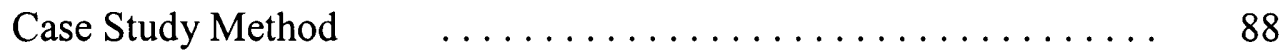

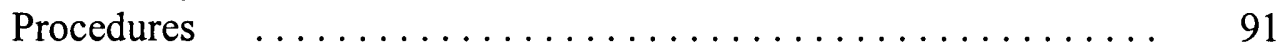

Description of Researcher's Role $\quad \ldots \ldots \ldots \ldots \ldots \ldots \ldots \ldots, 101$

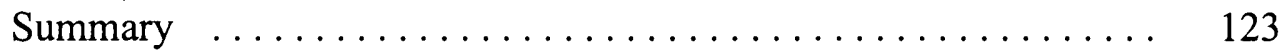

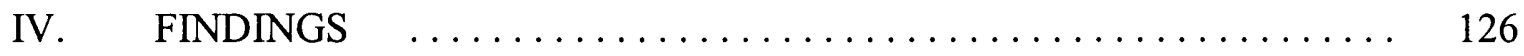

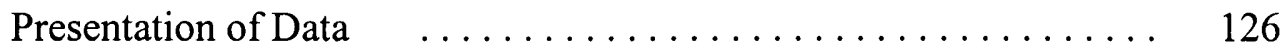

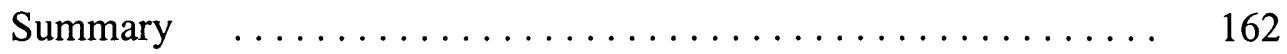

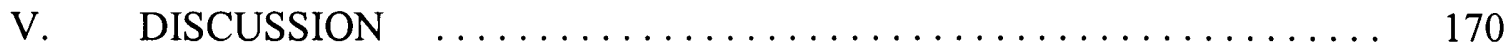

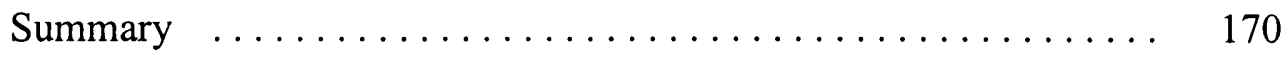

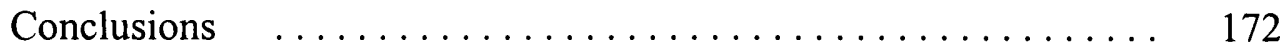

Recommendations for Further Research $\quad \ldots \ldots \ldots \ldots \ldots \ldots .189$ 
1. Racially Identifiable Schools

2. Elementary Schools Opened Since the 1970 Desegregation

Court Order

3. Number of Elementary Schools to Which Students Were Bused in Starbursted Communities

4. Chronology of Desegregation Events 66

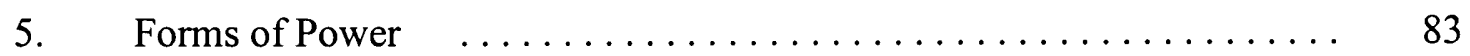

6. Cross-Reference of Interview and Research Questions $\quad \ldots \ldots \ldots \ldots . \quad 98$

7. Cross-Reference of Research Questions with Domhoff's

Power Indicators

8. Cross-Reference of Archival Data

9. Disparity in Black and White Students Bused to

Desegregate Schools

10. Students in Special Education Classes/Programs $\ldots \ldots \ldots \ldots \ldots \ldots$

11. Suspension Rate Difference for Black Students Compared to White Students

12. Research Question \#1: What Are the Factors That Made School Desegregation an Important Power Issue in Broward County?

13. Research Question \#2: Who Were the Principal Players Who Governed the School Board's Desegregation Policies and Practices?

14. Research Question \#3: What Were the Power Techniques Used by the Principal Players to Influence Desegregation Policies and Decisions?

15. Research Question \#4: How Were Decisions Made Regarding School Desegregation? Who Was Consulted? Who Was Involved in Desegregation Decisions? 
16. Research Question \#5a: Were There Any Individuals or Groups That Were Successful in Influencing Desegregation in Broward County? If So, Who Were They?

17. Research Question \#6a: Who Benefited the Most and Who Won from the School Board's Desegregation Policies and Practices? Who Governed Those Policies and Practices?

18. Research Question \# 7: What Was the Response from the Overall African American Community to the School Board's Desegregation Policies, Plans, and Practices? 


\section{CHAPTER I}

\section{INTRODUCTION}

This is a historical case study of desegregation in the School System of Broward County, Florida and power from 1970 to 1998 . The School System in Broward County was ordered by the Court to desegregate in 1971 in response to a lawsuit filed by Attorney George Allen on behalf of his two children (Allen vs. Broward County, 1979).

Like many other school districts throughout the United States, Broward County was slow to respond to the Supreme Court Orders handed down in 1954 and 1955, commonly known as Brown I and Brown II. The first Supreme Court ruling found racial segregation to be in violation of the $14^{\text {th }}$ Amendment to the Constitution of the United States and segregated schools to be inherently unequal. The second decision ordered school districts to desegregate with all deliberate speed (Armor, 1995; Wiley, 1994; Lawrence, 1980). Broward County did not implement these Supreme Court Orders for another 16 years. Broward County's response to the foregoing Order followed the filing of a desegregation lawsuit by George Allen in 1971 (Allen vs. Broward County, 1979).

Several desegregation lawsuits have been filed against the Broward County School Board since Attorney Allen filed his initial desegregation lawsuit (Banker, 1995a; Citizens Concerned About Our Children vs. Broward County, 1995a; Fernandez, 1992; Kiffin, 1995a; Marks, 1992; Smith vs. McFatter, 1983; Washington vs. Broward County, 1995a). A grassroots group called Citizens Concerned About Our Children (CCC) filed the most recent lawsuit in 1995, charging the School Board with bias and discriminatory treatment, as well as with inequitable policies and practices against black children. The 
School Board settled with the group in August 2000 for $\$ 485,000$ (Ferrechio \& Arthur, 2000; Marshall, 2000).

\section{Statement of the Problem}

There is nothing in American society more fraught with problems than race relations. Brown vs. Board of Education was an attempt to address the intransigence of race relations in this country. Thus, school systems became the incubators for race relations. However, some people have argued that the solutions became the problem (Armor, 1995; Bell, 1989; Freeman, 1980; Lawrence, 1980; Turner, 1994; Wiley, 1994).

During the first 12 years (1970 - 1982) of desegregation in Broward County, Florida, the desegregation plan seemed to receive relatively broad-based support throughout the community from blacks and whites, as well as from the leadership in the School System. However, during the following years, the support for the School Board's desegregation plan began to wane in both the white and black communities as animosity began to grow and escalate between the leadership in those communities and the grassroots populations and between the School Board and the grassroots (Ft. LauderdaleNAACP, personal communication, March 8, 1991; C. Moore, personal communications, September 9, 1997 and May 2, 1988; NABSE, personal communication, November 11, 1986; Roundtable on Education, personal communication, November 5, 1986; H.

Steinholz, personal communication, May 14, 1992; R. Walters, personal communications, September 1, 1989 and July 8, 1992; Fernandez, 1992; Marks, 1991a, 1992, 1993; Pugh, 1992).

Many in the black community began to doubt the wisdom of and dispute the benefits of desegregation to black children, and asserted that black children were being 
used and exploited as pawns in a Court Order to desegregate the School System. The eastern white faction of the County felt they were being unfairly used and excessively inconvenienced because they were less affluent, in closer proximity to the black community and wielded less political clout than the white families who had moved out west. It was speculated that many moved west to purposely avoid the busing of their children to predominately black schools on the east side of town and that they had no intention or desire to participate in the School System's desegregation plan ("Broward County Resegregated," 1996; "Busing and Boundaries," 1991; Clayborne, 1991; Marks, 1990, 1991b, 1991c, 1993, 1994; Payne, 1994; "School Busing Issue," 1991; "Schools and Segregation," 1991; Williams, 1993).

\section{The Problem}

For approximately 12 years (1986-1998), grassroots communities showed growing discontent with the desegregation policies, practices, and plan of the Broward County School System (“Black Parents Enraged,” 1986; Boehlin, 1990; Marks, 1990, 1991a, 1991b, 1994; "NAACP Education Activists," 1990; Owens, 1990; Payne, 1991; "School Busing Issue," 1991; Woodall, 1989; Work, 1991a, 1991b, 1991c, 1992). By 1994-95 this discontent climaxed into a very public dispute in the community with some black leaders and School Board officials on one side of the issue and grassroots communities on the other side (black and white).

The School Board's desegregation plan, which was supported by many of the black leadership, was the target of criticism and ridicule. Black and white parent groups that had previously opposed each other now joined forces against the School Board and the leadership in the community to demand changes in the desegregation plan. Black and 
white education activists and parents argued that the School Board's desegregation plan did not work, was unfairly and inequitably implemented, was disruptive to families, and denied educational opportunities to black children (Banker, 1995a, 1995b, 1995c, 1995d, 1995e; Banker \& Williams 1995; Clayborne, 1995a, 1995b; "Fresh Eyes," 1995;

Hirschman, 1995; Ishoy, 1995; Kiffin, 1995a, 1995b; Marks, 1994, 1995a, 1995b, 1995c;

"School Board Hit," 1995; Work, 1995).

The School Board's typical response was that their desegregation policies, practices and plan were based on a mutually agreed upon settlement agreement (1987 Consent Decree) between the School Board and Attorney George Allen. There was little reconciliation of the concerns and issues voiced by education activists, parents and the School Board and certain leaders in the community. Therefore, a power struggle ensued between education activists and parents over the disproportionate numbers of black children who were bused; black children being starbursted (a form of busing only applied to black children); black children being denied access to magnet programs; and the failure of the School Board to bus children from predominately white and affluent communities in the west to predominately black schools in the east ("Black Children Being Used," 1995; “Blacks Will Mount," 1995; Ishoy, 1995; Kiffin, 1995b, 1995c, 1995d, 1995e, 1995f).

General Statement of Research Area

The problem to be examined involves the forms and exercise of power between the Broward County School System and the black community regarding school desegregation from 1970 to 1998. 
The purpose of this study is to describe, explain and analyze the forms and uses of power by the School Board of Broward County, Florida and the grassroots community in their efforts to influence desegregation from 1970 to 1998.

These issues were explored in the context of school desegregation to determine (a) how power was used and manifested in desegregation decisions in Broward County, and (b) who benefited from the School Board's desegregation plan(s) and policies, who governed the development of those plan(s) and who won from the exercise and impact of power in school desegregation decisions in Broward County.

\section{Significance of the Study}

Desegregation in the Broward County School System has been a source of debate, contention and strife between the School Board and the community for more than a decade. In 1995, the school desegregation issue climaxed into a massive and bitter protest against the School Board and its' outside agents by a newly created multi-ethnic and multi-racial grassroots movement. Within the framework of a historical case study of school desegregation in Broward County, the potential significance of this study will be to learn lessons from which the School System, community and activists can benefit and to develop an informed analysis of the past and present desegregation policies and practices and their impact on the community.

\section{Theoretical Perspective}

The theoretical perspective for this study is based on G. William Domhoff's indicators of how to measure power; John Kenneth Galbraith's, Anatomy of Power; Thomas E. Wartenberg's “power-over” and Bertrand Russell's forms of power. 
C. Wright Mills, a power structure theorist, created the concept of institutional elitism in the 1950's. He asserted that America was ruled by a "power elite" that was based in the three most important hierarchies in the country; the executive branch of the federal government, the military and in corporations. He further elaborated by saying:

To the extent there is a ruling class, ordinary citizens must go outside of normal channels, engaging in risky, unacceptable activities in order to get their issues addressed. In doing so the government may foil and complicate these efforts to protect the interests of big business" (Miller, 1984, p. 113).

Domhoff, a power-structure theorist, proposed three different types of indicators by which to measure power: (a) Who benefits? (b) Who governs? and (c) Who wins? These three indicators were applied when examining the issue of power in this study. The answers to the research questions were found in an examination of who benefited by the School Board's desegregation policies, who governed the School Board's desegregation policies and who won whenever there was a dispute over the policies?

Galbraith postulates that there are three basic ways in which power is exercised or enforced. He classifies them as condign, compensatory and conditioned (Galbraith, 1983).

1. Condign power forces a person to abandon his/her pursuits in the face of physical or emotional threats.

2. Compensatory power forces submission by offering or promising a reward or payment for the abandonment of a pursuit.

3. Conditioned power has more of a psychological function to it. The person is persuaded or influenced to do something without being aware of it. 
Galbraith also proposes three different sources of power: personality, property, and organization. Personality refers to the quality and influence of a person's physique, mind, speech, moral certainty, aura and other traits. Property has always been thought to give access to social and political influence and to contain intrinsic power over the conditioned beliefs of people. Organizations, Galbraith submits are the most important of the three sources because they have access to condign power and compensatory power by virtue of their natural and normal association with property. Organizations also have access to conditional power (Galbraith, 1983).

Wartenberg proposed three different forms of power: force, coercion and influence.

1. Force of power is when physical or non-physical means are used to prevent another person from accomplishing his/her objectives.

2. Coercive force is successful when a person has the capacity to exercise some kind of influence over another person's behavior and decisions based on a threat.

3. Influence and its forms include rational persuasion, personal persuasion, expertise and manipulation. (a) Rational persuasion is exercised when a person influences another person's perspective by providing information. (b) Personal persuasion is exercised through charisma and one's social status rather than through reason. (c) Expertise is exercised when a person accepts information as being valid because it is assumed that the person providing the information is an expert and is providing reliable, correct, and authentic information. (d) Manipulation is the final type of power 
described by Wartenberg. He speaks of cognitive and emotional manipulation. The first is exercised when a person deliberately tries to influence another person's actions by withholding, modifying or distorting information, purpose and intent. Emotional manipulation is a conscious appeal to play on a person's feelings in order to obtain a specific response and action (Wartenberg, 1990).

Russell theorized that there are seven different forms of power: priestly power, kingly power, naked power, revolutionary power, economic power, power over opinions, and the power of creeds as sources of power (Russell, 1938). Russell posits that a person can be influenced by direct physical power over his body, by rewards and punishments as inducements and by influence on opinions (Russell, 1938). "The forms of power that an individual will choose to use will depend upon his temperament, opportunities and skill" (Russell, 1938, p. 266). Organizations, he asserts, can be distinguished by the kind of power they exert. Economic organizations will ordinarily use rewards and punishments as incentives and deterrents; schools, churches, and political parties will most likely use influencing opinions (propaganda being only one type); the military and police will exercise coercive power (Russell, 1938).

\section{Research Questions}

1. What are the factors that made school desegregation an important power issue in Broward County?

2. Who were the principal power players that governed the School Board's desegregation policies and practices? 
3. What were the power techniques used by the power players to influence desegregation policies and decisions?

4. How were decisions made regarding school desegregation? Who was consulted? Who was involved in desegregation decisions?

5a. Were there any individuals or groups that were successful in influencing desegregation in Broward County? If so, who were they?

5b. In what way did they influence desegregation or what was the impact of their involvement?

6a. Who benefited the most and who won from the School Board's desegregation policies and practices?

6b. What were the benefits?

7. What was the response from the overall African American community to the School Board's desegregation policies, plans, and practices?

Assumptions of the Study

The following basic assumptions underlie the study:

1. The participants contributing to this research project expressed their opinions truthfully and accurately.

2. The information from archival data is accurate.

3. Power was a factor in the decision-making process of the Broward County School Board regarding desegregation.

4. There was a power relationship between School Board officials and people in the community regarding desegregation. 
1. The study was restricted to examining the relationship of power between officials in the Broward County School System and the grassroots community (defined as the common people who are outside of the realm of power and influence) from 1970 to 1998 .

2. Desegregation in Broward County was examined from 1970 to 1998, from the perspective of power and power relationships in school desegregation decisions.

\section{Limitations of the Study}

1. The study is limited by the potential for biased reporting on the part of the participants interviewed.

2. The study is limited by the potential for flawed archival data due to negligence or the deliberate attempt to conceal and or distort information.

\section{Ethical Responsibilities}

Research ethics usually center on issues of harm, consent, privacy, confidentiality, and anonymity (Berg, 1998). Many issues and questions related to ethics in qualitative research directly respond to conducting observations. Those concerns are not relevant to this study because observation was not used as a data-collecting tool. Instead the collection of historical data and interviews was used. Therefore, the relevant ethical issues are the following:

1. Being open and honest with participants about the intent, purpose and scope of research. 
2. Maintaining the anonymity of people that provided data for this researcher in an informal manner.

3. Obtaining permission from participants to tape record the interviews.

4. Ensuring that the results of the research will be relevant to the community.

5. Ensuring that there will be no negative consequences to any of the participants.

6. Determining with the participants whether their identity should be confidential.

7. Avoiding over identification with participants and personal bias.

8. Maintaining objectivity throughout the research process.

\section{Definitions of Terms}

Technical terms as they appear in the text are defined in order to provide consistency of thought and understanding to and between the researcher and the reader.

Bi-racial Committee. A committee of the School Board that was mandated to be formed by the 1970 desegregation Court Order and the 1987 desegregation Consent Decree. The purpose of this Committee was to review, on an annual basis, those policies and decisions that directly impacted desegregation such as student transfer and assignment policies; the placement and creation of magnet programs, the criteria for admission into magnet programs; the proposed closing of all schools; the selection of school sites, and the hiring and placement of staff.

Boundary Hearings. The School Board is mandated by Florida law and School Board policy to hold public hearings by the second week in March whenever it intends to 
change the boundaries for schools, which can result in students being bused or attending different schools.

Citizens Concerned About Our Children (CCC). A predominately black, grassroots organization that formed in the spring of 1995 to address issues of racial disparities and inequities in the Broward County School System. Its founding members became the lead spokespersons in the black community on education issues. They filed a lawsuit against the Broward County School Board in 1995 citing inequities in predominately black schools.

Clustering. A desegregation method applied in the 1970 Court Order that called for almost an equal number of white and black students to attend the same school. An example of this is graduating fifth graders from three predominately white and three predominately black schools being assigned to attend sixth grade at one designated middle school.

Consent Decree. The 1987 desegregation agreement between Attorney George Allen and the School Board also referred to as Smith vs. McFatter. McFatter was Superintendent of Broward County schools when the lawsuit was first filed. This Consent Decree became the desegregation blueprint for Broward County from 1987 to 1995.

Daisy Bates Educational Summits. Education conferences sponsored by the National Association for the Advancement of Colored People (NAACP) to analyze and discuss the effects of school desegregation. The Summits were named after Daisy Bates who was President of the NAACP for the state of Arkansas in 1957. She became famous for standing up to Arkansas Governor Faubus when he defied the order of the Supreme 
Court to allow black students into all white Central High School. President Eisenhower intervened by deploying military troops to Little Rock to subdue the white mob and quell the racial disturbance sanctioned by Governor Faubus, which threatened to harm the nine black children that integrated Central High School. This historical event is known as the "Little Rock Nine."

Data sources. This term is used when reporting the findings. It includes the combination of interview sources and archival data sources.

Dual. Denotes a racially segregated school system.

Equity. Fair and just. It does not imply the same treatment or same amount of resources. Equity is based on specific circumstances. Different actions, treatment and resources may be required to make a situation equitable.

Grassroots. Implies the common people. People who are outside the realm of power and influence.

$N A A C P$. National Association for the Advancement of Colored People. This is the oldest black civil rights organization in the United States. It filed the landmark lawsuit Brown vs. Board of Education. The NAACP is the initiator and gatekeeper of school desegregation issues in the United States.

Neocolonizers. A figurative term used to describe the practice of people with power, influence and control over others, handpicking specific people in a community to protect their interests and to represent them in their absence by exercising some element of control or power over the common people.

Pairing. Another desegregation method applied in the 1970 Court Order. A predominately white school and a predominately black school were paired with each 
other. The students in these schools may have been clustered into two or three groups representing different grade levels ( $\mathrm{K}-2$ or 3-5). All the students in the $\mathrm{K}-2$ cluster from both schools may have been assigned to the white school and all the students in the 3-5 cluster may have been assigned to the black school.

Penny sales tax. An initiative by the Broward County School Board in 1995 to raise funds for the building of new schools to relieve overcrowding. Voters in Broward County were asked to approve the levy of a penny sales tax to generate funds for this purpose.

Starbursting. The practice of busing students from highly dense black neighborhoods to numerous schools for the sole purpose of desegregating schools. Starbursting only occurred in black communities.

Student assignment. A procedure, practice and policy of the School System that determines which school a student will attend.

Unitary. A term courts have used to describe a school system that has made the transition from a segregated or racially dual system to a desegregated system.

Summary

School desegregation has been fraught with controversy, strife and conflict since the Supreme Court outlawed segregation in 1954. Broward County was forced to respond to the Supreme Court's order to desegregate schools in 1971 after Attorney George filed a desegregation lawsuit against the School Board. The community's protest against the School Board's desegregation plans began to mount in the mid 1980s, climaxing in the mid 1990s when CCC filed another desegregation lawsuit against the 
School Board. A great deal of animosity between the grassroots community and the School Board was displayed over desegregation polices and practices.

The theoretical models of Russell, Galbraith, and Wartenberg were used to analyze the power relationship between the School Board and the community. This study will contribute to a better understanding of desegregation issues in Broward County and explain how and why certain desegregation policies and practices were developed and implemented. The research also sought to identify those who benefited and won from those policies and those who governed the creation and implementation of desegregation policies and practices in Broward County.

\section{Organization of the Study}

This study is organized into five chapters. The introduction, statement and background of the problem, general statement of the research area, purpose and significance of the study are discussed in Chapter I along with the theoretical perspective, research questions, assumptions of the study, delimitations and limitations of the study, ethical responsibilities, definitions of terms and the summary.

Chapter II provides a historical overview of desegregation in the United States and a chronology of significant desegregation events in Broward County, Florida, from 1970 to 1998 . The chapter also reviews historical case studies of desegregation and literature on the sociological and philosophical understanding of power. The method used in the study is presented in Chapter III, including a rationale for using the historical case study method; a description of methodology, procedures, identification of participants, and a description of the researcher's role. The data and research findings are 
presented in Chapter IV. Chapter V is a summary of the entire study including conclusions and recommendations. Each of the chapters will end with a summary. 


\section{REVIEW OF THE LITERATURE}

This chapter is organized into four sections, which include: literature that gives a historical overview of school desegregation in the United States; a historical overview and chronology of desegregation events of in Broward County, Florida; a review of historical case study dissertations on school desegregation, and an analysis of the concept of power.

Historical Overview of School Desegregation in the United States May 17, 1954, the Supreme Court of the United States rendered a landmark decision commonly known as Brown vs. Topeka, Kansas. This decision stated that stateimposed segregated schools were no longer lawful in this country and that separate educational facilities for black children were inherently unequal (Wiley, 1994).

This decision, by some accounts, ended the United States' racial apartheid policy that had its underpinnings in the 1896 Plessy vs. Ferguson decision. Homer Plessy, a black man, filed a lawsuit against the state of Louisiana for forcing blacks and whites to ride in separate cars on the train. The Supreme Court ruled that racial segregation was not unconstitutional as long as the separate facilities were equal (Wiley, 1994).

During the six-year decade between the Plessy decision and the Brown decision, many lawsuits were filed to undo the "separate but equal" doctrine, which legalized segregation in the United States. Many would argue that the effect that Brown had on the creation of other legislation, i.e., the Civil Rights Act, the Voting Rights Act, and Fair 
Housing was more successful than the results of school desegregation (Wiley, 1994; Orfield \& Yun, 1999).

Brown I was decided in 1954, finding that racial segregation violated the $14^{\text {th }}$ Amendment to the United States Constitution, and that 99 percent of black children in the South attended segregated schools that were unequal and inadequate. A year later in 1955, Brown II ordered schools to desegregate with all deliberate speed. However, it still took a series of state and federal court decisions to force school desegregation.

In 1971 (Swann vs. Charlotte-Mecklenburg), the Supreme Court issued a ruling that desegregation must be achieved in all schools to the greatest extent possible and that busing was an acceptable strategy to accomplish that. This sanctioned the use of increased cross-town busing which gave more impetus to local communities to file lawsuits against school districts that were reluctant to desegregate their schools (Wiley, 1994).

Beginning in the mid 1970s with Milliken vs. Bradley, a downward spiral began to occur with forced busing and desegregation. Federal courts rendered rulings that either relaxed or rescinded desegregation mandates. In the Milliken case the judge refused to order interdistrict busing for purposes of desegregation (Kersten, 1995; Current Issues in Education, 1997; Joondeph, 1998; Orfield \& Yun, 1999).

In the 1991 Dowell case, the Court established that desegregation orders were temporary and could be retired (Dowell vs. Oklahoma, 1991). In Freeman vs. Pitts (1992), the Court ruled that school districts could gradually be released from 
desegregation court orders even if desegregation had not been achieved. In 1995, Missouri vs. Jenkins, the Supreme Court overturned a lower court's decision requiring the school district to invest millions of dollars into magnet programs and desegregation efforts until equity was achieved between black and white students (Orfield \& Yun 1999; Kersten, 1995; Current Issues in Education, 1997). Finally, in September 1999, the ruling responsible for pioneering massive busing to desegregate schools (Swann vs. Meckleburg) was reversed. A federal judge ordered an end to busing in CharlotteMeckleburg after 30 years (Burritt, 1999; Nowell, 1999).

The Influence of Social Science Theories on School Desegregation Decisions

The social science "theory of harm and benefits" played a tremendous role in shaping school desegregation policies in this country. This theory advocated two components. The first is that segregated schools harmed the education and academic achievement of black children by reinforcing negative racial stereotypes and damaging their personal self-esteem. The second was that desegregation benefited the self-esteem, academic achievement, and long-term educational and occupational outcomes for black children while improving race relations for everyone (Armor, 1995).

A sub-component of the harm and benefit theory is the "contact theory" which suggests that interracial contact, under the right conditions, can improve race relations, interracial understanding, reduce prejudice, and increase the self-esteem of black children. In simple terms, the harm and benefit theory postulated that school segregation was harmful to the social, psychological, and educational development of all children, 
black and white, and that school desegregation was an effective way to ameliorate the damages caused by segregation and discrimination.

Gordon Allport, who is known as the progenitor of the "contact theory," used the conceptual framework of social scientists Myrdal and Kenneth and Mamie Clark who had studied desegregation. He postulated that racial prejudice might be reduced if there was no competition for scarce resources, both groups were treated as equal, and if these conditions were supported and sanctioned by authority (Allport, 1953). Contact theory became the primary method embraced by most social scientists to break the vicious cycle of prejudice, discrimination, segregation, and inequality (Armor, 1995).

The earliest most prominent study on the effect of segregation and discrimination against black people was called, An American Dilemma. This study was conducted by a team of social scientists under the leadership of Swedish economist Gunnar Myrdal. This study became known for its "vicious cycle theory" that described the relationship between prejudice, discrimination and inequality. "White prejudice and discrimination keep the Negro low in standards of living, health, education, manners, and morals. This, in its turn, gives support to white prejudice. White prejudice and Negro standards thus mutually cause each other" (Rose, 1956, pp. 27-28). They suggested the reverse of this could also occur. If black people could have their standards raised through better jobs and education, supported by government policies, then white people would look at them and treat them differently. 
An American Dilemma did not study the psychological effects of segregation and discrimination on black people. However, Kenneth and Mamie Clark, a husband-andwife team of psychologists began to conduct studies on black children using dolls to illustrate the negative effect of segregation on the psychological and social development of black children. Their study found that most black children preferred to play with white dolls and associated positive attributes with white dolls and negative attributes with black dolls. The black children also chose white dolls when asked to select the doll that looked like them (Clark, 1939).

When Brown was appealed in 1952, the social science theories of Allport, Myrdal, and Clark were included in and asserted throughout the arguments to the courts. The Brown Supreme Court seemed to have accepted the premises of the social science thesis of harm and benefits.

In 1967, the United States Commission on Civil Rights issued a report entitled Racial Isolation in the Public Schools. It based much of its findings on the data included in a 1966 report conducted by a team of social scientists led by sociologist James

Coleman. This was the first government-sponsored study to conclude specifically that school segregation lowered the educational achievement of black children.

Negro children who attend predominately Negro schools do not achieve as well as other children. Negro and White. Their aspirations are more restricted than those of other children and they do not have as much confidence that they can influence their own futures. When they become adults, they are less likely to participate in the mainstream of American society, and more likely to fear, dislike, and avoid white Americans (U.S. Commission on Civil Rights, 1967, p. 193). 
The Racial Isolation Report appealed to Congress, which passed legislation compelling schools to eliminate racial isolation and to establish a racial balance standard of not more than 50 percent black in any public school (Armor, 1994). The Commission advocated that schools should be considered segregated and inferior when their composition exceeded 50 percent black (Armor, 1994). This precipitated the escalation of litigation and the mandatory busing of students in school districts throughout the country (Armor, 1994).

\section{Pros and Cons of Desegregation}

During the late 1970's and early 1980's school desegregation studies multiplied. Many of the studies contradicted previous findings, conclusions and theories. Some of the new findings concluded that:

Black students in segregated schools did not have serious self-esteem problems. Desegregation had not raised the achievement levels of black students, that desegregation either failed to improve or actually worsened racial attitudes and race relations, and that desegregation was causing white flight and the segregation between cities and suburbs (Armor, 1994, p. 69).

Previous assumptions about the effect of segregation on the self-esteem of black students are also challenged by some social scientists. The doll study has been replicated several times by different researchers with the same results; however, a different interpretation has been offered. A student's preference for a white doll, some researchers say, has less to do with low personal self-esteem and more to do with an evaluation of color. Most studies on self-esteem, since the Clark studies, used direct self-report measures based on interviews or questionnaires. An impressive number of studies on 
self-esteem and desegregation have shown that black students do not suffer from low self-esteem because of being segregated or racially isolated and, in fact, school desegregation may cause low self-esteem for some black students due to prejudice, discrimination, and competition with white students. Some studies show the self-esteem of black students is even higher than that of white students (Rosenberg \& Simmons, 1971; Porter \& Washington, 1979; St. John, 1975; Stephan, 1986).

Rist, in The Invisible Children, asserts that there is much research to support that contact, per se, is not enough and the outcome of the interaction between white and black children depends on the quality of the contact. Rist also reported "Allport himself noted that when the contact was among those of unequal status, and was casual or competitive, it might result in a reinforcement of stereotypes and thus foster further prejudice and a worsening of relations" (1978, p. 5).

Janet Schofield, a psychologist who studies race relations, concluded that the research does not reveal any firm conclusions about the impact of desegregation on intergroup relations (1991).

Many researchers have acknowledged that desegregation has not brought about the expected benefits in race relations and attitude changes, but the reason is not the fault of social science theory. Rather, the fault lies with the designers of desegregation plans including; presumably, courts that order their adoption-who did not create the conditions necessary for successful racial contact (Armor, 1995, p. 106).

Schofield and Sagar raised the issue of power and the unequalness of relationships between white and black students. They indicated that "research shows that even when blacks and whites have similar formal status in a situation and similar background 
characteristics, whites tend to dominate interracial interaction" (Schofield \& Sagar, 1983, p. 94).

Lightfoot also believes that the power relationship between black and white students and between schools, families and communities must be addressed. She cautions that grouping black and white students in the same school while maintaining the same relationships and perceptions is not conducive to a positive learning environment that will cause black children to succeed (Lightfoot, 1980). She also criticizes Brown by saying:

The solutions lacked an awareness of the complex, multifaceted processes of education and negated the strong, enduring, resistive qualities of institutional and cultural inertia. Most important, although the Brown decision focused on schooling, it disregarded the development of children and the perspectives of families and communities (Lightfoot, 1980, p. 4).

The National Institute of Education (NIE), under the auspices of the United States Department of Education (USOE) in 1984, conducted one of the most comprehensive studies on desegregation and black achievement. The NIE assembled a group of six experts on desegregation who held divergent views on the topic, and one expert in research methodology who chaired the group, Thomas Cook. They selected studies already conducted on the relationship between school desegregation and the achievement of black students. The study concluded that desegregation did not negatively affect the achievement of black students, but neither did it have a positive effect in math and just a slight increase in reading levels (Armor, 1994). 
Data were reviewed from the National Assessment of Education Progress (NAEP) comparing the achievement of black students in segregated schools and those in desegregated schools. The data revealed that the gains for black students attending segregated schools were as great as or greater than for black students attending desegregated schools and the gains for black students in disadvantaged urban communities were as great as the gains are for black students in non-disadvantaged communities (Armor, 1994).

Some studies have shown that black children perform better when attending predominately white schools, however, Mahard and Crain caution that black students doing well in predominately white schools has less to do with the whiteness of the school and more to do with their socio-economic status (Mahard and Crain, 1983). Other studies report that when the percentage of white children exceed 80 percent, black children perform poorly (Mahard \& Crain, 1983, 1981). Mahard and Crain concluded, "a school can have too many white students and thus harm black achievement" (1983, p. 124).

Achievement is lower in the schools with the smallest percentage black population. The argument is simply that the overwhelmingly white school is a hostile environment for black students. There are not enough black students and not enough black teachers to provide minority students with the sense of being integrated into the school. The argument would be that they would continue to feel like outsiders, not really a part of the school situation and inhibited in their learning because of this (Mahard \& Crain, 1983, p. 120; 1981, pp. 74, 75).

In 1993, Abt Associates conducted the largest longitudinal study on educational outcomes ever conducted in this country ("The Congressionally Mandated Study," 1993). This study was conducted for the United States Department of Education at the request of 
Congress. Prospects was the name of the study, and it concluded that poor and minority children performed better in predominately middle-class or desegregated schools.

Gary Orfield, Professor of Education and Social Policy at Harvard University and the Director of the Harvard Project on School Desegregation insisted that we must make the distinction between race and class. He stated that it is not necessary for a black child to sit next to a white child in order to learn; however, the reality is that most predominately black and minority schools are also predominately poor. This is not the case with majority white schools, which are usually predominately middle-class. He acknowledges that the fact of black children attending desegregated schools does not in and of itself assure them educational success, but what it does is to provide them with exposure to better opportunities and a more promising peer group (Orfield, \& Yun, 1999).

The Education Trust, a nonprofit research organization, empathetically asserts that poor and minority children can learn and achieve at the same high levels as other children if they are taught at those levels ("Good Teaching Matters," 1998). Their research shows a direct relationship between low standards, low-level curriculum, under-educated teachers and low student achievement. They contend that poor and minority children are not failing because of their socio-economic status or because of the educational level of their parents, but because they are not being taught properly. They cite the teacher as being the most important factor in the equation for the success of poor and minority 
children. They found that poor black children had the least qualified and least competent teachers ("Good Teaching Matters," 1998).

Of all the research conducted on the harm and benefit thesis, the research on longterm outcomes seems to offer the strongest support for desegregation. The extolled benefits of desegregation as cited by Gary Orfield and Willis Hawley (national experts and authors on desegregation) are that black children who have experienced desegregated schools throughout their school life tend to graduate from high school. They tend to have a racially mixed group of friends, attend integrated colleges, live in integrated neighborhoods and work in high status, integrated settings. This is referred to as the "perpetuation theory" which espouses the concept that the major goal of desegregation is to "break the cycle of segregation and allow non-white students access to high-status institutions and the powerful social networks within them" (Wells \& Crain, 1994, p. 531).

\section{School Desegregation Loses Support}

School desegregation, once considered a panacea for hope, upward mobility, economic and social success for African Americans continues to be challenged and questioned. Many people, black and white, seem to share the view that school desegregation has out-lived its intent and usefulness, and perhaps is inappropriate and certainly ineffective as a method to provide quality and equitable educational opportunities for all children. Resignation, despair, and discontent have set in as the disparities between the achievement levels, program placement, suspension, and discipline rates between white and black students and between white and black school 
facilities continue. "Not only has mandatory desegregation failed to produce educational and social benefits for most minority children, but also research shows it can lead to adverse consequences for some" (Armor, 1994, p. 115).

The Public Agenda, which is a nonpartisan, not-for-profit public opinion research organization, conducted a poll regarding people's views toward school desegregation. They interviewed 1,031 adults. Forty-eight percent of blacks and 87 percent of whites agreed that it was better for children to attend their neighborhood schools than be bused to integrate schools (“Race Relations," 1999).

In another Public Agenda poll, 800 white and 800 black parents were interviewed, 80 percent of black parents and 88 percent of white parents said that raising academic standards and achievement was much more important than desegregating schools (“Education," 1998; Jones, 1998).

During the early 1990s a number of newspaper articles appeared around the country reporting on the growing increase in black leaders who were opposed to busing, and instead advocated for resources to be expended on increasing the quality of education in predominately black schools. The mayors and council members from Denver, Seattle, Cleveland, St. Louis, Atlanta, Louisville and Charlotte were mentioned (Kersten, 1995; Eddings, 1997; Wiley, 1994). They criticized busing for placing the burden on black children and in not resulting in closing the achievement gap between black and white children. 
In 1995-96, the national office of the NAACP suspended two local NAACP branch presidents for opposing the busing of black children for desegregation purposes. One of whom was Robert Robinson from Yonkers, New York who alleged that desegregation had outlived its usefulness and accused the NAACP of using the same old out-dated arguments today for desegregation that it used in the 1950s (Joondeph, 1998; Kunen, 1996).

In 1995, the Council of Urban Boards of Education (CUBE) conducted a survey of urban School Board members and administrators. The Council overwhelmingly endorsed the importance of desegregation, however, almost one-third of the Council members said that desegregation had become immaterial in their school districts. Sixty-six percent felt that minority children could receive a quality education in segregated settings given adequate resources and financing. Thirty-one percent of respondents felt that desegregation had actually hurt the educational achievement of minority students.

In 1984, Bruce Hare, a sociology professor at the State University of New York at Stony Brook and Daniel Levine, Professor of Education at the University of Missouri conducted a study at the request of the United States Department of Education regarding the effectiveness of school desegregation. They initially clarified two points. The first point was that the 1954 Brown decision assumed that educational facilities were not equal for white and black children. The second point was that even if they were equal, the effect on black children attending segregated schools was detrimental to them (Hare \& Levine, 1984). 
Hare and Levine (1984) suggested that the assumption that the achievement of black children would automatically rise just because they attended desegregated schools was racist. Supreme Court Justice Clarence Thomas made a similar declaration in his written opinion on Missouri vs. Jenkins. He wrote, "it never ceases to amaze me that the courts are so willing to assume that anything that is predominately black must be inferior." He further implied that it was ludicrous to presume that black children can only learn in an environment if a certain number of white children are present (Cited in Loury, 1997). Figure 1 is the attainment pluralism model created by Hare and Levine.

Box 1 is "lost and alone: ineffective segregated schools." This is undesirable for everyone- those who favor desegregation as well as those who are opposed, which is what the Supreme Court in Brown was most concerned about and wanted to eliminate.

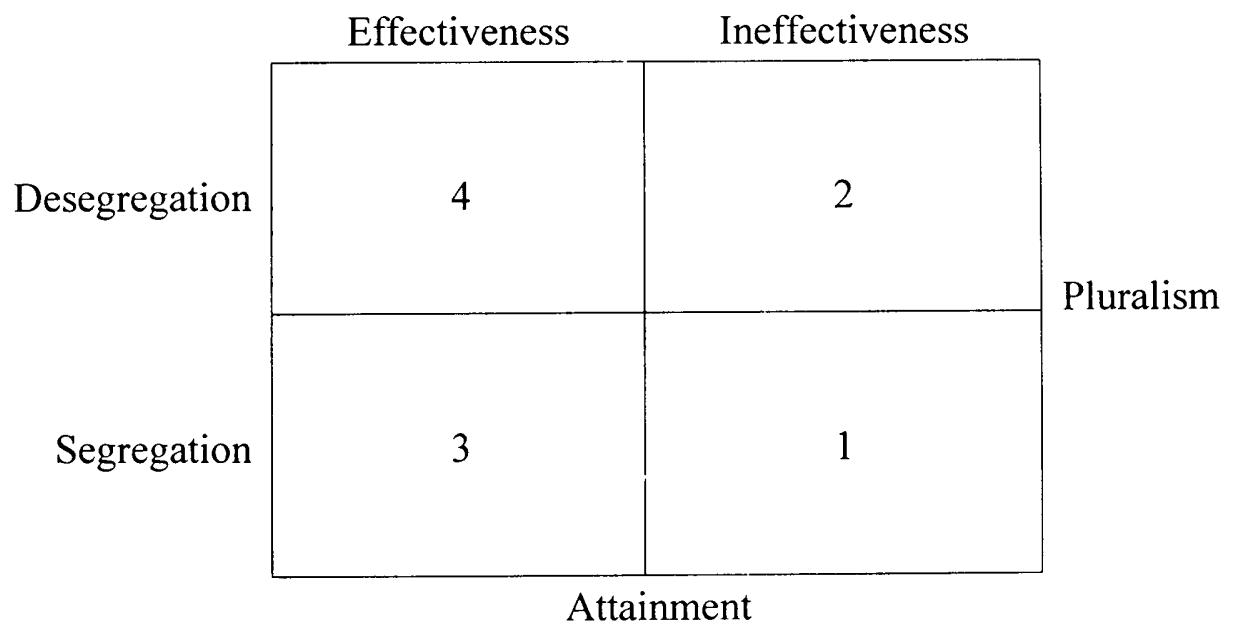

Figure 1. Attainment pluralism model.

Box 2 is the "the blind leading the blind: ineffective desegregated schools." This box represents the controversy surrounding desegregation today. The mixture of white 
and black students has been achieved, but there remains a gulf between the achievement levels of black and white students.

Box 3 is "making academic progress: effective segregated schools." These schools do exist whether by default, design or because it is impossible and/or impractical to desegregate them. Many would argue that while box 4 (effective desegregated schools) are pursued, we cannot afford to sit idly by and do nothing for those children who are stuck in segregated schools. Hare and Levine (1984) admonish that because we have accepted the assumptions that predominately black and minority schools are inherently inferior and ineffective, we have become tolerant of ineffective predominately black and minority schools.

Box 4 is "hitting the mark: effective desegregated schools." This box represents the ideal situation and what most people assumed would be achieved by the Brown Supreme Court ruling. However, because neighborhoods have become increasingly more segregated and public opinion is waning for desegregation, it seems less likely that this is going to occur at any significant level.

In the Harvard Education Letter, Dr. Beverly Cole, Director of Education for the organization that filed the lawsuit that rendered the 1954 landmark decision against segregated schools, the National Association for the Advancement of Colored People (NAACP), was quoted as saying, "we are more concerned with the quality of education and this has to take precedence over whether schools are integrated" (Easton, 1994, p.1). In the same article, Dr. Mary Hoover, Dean of Education, Howard University, 
Washington, D.C., was quoted as saying "recent research says people can learn wherever they are" and that "children might be better off in schools that are not integrated" (Easton, 1994, p.1).

Integration vs. Equity and Equal Access

The grand debate in the black community over desegregation is integration vs.

equal access and quality education. Tony Brown, the host of the PBS television show

"Tony Brown's Journal" has issued strong opinions about desegregation. He insists that:

The rank and file black people fought for desegregation, an end to state-sponsored segregation, and economic and political equality. But the liberals and their sycophants in the black protest movement (mostly lawyers) seduced them with integration, a social elixir that came to be legally interpreted as cultural assimilation into the white community. The result was that blacks who wanted to succeed were compelled to deny their own cultural heritage, to become as white as possible in order to enter the marketplace (Brown, 1995, p. 48).

It (integration) separates upper-strata Blacks from the rank-and-file black. community. It impedes upward mobility by removing role models from the community and eliminating networking opportunities. Integration undermines black advocates of empowerment and marginalizes them as "nationalists" or segregationists (euphemism for anti-white). It forces white leadership upon the black masses through sycophant "black leaders." In short, integration undermines and stunts development in the black community (Brown, 1995, p, 49).

W.E.B. Dubois a Harvard graduate, one of the founders of the NAACP, the original editor of the NAACP's Crisis Magazine, and one of the greatest thinkers of the 20th Century, advised the NAACP against integration. He argued that black people should focus on the educational goal, rather than the means of achieving that goal:

Theoretically, the Negro needs neither segregated schools nor mixed schools. What he needs is education. What he must remember is that there is no magic, either in mixed schools or segregated schools. A mixed school with poor, unsympathetic teachers, with hostile public opinion and no teaching of truth 
concerning black folk, is bad. A segregated school with ignorant placeholders, inadequate equipment, and poor salaries is equally bad. Other things being equal, the mixed school is the broader, more natural basis for the education of all youth. It gives wider contacts; it inspires greater self-confidence; and suppresses the inferiority complex. But other things seldom are equal, and in that case, sympathy, knowledge, and the truth, outweigh all that the mixed school can offer (Dubois, 1935, p. 335).

In 1991, the national office of the NAACP held the first of two school

desegregation conferences called the Daisy Bates Educational Summits. The purpose of these summits was to re-examine the Brown decision and its impact on the educational achievement of black children. It was stated in the summit overview that:

The 1954 Brown decision had brought forth vast changes in society; yet recently, it appeared that the civil rights movement and educational equity, in particular, seemed adrift. On its face, it appeared that Brown plaintiffs were being educated no better than before the decision; that progress in desegregation was elusive, and that because of this, plaintiffs are still restrained from making the political and economic gains envisioned when judicial remedy was sought ("School Desegregation - the Unfinished Agenda," 1991, p.).

The first desegregation summit coincided with the publication of a 1989 document entitled "Resegregation of Public Schools: The Third Generation." School desegregation was divided into three phases: first generation desegregation issues dealt with the physical separation of black children, racial isolation, separate and unequal facilities.

Brown vs. Board of Education really dismantled this practice.

The second-generation desegregation issues became evident in the attitudes, policies, practices and programs of schools. Even when physical integration existed, issues of unequal access to classrooms, teaching bias, ability grouping; disparities in discipline referrals, corporal punishment, suspensions, expulsions and the 
disproportionate number of black children placed in special education, remedial and alternative programs/classes existed ("Resegregation of Public Schools: The Third Generation," 1989).

Patricia Edwards, a senior researcher at the National Center for Teacher Learning at Michigan State University charged that second generation desegregation problems exist because racism in education was never addressed in desegregation policies (Edwards, 1996, p.142).

Eyler, Cook and Ward conducted a study on segregation within desegregated schools. They found that segregation in desegregated schools took the form of black students being disproportionately assigned to various academic programs, i.e., compensatory education, remedial classes, special education, English as a Second Language (ESL) or bilingual classes, and black students being excessively suspended and expelled (Eyler, Cook \& Ward, 1983). They stated that:

While the regular curriculum is organized in ways that lead to resegregation, the tendency for special education programs to become ghettos for black children is even more dramatic. The great disproportionality of black youngsters in special education classes, and particularly in the more stigmatizing EMR (educable mental retarded) classes, has been amply documented (Eyler, Cook, \& Ward, 1983, p. 135).

They further clarified this by saying there is evidence that the placement of black students into special education classes coincides with black students being bused to majority white schools (Eyler, Cook, \& Ward, 1983, p. 137).

The third generation desegregation issues were described as the persistent barriers to integration and equity or the attainment of equal education outcomes ("Resegregation 
of Public Schools: The Third Generation," 1989). It concerns the gap in achievement

between white and black students, the tracking of black students into dead-end classes, the low expectations of teachers, and lack of variation and variety in instructional methods.

Federal Judge Robert Carter, a lead attorney in the Brown case, played a major role in organizing and presenting the social science testimony. He was the General Counsel for the NAACP for many years and one of the key participants in the Daisy Bates Educational Summits. Unlike many other participants in the Brown case, he has publicly admitted to having second thoughts about school desegregation and has expressed dissatisfaction with the results. As noted in the following quote, Carter has reflected that:

Integrated education must not be lost as the ultimate solution. That would be a disaster in my judgment. For the present, however, to focus on integration alone is a luxury only the black middle-class can afford. They have the means to desert the public schools if dissatisfied, can obtain remediation if necessary, and get their children into colleges or some income producing enterprise. The immediate and urgent need of the black urban poor is the attainment, in real life terms and in settings of virtually total black-white school separation, at least if some of the benefits and protection of the constitutional guarantee of equal educational opportunity that Brown requires. The only way to insure that thousands of the black urban poor will have even a remote chance of obtaining the tools needed for them to compete in the marketplace for a decent job and its accompanying benefits is to concentrate on having quality education delivered to the schools these blacks are attending, and in all likelihood will be attending for at least another generation (Carter, 1980, p. 28).

Derrick Bell, a former law professor at Harvard University has taught, lectured and written extensively about civil rights and constitutional law. He was a regular 
participant at the Daisy Bates summits and a critic of desegregation. He insists that black people became the victims in Brown vs. Board of Education.

All the progress that has been made in desegregation depended more on the perceived benefits to whites. And when Brown was won, blacks suffered punishing disproportionate burdens in the implementation of the remedies, including loss of neighborhood schools, displacement of black administrators and teachers, long bus rides for children, and an education that is often worse than the segregated education they received ("School Desegregation - the Unfinished Agenda," 1991, p. 4).

Bell talks about desegregation creating dissonance between the values, styles, and attitudes of parents and educators. He believes that "the interest of blacks in achieving racial equality will be accommodated only when it converges with the interests of whites" (1980, p. 95).

Faltz and Leake (1996) suggested that any real substantive dialogue and analysis of school desegregation have been stymied by three basic assumptions. The first assumption is that desegregation was effective; although there is a lack of any empirical data to back up this claim. They posed two questions that should be asked: (a) who benefits from court-ordered desegregation and (b) has desegregation improved the education of black students?

The second assumption is that black parents are die-hard supporters of desegregation. Initially, black parents were willing to accept the burden of busing and desegregation because they were convinced that their children's educational failure was due to the social and cultural deficits in their own communities. However, they soon 
realized that just because their children attended a predominately white school, there was no guarantee that they would be any better educated than in their neighborhood schools.

Cuddy reported that when black parents in Boston were asked if the same quality of education was provided in their neighborhood schools as provided in suburban schools, would they send their children to their neighborhood schools, $75 \%$ answered affirmatively (Cuddy, 1983).

The third assumption is that a quality education can only be obtained in a desegregated setting.

Inherent in definitions of racial balance are the erroneous assumptions that black children inevitably suffer intellectually when their education occurs in all or predominately black schools and that the motivation and achievement of black children necessarily improve when they are enrolled in majority white schools (Faltz \& Leake, 1996, p. 234).

Hugh Scott, Dean of Education at Hunter College in New York conducted a survey of sixty (60) black school superintendents in 1981. They overwhelmingly agreed that integration offered no guarantee of a quality education for black students and that the major purposes of school desegregation are for equal educational opportunity and quality education for black children (Scott, 1983).

Hawley and Rosenholtz (1986) stated that numerous studies have shown that black and other minority children perform better in desegregated schools than they do in segregated schools. They caution, however, that equity is imperative to quality education and that desegregation alone does not ensure either equity or quality education for minorities. The evidence shows that predominately black and minority schools are less 
likely to get the resources they need to guarantee the achievement of minority students.

They imply that high-performing minority schools are isolated and are the exception rather than the rule.

Adair (1986) conducted a historical study of desegregation in four different cities (Dayton, Los Angeles, Denver and Seattle), and found that each school district reported achievement gains among black students; however, there remained a gap between the achievement levels of white and black students. Adair concluded that:

The focus and scope of desegregation has been limited by practice to the pursuance of racial ratios, not on programmatic and pedagogical issues, or on the pursuit of equity for African American students; therefore neither integration nor equal educational opportunity has been achieved in any of the four cities (p. 346).

Adair (1986) further elaborated that the school boards of the four respective districts were more concerned about meeting the mandates of the courts rather than the demands and concerns of the black community for equal access to quality programs and effective learning and environment. As a result, the black community ceased to support the idea and practice of desegregation.

Historical Overview of Desegregation in Broward County, Florida

For two decades, the community and the School Board of Broward County, Florida have been at odds with each other over school desegregation. Not only were these two entities in opposition to each other regarding the policies and practices of desegregation, but there were also varying factions in the community on opposite sides of the issue. As the antagonism grew, the support for school desegregation decreased (Work, 1991a, 1991b, 1992). 
The controversy over school desegregation in Broward County reflected the discussions that were taking place in other parts of the United States. The persons involved in the dispute seemed to be divided into two groups: proponents of the social science theories of harm and benefits, contact theory, and vicious cycle theory and those that pushed for equity and equal access.

Some black and white parents were saying their children were being used, discriminated against and exploited by the School Board's desegregation policies and practices without their children really benefiting, while most white parents refused to have their children bused for purposes of desegregation ("NAACP Pushes Fight,"1991; Payne, 1991; "Schools and Desegregation," 1991; Work, 1991a).

As the ethnic and cultural population of blacks in Broward County began to change, the support for busing black children out of their neighborhoods to predominately white schools to achieve desegregation began to decline. Many of the black parents from predominately black countries in the Caribbean and Africa had a hard time understanding why their children could not receive a good, quality education in their predominately black neighborhood schools (Boursiquot, 1994). After all, they came from countries with student bodies and school staff often times 100 percent black.

The Broward County Schools Board's desegregation policies and practices were primarily based on the tenets of the Racial. Isolation Report (1990) that said schools over $50 \%$ black were segregated and inferior. This report was based on Allport's contact theory that promoted black children interacting with white children in a controlled 
environment as a means to improve their self esteem, social skills and ultimately academic and educational achievement.

Gary Orfield reports that school desegregation began a downward spiral in the late 1980s after a 25 -year trend of increasing school desegregation. He reported that in 1996, black students attending predominately white schools in the South fell below the level actually achieved 24 years earlier. Broward County is credited with making Florida one of the states with the largest increase in reverse desegregation (Orfield \& Yun, 1999).

There were obvious power struggles between the School System of Broward County and the grassroots community regarding school desegregation issues. These power struggles are revealed in the chronology of events below. Power techniques used by both the School System and the grassroots community to influence desegregation decisions are embedded in the chronology of events, however, they are specifically identified by the data sources and are disclosed in the Findings in Chapter IV.

Historical Chronology of Desegregation Events in Broward County, Florida 1970 Broward County Schools - Desegregation Court Order

In January 1970, Attorney George Allen filed a lawsuit against the Broward County, Florida School Board on behalf of his two children and the NAACP. The basis for the lawsuit was that the School Board operated a dual system and was in violation of Brown vs. Board of Education that deemed separate educational facilities inherently unequal (Allen vs. Broward County, 1979). 
In April 1970 a final Court Order was signed by the Judge that found the Broward County School Board guilty of operating a dual School System and ordered it to implement changes to bring it into compliance with a unitary system. The plan called for the closing of one of the three black high schools, and all the junior high schools; turning junior high schools into middle schools; the pairing and clustering of schools and boundary changes that required busing. In every school, black teachers were to reflect at least the ratio of the black population in the County. The district would initiate an aggressive program to recruit and train black people for administrative positions (Allen vs. Broward County, 1979). The Order gave the Court jurisdiction to oversee the School Board's efforts to implement a comprehensive desegregation plan.

In June 1979 the Court entered an Order declaring that the School Board's Desegregation Plan, as adopted by prior Orders of the Court, "constituted a unitary school system in accordance with the U.S. Constitution" (Washington vs. Broward County, 1995a). On July 31, 1979, Judge Eaton relinquished jurisdiction over the case. He wrote "eight years have passed since the entry of the final Order," (Allen vs. Broward County, 1979) and implied that since neither the School Board nor the plaintiff Attorney George Allen, had appealed any of the previous Orders of (Aug. 18, Sept. 4, 1970 or June 21, 1971), they obviously did not object to the Orders; therefore, he found no further judicial action necessary.

Ten years later on August 25, 1989, School Board attorney, Ed Marko, sent a memo (personal communication) to School Board members updating them on two 
lawsuits filed by white parents who requested the Court grant preliminary injunction in the form of maintaining existing school boundaries instead of forcing their children to be bused to neighboring black schools. Judge Edward Davis ruled in favor of the School Board and stated that his conclusions were based upon the law and the evidence of the Broward County School System already having been established unitary.

It is not clear when the desegregation plan was changed, but according to a memo from School Board Attorney Marko to School Board members: between 1970 and 1978, the School Board modified boundaries that eliminated pairing and clustering (Marko, personal communication, March 21, 1989). This is significant because the pairing and clustering method for desegregating schools was an approach that was fairly racially equitable. It appears that without the knowledge and consent of the Court, the School Board instituted a plan of busing designed especially for the black community called "starbursting" that would later be contested in court and bitterly protested by the community.

\section{Consent Decree}

In February 1983, Attorney George Allen filed his second desegregation lawsuit on behalf of Ray Smith who served as First Vice-president for the Fort Lauderdale, Florida NAACP. Allen charged the School Board in the original complaint with practicing racial and ethnic discrimination and segregation. He complained that the School Board failed to maintain and upgrade schools in predominately black neighborhoods. It failed to comply with the 1970 and 1971 Court Orders and to hire 
black professional staff. He also complained about the building of new schools in predominately white neighborhoods that had no or few black students, for closing black schools and ending pairing and clustering (Smith vs. McFatter, 1983, 1987).

Ray Smith's rationale for filing the lawsuit was the following: He lived in Lauderhill, a middle-class community in Broward County, Florida that had transitioned from being predominately white to becoming predominately black. When this community was predominately white the School Board created boundaries that bused the children from this community into neighboring predominately black schools. Smith had one son being bused to predominately black Lauderdale Lakes Middle and another son being bused to predominately black Oriole Elementary. Neither of his children or the other children in that community was allowed to attend their neighborhood school that was within walking distance. He argued with the School Board that if his children were to attend a predominately black school, why not allow them to attend the predominately black school in their own neighborhood instead of busing them out to predominately black schools (Williams, 1993).

This was not an isolated or unusual case or scenario in Broward County: black children not being allowed to attend their own neighborhood schools and instead being forcibly bused to other predominately black schools (Banker, 1995f). Smith argued that the School Board had become so intractable and rigid in its policies, practices and procedures that it was beyond reason (Williams, 1993). 
In an April 2, 1991 internal School Board memo (personal communication) from Art Wittman (a demographer for the School Board) to William Dandy (Deputy Superintendent), it was revealed that for the 1990-91 school year, 9,693 black students were bused for purposes of desegregation as opposed to 3,434 white students. Of that number, 2,300 of those black students were bused to schools that were predominately black.

In April 1987, a Court Order Settlement Agreement was entered into between Attorney George Allen and the School Board of Broward County. It became the target of much criticism and retribution in the black community. George Allen was criticized for "selling out" black children and the black community (Pugh, 1992).

The final settlement agreement did not seem to reflect the concerns listed in the original complaint for injunction (Smith vs. McFatter, 1983, 1987). There seemed to be mutual concern and consensus in the black community and with state and national NAACP officials and civil rights attorneys that the emphasis of the settlement agreement appeared to switch from concerns about children, fairness and equity to the hiring and promotion of more black people, particularly into administrative positions and to voluntary desegregation for white students via magnet programs.

This plan (Consent Decree) resembled what is commonly referred to as the "Atlanta Compromise." In 1973, the national NAACP office admonished the Atlanta, Georgia branch of the NAACP for adopting a school desegregation plan that provided minimally for desegregation. The plan called for the mass busing of black children in 
exchange for the hiring of fifty percent black administrators ("NAACP Suspends Atlanta Unit," 1973).

There was an ongoing attempt by the two NAACP branches in Broward County (Fort Lauderdale and North Broward), in conjunction with state, regional and national NAACP offices to undo this desegregation Consent Decree and to replace it with one that was more comprehensive and aggressive in addressing issues of inequity (Marks, 1991c; Work, 1992).

1995 Desegregation Task Force Report

The School Board is required by state law and district policy to hold public hearings prior to changing the attendance zones or boundaries of schools. Changing attendance zones usually involved the busing and/or reassignment of students to different schools. There is no other issue in the Broward County School System that has caused more tension and political vulnerability for School Board members, acrimony and divisiveness between black and white communities than this issue.

In 1993, following a very long, nasty and volatile school boundary hearing, school Superintendent "Sam" Morgan was ordered by School Board members to create a better, more congenial process for addressing boundary (busing) issues. Mr. Morgan proceeded to create the Superintendent's Desegregation Task Force that came into actual existence under the auspices of the next school Superintendent, Dr. Frank Petruzielo (Washington \& Waldman, 1994). The School Board hired as its consultants, Hogan \& Hartson, a law 
firm out of Washington, D.C. that specializes in school desegregation (Hogan \& Hartson, personal communication, January 27, 1994).

The Desegregation Task Force consisted of 16 members. The Superintendent and each of the seven School Board members appointed two representatives. Seven subcommittees were formed, each representing a particular vestige of segregation (student assignment/busing, student achievement, faculty/staff, facilities, extracurricular activities, magnet programs, and transportation). Participation on the sub-committees was open to the general public, which allowed for a more balanced representation of people from various ethnic, racial, and socio-economic backgrounds. Various School Board staff persons were assigned to each of the sub-committees to provide information, technical assistance and support (Washington \& Waldman, 1994).

The role of the Task Force was to identify vestiges of racial segregation in the Broward County School System, make recommendations for remediation and to make a preliminary determination about whether the School System was unitary (Washington \& Waldman, 1994).

"Unitary" is a term courts use to describe a school system that has made the transition from a segregated or "racially dual" system to a desegregated or "unitary" system. This was defined in a January 27, 1994 letter from attorneys Hogan \& Hartson (personal communication).

The January 27,1994 letter, also explained that Green vs. New Kent County School Board in 1968, first established that racial identification (discrimination) must be 
eliminated in six different areas for a school system to be considered unitary: student body, faculty, staff, transportation, extra-curricular activities and facilities. Until the 1991, United States Supreme Court decision in Dowell vs. Oklahoma (1991), many lower courts had divergent opinions regarding what constituted a unitary school system and the procedures for making such a determination. In Dowell the Supreme Court made explicit reference to the six factors in the Green case and made it clear that the District Court must issue a precise statement to that effect (Dowell vs. Oklahoma, 1991). Before such a pronouncement is made, the Court must conduct an evidentiary hearing and determine the following:

1. That the school district has complied in good faith with the court's desegregation orders.

2. That the district has done everything practicable to eliminate the vestiges of segregation from every facet of the school system.

3. That the district's good faith commitment to desegregation makes it unlikely that it will return to its former desegregative practices.

The January 27, 1994 letter, further explained that following the 1968 ruling in the Green (1968) case which established the six different discrimination factors; subsequent indicators were later added. In Milliken vs. Bradley (1977), the Supreme Court recognized educational deficiencies as a contributing factor to segregation. In Freeman vs. Pitts (1992), the Supreme Court reinforced the notion that educational 
quality was a possible factor that could be considered in determining the unitary status of a school system.

The Desegregation Task Force rendered a final report in January 1995, after meeting for 18 months. The consultants (Hogan \& Hartson) said that was the most thorough and comprehensive desegregation report they had ever seen.

The findings in the report suggested that the Broward County School System was not unitary because there were gross inequities in all seven areas studied (student achievement, student assignment/busing, magnet programs, transportation, faculty/staff, extra curricular activities and facilities). Very specific recommendations were offered in the report to remediate the inequities (School Board of Broward County, 1995).

During the course of the Task Force meetings there was ongoing collaboration and meetings with the Superintendent. As the various sub-committees completed reports, meetings were held with the Superintendent to discuss them. Sometimes agreement was reached on modifications, sometimes not. The major point of contention between the Superintendent, School Board and the Desegregation Task Force centered on the recommendations made by the student assignment sub-committee that dealt with busing and school boundaries.

A major recommendation made in the Task Force report was for the School Board to petition the Court for a status of declaration of unitariness, even though, its findings indicated the School System was far from being unitary. This was a strategic move, an effort to get the School Board and the community from under the 1987 Consent Decree 
which was considered by many in the community to be unproductive, ineffective, punitive and politically formulated. The School Board attorney and the Superintendent adamantly opposed this recommendation.

The final Task Force report made to the School Board for approval was in January 1995. This was a couple of months before the annual boundary hearings began and after some of the black members on the Task Force met with the Superintendent to elicit his support for the recommendations from the student assignment sub-committee. They warned him that if he and the School Board did not make some substantial changes to equalize the busing of black and white children, end the starbursting of black children, and stop the practice of denying black children access into magnet programs they would seek retribution (CCC, personal communication, January 13, 1994).

The members of the Desegregation Task Force were angry and disappointed about the reaction of the Superintendent to the recommendations from the Task Force. They reported that he considered the recommendations to be too impractical and a threat to his authority and to the authority of the School Board. School Board members seemed conciliatory, but passive on the issue. The Superintendent later presented a modified plan to School Board members that they ratified. The plan was considered a weakened version of the plan originally submitted by the Desegregation Task Force (Banker \& Hirschman, 1995; "Citizens Concerned About Our Children Speak Out," 1995; Kiffin, 1995e, 1995f; Marks, 1995d, 1995e). 
The African Americans participating on the Desegregation Task Force reasoned that they had more to lose than anyone else did and felt betrayed and humiliated by the School Board and the process. Following the School Board meeting, they gathered in the lobby of the School Board headquarters and decided to mount a grassroots campaign against the School Board to force the redress of the inequities unveiled in the Desegregation Task Force's report. Citizens Concerned About Our Children (CCC) was formed on that day, at that very moment (Talalay, 1999).

CCC claimed that the School Board's response to its demands was to operationalize a powerful political machinery inside and outside the School System to neutralize, discredit and defeat $\mathrm{CCC}$ as an organization, as well as its individual members and its allies ("Black Leaders Wanted," 1998; Citizens Concerned About Our Children, 2000a, 2000b).

May 1995 - George Allen Relinquishes Control

George Allen had been the chief spokesperson in the black community on school desegregation for 25 years. CCC alleged that the School Board made no decisions regarding student assignments (busing), the building of new schools, closing of schools, changing attendance boundaries, magnet programs or the creation of new administrative positions without consulting him. According to different newspaper articles, CCC suggested that this imbued him with tremendous power and that this made him one of the most powerful and influential people in Broward County. Even though Mr. Allen was the attorney for a sole client (Ray Smith), his interpretation and opinions regarding the 
Consent Decree and school desegregation affected the entire Broward County

community. However, he was criticized for not consulting with the community. Many people, black and white, felt that Mr. Allen held the community hostage by virtue of the power the courts and the School Board had vested in him as the guardian and watchdog over school desegregation (Alexander, 1995; Banker, 1995a, 1995c, 1995d; Banker \& Williams, 1995; "Black Leaders Wanted," 1998; Clayborne 1995b; "Fresh Eyes," 1995; Hirschman, 1995; Marks, 1995a, 1995b, 1995c; "New Era Begins," 1995; Work, 1995).

CCC led the black community in ridiculing George Allen, depicting him as a traitor to black children and an exploiter of the black cause. He was attacked for distancing himself from the lower socio-economic black community who was most adversely affected by starbursting and School Board policies and practices based on the Consent Decree, which he helped to craft (Alexander, 1995; Banker 1995e; "Black Parents," 1995; "Black Leaders Wanted," 1998; Citizens Concerned About Our Children, 1996; Clayborne, 1995a; Price, 1995a; "The Spook Who Sat," 1995;). The discord in the black community seemed to be based on socio-economic status. The issues that $\mathrm{CCC}$ raised were issues that pertained to schools located mainly in predominately poor black neighborhoods that affected mostly poor black children.

Three months before George Allen withdrew from the case, he and the School Board attorney appeared before Federal Judge Kenneth Ryskamp to request $\$ 4,000$ in attorney's fees. Attorney Allen purportedly gave the judge the impression that everything was well and good in the black community concerning desegregation (Banker, 
1995f; "Black Children are Being Used," 1995; "Black Leaders Wanted," 1998;

Clayborne, 1995a). This seemed consistent with Attorney Allen's reluctance over the years to respond to the community's concerns and the community's discontent with the Consent Decree and inequities in the School System (Price, 1995a). At one point, the Judge questioned whether Attorney Allen really represented the black community (Smith vs. McFatter, 1995; Clayborne, 1995a).

The black community with CCC's leadership created so much public criticism, scrutiny and furor around Mr. Allen and the Consent Decree, that the plaintiff, Ray Smith, in a May 5, 1995 newspaper article began to renege and to question his attorney's (George Allen) leadership on the issue of school desegregation (Banker \& Williams, 1995). That same week Mr. Allen withdrew from the Ray Smith case and three young black attorneys took over (Alexander, 1995; Banker, 1995f; Marks, 1995c; "New Era Begins," 1995). There was much animosity and bitterness expressed among Mr. Allen, CCC and supporters on both sides. The implications of this went far beyond education. It marked the beginning of a paradigm shift in the power structure in the black community and the black community's relationship with the dominant white community.

Under the 1987 Consent Decree, the percentage of integrated high schools and elementary schools decreased by 50 percent since 1973 . The percentage of integrated middle schools decreased from 91 percent in 1973 to 32 percent in 1994, as shown in Table 1. 
Table 1

Racially Identifiable Schools

Year

Schools

\begin{tabular}{|c|c|c|c|c|c|c|}
\hline 1968 & \multicolumn{2}{|c|}{1973} & \multicolumn{2}{|c|}{1983} & \multicolumn{2}{|c|}{1994} \\
\hline$n \quad \%$ & $n$ & $\%$ & $n$ & $\%$ & $n$ & $\%$ \\
\hline
\end{tabular}

Elementary schools

\begin{tabular}{|c|c|c|c|c|c|c|c|}
\hline Integrated ${ }^{1}$ & 4 & 6 & 58 & 64 & 41 & 42 & 38 \\
\hline Racially identifiable ${ }^{2}$ & 68 & 93 & 15 & 16 & 36 & 37 & 43 \\
\hline Other ${ }^{3}$ & 1 & 1 & 18 & 20 & 20 & 21 & 35 \\
\hline Total & 73 & 100 & 91 & 100 & 97 & 100 & 116 \\
\hline
\end{tabular}

Middle schools

Integrated $^{1}$

Racially identifiable ${ }^{2}$

Other $^{3}$

$\begin{array}{cccccccc}5 & 31 & 21 & 91 & 13 & 46 & 10 & 32 \\ 10 & 63 & 2 & 9 & 9 & 32 & 7 & 23 \\ 1 & 6 & 0 & 0 & 6 & 21 & 14 & 45 \\ 16 & 100 & 23 & 100 & 28 & 100 & 31 & 100\end{array}$

High schools

Integrated

Racially identifiable ${ }^{2}$

Other $^{3}$

$\begin{array}{rcccccrc}6 & 55 & 16 & 89 & 15 & 68 & 10 & 45 \\ 5 & 45 & 1 & 6 & 4 & 18 & 4 & 18 \\ 0 & 0 & 1 & 6 & 3 & 14 & 8 & 36 \\ 11 & 100 & 18 & 100 & 22 & 100 & 22 & 100\end{array}$

Total

11100

$18 \quad 100$

Note. From Desegregation Task Force Report. (1995, January). School Board of Broward County, FL.

'Integrated $=$ schools where the enrollment was $+/-15 \%$ of the County average black population.

${ }^{2}$ Racially Identifiable $=$ schools where the enrollment was greater than or equal to $90 \%$ black or greater than or equal to $90 \%$ white.

${ }^{3}$ Other $=$ not integrated or racially identifiable.

In 1995, ninety-one percent of children being bused for purposes of racial

desegregation were black (School Board of Broward County, 1995). Black children were 
bused west across State Road 7 (Route 441) and University Drive, but hardly any children were bused east of those roads. Not one child was forcibly bused out of the predominately white, middle class and affluent communities of Coral Springs, Parkland, Weston, Cooper City, Miramar, and Pembroke Pines, though black students were bused into those communities (Citizens Concerned About Our Children, 1995b; "Schools and Segregation," 1991; Woodall, 1989).

Table 2 shows that thirty-eight new elementary schools opened since the 1970-71 desegregation Court Order. A sum of nine percent black students was assigned to those new schools (School Board of Broward County, 1995).

Starbursting was a form of busing and assigning students to schools that was only applied to black children and the black community. It is not clear exactly when and who started starbursting. There was indication in a letter from the School Board attorney to the chairperson of the School Board in 1989 that starbursting was initiated between 1970 and 1978 (Marko, personal communication, March 21, 1989; Woodall, 1989).

Oral sources have implied that starbursting was the creation of a black "power broker" to ensure the compliance of the Broward County School System with the desegregation Court Order. The reason given is because white families began to relocate to extreme western communities and those that remained refused to participate in the pairing and clustering of schools outlined in the 1970 school desegregation Court Order (Woodall, 1989). 
Table 2

Elementary Schools Opened Since 1970 Desegregation Court Order

\begin{tabular}{|c|c|c|c|}
\hline Year opened & $\begin{array}{c}\text { Administrative } \\
\text { areas }^{1}\end{array}$ & $\begin{array}{l}\text { Number } \\
\text { of } \\
\text { schools }\end{array}$ & $\begin{array}{c}\text { Percentage of } \\
\text { black students } \\
\text { when school opened }\end{array}$ \\
\hline \multirow[t]{3}{*}{$1970-71$} & $\mathrm{C}$ & 2 & 41 \\
\hline & $\mathrm{N}$ & 1 & 0 \\
\hline & $\mathrm{S}$ & 1 & 0 \\
\hline $1972-73$ & $\mathrm{~N}$ & 1 & 8 \\
\hline \multirow[t]{3}{*}{$1973-74$} & $\mathrm{C}$ & 1 & 13 \\
\hline & $\mathrm{N}$ & 2 & 38 \\
\hline & $\mathrm{S}$ & 1 & 0 \\
\hline $1974-75$ & $\mathrm{~N}$ & 2 & 27 \\
\hline \multirow{3}{*}{$1975-76$} & $\mathrm{C}$ & 1 & 20 \\
\hline & $\mathrm{N}$ & 2 & 17 \\
\hline & $\mathrm{S}$ & 1 & 1 \\
\hline $1977-78$ & $\mathrm{~N}$ & 1 & 2 \\
\hline $1978-79$ & $\mathrm{~S}$ & 1 & 2 \\
\hline \multirow[t]{3}{*}{$1979-80$} & $\mathrm{C}$ & 1 & 1 \\
\hline & $\mathrm{N}$ & 1 & 1 \\
\hline & $\mathrm{S}$ & 1 & 2 \\
\hline $1980-81$ & $\mathrm{~N}$ & 1 & 0 \\
\hline \multirow[t]{4}{*}{$1986-87$} & $\mathrm{C}$ & 1 & 5 \\
\hline & $\mathrm{N}$ & 1 & 1 \\
\hline & $\mathrm{N}$ & 1 & 2 \\
\hline & $\mathrm{S}$ & 2 & 2 \\
\hline \multirow[t]{2}{*}{$1989-90$} & $\mathrm{C}$ & 1 & 3 \\
\hline & $\mathrm{N}$ & 3 & 32 \\
\hline $1990-91$ & $\mathrm{~S}$ & 2 & 25 \\
\hline 1991-92 & $\mathrm{N}$ & 1 & 37 \\
\hline $1992-93$ & $\mathrm{C}$ & 2 & 16 \\
\hline 1993-94 & $\mathrm{N}$ & 1 & 1 \\
\hline \multirow[t]{2}{*}{$1994-95$} & $\mathrm{C}$ & 1 & 34 \\
\hline & $\mathrm{S}$ & 1 & 3 \\
\hline
\end{tabular}

Note. $\quad{ }^{\prime} \mathrm{C}=$ Central, $\mathrm{N}=$ North and $\mathrm{S}=$ South. ${ }^{2}$ Indicates the average number of black students for all schools in area for that particular year. From Desegregation Task Force Report. School Board of Broward County, Florida (1995). 
Also, the 1970 final judgment had already indicated that the Court did not consider it feasible or practical to force desegregation upon students who lived in remote and distant areas (mostly white) and that it would be almost impossible to desegregate schools in highly dense black communities (Allen vs. Broward County, 1979). Therefore, the burden of busing was placed on black children and the black community. School districts throughout the country had desegregation plans similar to Broward County's plan. Milwaukee is an example. In 1990, a task force similar to the Broward Desegregation Task Force was formed to look at the achievement of black males in Milwaukee. The findings and issues raised by this task force were similar to Broward's. More than 80 percent of the 5,716 black males in high school had less than a 2.0 GPA. Even though black males made up only 27.6 percent of the district's student population, they accounted for $50 \%$ of the suspensions and $94 \%$ of expulsions. The average GPA for black freshmen students in six of the 10 high schools was below 1.0. The average grade for all black students was $D$, between $27 \%$ and $60 \%$ of the grades for all black freshmen was $F$. Eighty percent of black students in the district were being bused for purposes of desegregation. The black community was sliced up and the students dispersed to many different schools. The black community complained that the busing plan was responsible for the loss of a sense of community and neighborhood identification, alienation of black youth, and made it difficult for parents to get involved in their children's schools (Faltz \& Leake, 1996).

After nearly 20 years of implementing busing as a strategy to achieve desegregation in Milwaukee, the expected achievement gains for black children 
have not been realized. The paradox is that the very process designed to facilitate the desired educational benefits has undermined the nurturing environment necessary for such achievement (Faltz \& Leaky, 1996, p. 248).

Hence, the black community called for an end to the massive busing of black children and the creation of African-American Immersion Schools to raise the achievement level of black males and to create a sense of community again.

Like the black community in Milwaukee, $\mathrm{CCC}$ and many in the black community in Broward felt betrayed by the School Board's desegregation plan and demanded an end to the massive busing of black students. CCC deliberately depicted starbursting as evil, immoral, unfair, unjust and a form of institutionalized racism (CCC flyer, personal communication). CCC launched a major public relations campaign against the School System and its practice of starbursting. In newspaper articles and flyers written by CCC, it was stated that when white parents refused to send their children to black schools or to school with black children the School Board created starbursting, the one way busing of black children in order to satisfy the desegregation Court Order (CCC, personal communication, January 31, 1994).

Densely populated black communities (most not over a two-mile radius) were identified by the School Board and used as desegregation warehouses. Elementary school children living in those communities were bused out to several schools. It was not uncommon for children living in those communities to be assigned to numerous schools outside their communities as shown in Table 3. The impact was that children living on one side of the street would attend one school; those on the other side of the street would 
Table 3

Number of Elementary Schools to which Students were Bused in Starbursted Communities

Starbursted

communities

Number

Broward Estates

6

Carver Ranches

6

Dillard

7

Drew

4

Martin Luther King

6

Sanders Park

7

Sunland Park

6

Walker

6

Note. From the Desegregation Task Force Report. (1995 January). School Board of Broward County, FL.

attend another school. Children on the next block would attend yet a different school (CCC, personal communication, January 31, 1994; Peterman, 1995).

At public hearings held by the Desegregation Task Force as well as at School Board boundary hearings, parents and community activists expressed what they called the horrors of starbursting (Arthur \& Marks, 1995a; Banker, 1995b, 1995d; Clayborne 1995c; Price, 1995c). Many of the schools the children were bused to were five to ten miles away from their homes. It was argued that parents did not have transportation to visit the schools for conferences, meetings or to pick up their children when ill. Parents had difficulty accessing before and after school child care. Students could not participate 
in extracurricular activities because they had no transportation home. Starbursting created dissension, divisiveness, rivalry and lack of cohesion and community spirit in the neighborhoods, because the children could not share a common school experience. They could not study together or share school resources. Starbursting resulted in the under enrollment of black schools causing some of them to be closed and contributed to a high student mobility rate that is positively correlated with poor student achievement (CCC flyer, personal communication).

The Superintendent and School Board members refused to make changes satisfactory to members of the Desegregation Task Force (Banker, 1995d, 1995f; Banker \& Hirschman 1995; Brown, 1995; Kiffin, 1995c, 1995d, 1995e, 1995f). Boundary hearings began and so did grassroots organizing, coalition building and networking across racial, ethnic and socio-economic lines. For the first time in the history of Broward County, black and white parents, students and community people coalesced in large numbers in a common cause against the School Board and to attend the boundary hearings over a three-month period. Churches and community organizations brought people by the busloads. CCC members organized the black community around this issue, were present and spoke at every boundary hearing (Banker, 1995b; "Black Leaders Wanted," 1998; Citizens Concerned About Our Children, 2000a; Kiffin, 1995g). Members of CCC and their coalition movement became so incensed at the attitudes and conduct of the Superintendent and School Board members toward them and this issue, they promised retribution. They told the School Board and the Superintendent 
unequivocally that if they did not vote to end starbursting and create a policy against the use of starbursting as a desegregation tool they would oppose the "penny sales tax" that the School Board desperately wanted and needed to build new schools to relieve overcrowding ("Blacks Will Mount," 1995; Kennedy, 1995; Kiffin, 1995b; Marks, 1995e; "The Spook Who Sat," 1995). The penny sales tax was subsequently defeated by a seven to one margin (Arthur \& Marks, 1995b; Clayborne, 1995b; Nevins, 1995; Tax Initiative Suffers, 1995).

June 1995 - CCC Files Lawsuit against Broward County School Board

Following the School Board's refusal to accept the full recommendations from the Desegregation Task Force to remediate the inequities identified in its 18 month inquiry and the School Board's unwillingness to equalize the busing of black and white children and end starbursting, CCC filed a lawsuit (Banker, 1995a; Kiffin, 1995a). The parties to the lawsuit were CCC, and two anonymous children of CCC members (Kiffin, 1995a).

The lawsuit addressed not only busing and boundaries, but access to magnet programs, unequal facilities, curriculum and course offerings, materials, supplies, faculty and staff issues, in predominately black schools.

August 1995 - Ruling on Washington Case, Unitary Status

Judge Kenneth Ryskamp issued a Court Order declaring the Broward County School System to be unitary. This order was based on a lawsuit filed in 1992, by a group of white, upper-middle class parents living in eastern Broward County who contested 
changing the boundaries of their children's middle school for the purpose of desegregating the School System.

The parents protested to the School Board and argued against the unfairness of the burden of busing and desegregation mainly in eastern communities (Arthur \& Marks, 1995a; Banker, 1995b, 1995d; Clayborne, 1995c; Kiffin, 1995d). It was common knowledge that many white parents chose to move as far west as possible because the School Board did not bus students from western communities to integrate predominately black schools located in the east.

The School Board and many in the black community labeled the parents in the Washington case racists; alleging they did not wish their children to attend Rogers Middle School because it was predominately black. The parents made the counterargument of protesting the boundary changes because they wanted their children to attend the same school with their peers throughout their school career and not because they were racists. In that way they could better monitor and control their children's peer group and socializing activities (Fernandez, 1992).

Over the years there had been increasing tension between white parents in the east and white parents in the western parts of Broward County. Whenever the School Board attempted to appease the black community by busing white children, it always selected those white communities in closest proximity to black communities. These were usually low to moderate income white communities, with little sophistication, limited education and resources, or political clout. In this case the School Board chose to change the 
boundaries for the middle school that affected a group of upper middle-class and affluent students with professional, sophisticated and politically astute parents.

The attorney for this group of parents later became the attorney for $\mathrm{CCC}$. $\mathrm{He}$ argued that the School Board was in violation when assigning children to schools based on race because the Broward County School System was deemed unitary in 1971, therefore was restricted from making any race based decisions (Banker, 1995a; Washington vs. Broward County, 1995a).

The Court supported the evidence presented by the plaintiffs. The judge wrote:

In June of 1971, Judge Cabot, then presiding over the matter of Allen vs. Board of Public Instruction, Broward County, Florida, 329 F. Supp. 251 (S.D. Fla. 1971), entered an Order pursuant to direction and recommendation from the Fifth Circuit with respect to the pending desegregation suit. In that Order, the Court "conclude[ed] and declare[ed] that the Broward County School Desegregation Plan as adopted by orders of the Court of April 30, August 28, and September 4, 1970 , and this Order, constitutes a unitary school system in accordance with the United States Constitution."

In summary, the Court finds that there is no genuine issue of material fact that Judge Cabot's unappealed 1971 Order and Judge Eaton's unappealed 1979 decision to relinquish jurisdiction over the School Board together constitutes a clear and binding declaration by this Court that the Broward County School System has attained full unitary status as of 1979. Because there is no evidence that Broward County's School System ever lost its unitary status, the Court finds that the school system was unitary when plaintiff instituted their action in 1992 and remains so this day (Washington vs. Broward County, 1995a).

Evidence was provided to the judge indicating that the School Board attorney utilized and conferred unitary status when politically convenient. When it was not politically convenient the School Board attorney with the support of Attorney George Allen would insist on the School Board maintaining or developing a certain posture 
regarding busing, magnet programs, the assignment and reassignment of students, the hiring and transfer of staff (Washington vs. Broward County, 1995b).

The judge ruled in favor of the plaintiffs, which prohibited the School Board from making any further race based decisions. This rendered starbursting and the denial of students into magnet programs based solely on race illegal. This was a perceived victory for CCC even though it was not CCC's case.

June 1996 - 1987 Consent Decree Vacated

Judge Ryskamp vacated the 1987 Consent Decree retroactive to August 1995 (Smith vs. McFatter, 1996a). He carefully worded the Order to give the School Board immunity from damages, meaning the School Board acted in good faith and in compliance with his Order. This would prevent CCC or any other plaintiff from claiming damages from the School Board's discriminatory desegregation policies and practices. May 1997 - Federal Judge Ryskamp Dismissed CCC

Judge Ryskamp ruled that CCC did not have standing to file a lawsuit against the Broward County School System. He implied that the School Board might have discriminated against black students; however, he did not feel that the discrimination was intentional. He allowed limited standing for the other two plaintiffs (Citizens Concerned About Our Children vs. Broward County, 1997a).

CCC members alleged that the judge was biased in favor of the School Board and the School Board's attorney. They claimed his sympathy toward the School Board was induced by his long time association with the School Board attorney with whom he 
attended law school. They were members of the same fraternity and both were School

Board attorneys, Ryskamp previously worked for the Dade County Public Schools. They also claimed that Ryskamp had shown unfairness and biases against $\mathrm{CCC}$ all along. He had a history of exhibiting biased behavior in the courtroom, making biased and premature decisions without allowing evidence to be presented, such as the case with CCC. CCC asked the judge to recuse himself and he refused. Their attorneys appealed this ruling and filed another motion on behalf of the other two plaintiffs.

September 1997 - CCC and Order on Standing

Judge Ryskamp issued an Order dictating the plaintiffs could only plead for themselves and not for other children in the School System. In essence, what he did was to deny them the same privilege he had previously granted to Ray Smith in the 1987 Consent Decree. The plaintiffs in this case were restricted to proving in a limited way that the School Board had discriminated against them without the ability to produce evidence. When the plaintiffs previously asked if they could make this a class action lawsuit, the judge said no. He subsequently dismissed their individual claims (Doe \& Shaq vs. Broward County, 1997).

January 1998 - Judge Ryskamp Dismissed all Lawsuits against School Board

\section{A Miami Herald editorial read:}

With glaring inequities in some of Broward schools, and a recent history of policies that worked against many black children, the conclusions of a federal judge seem hard to grasp. How could Judge Ryskamp throw out without a trial, a suit charging inequities in Broward's public schools when a number of heavily minority schools, but surely not all clearly lack the same equipment and advanced courses available elsewhere? Unless overturned on appeal, his decision clearly 
says that issues of inequities must be solved in the political arena, not in the courts ("Searching for Equity," 1998).

The plaintiffs in the CCC case responded to the dismissal of their three lawsuits by Judge Ryskamp's by filing appeals in the Appellate Court (11 ${ }^{\text {th }}$ Circuit) (Citizens Concerned About Our Children vs. Broward County, 1998a, 1998b). Table 4 gives a chronology of desegregation events in Broward County from 1970 to 1998.

Review of Historical Case Study Dissertations on School Desegregation Five different historical case study dissertations on school desegregation were researched. All of these case studies were completed between 1981 and 1986.

"Influence of the NAACP on federal educational policy from 1955-1965," explored the role of the NAACP and the extent to which it shaped federal educational policies. This study utilized a systems approach to record and analyze the data. More specifically, it employed Meranto's "model of legislative change" as the basis for its research design. The findings indicated that a major objective of the NAACP during that 10-year time period was the enforcement of the Brown decision. The NAACP achieved this objective through direct action of local NAACP branches, demanding denial of federal funds to school districts that refused to desegregate, leveraging black block voting, and helping to create strong civil-rights legislation (Patterson, 1984). Jack Washington (1983) conducted a study on, "School desegregation: A study of the decision-making process in the Trenton Public Schools 1955-79." His study attempted to answer the following questions: What part did the school administration play in school desegregation? What community input and resistance (if any) were part of the 
Table 4

Chronology of Desegregation Events

\begin{tabular}{|c|c|c|}
\hline Date & Year & Activity/Event \\
\hline January & 1970 & $\begin{array}{l}\text { Attorney George Allen filed desegregation lawsuit against Broward } \\
\text { County School Board. }\end{array}$ \\
\hline April 30 & 1970 & Final judgment entered by Court ordering school desegregation. \\
\hline June 21 & 1971 & $\begin{array}{l}\text { Judge Cabot entered an Order declaring School Board's Desegregation } \\
\text { Plan as adopted by prior Orders of the Court "constituted a unitary } \\
\text { school system." }\end{array}$ \\
\hline July 31 & 1979 & Judge Eaton relinquished jurisdiction of desegregation case. \\
\hline February 3 & 1983 & $\begin{array}{l}\text { Attorney Allen filed a second desegregation lawsuit against Broward } \\
\text { County School Board, Smith v. McFatter. }\end{array}$ \\
\hline April 29 & 1987 & $\begin{array}{l}\text { Desegregation Agreement, Smith vs. McFatter signed by Judge } \\
\text { Ryskamp, commonly called Consent Decree. }\end{array}$ \\
\hline \multirow[t]{3}{*}{ August 25} & 1989 & $\begin{array}{l}\text { School Board Attorney Marko sent memo to School Board members } \\
\text { informing them that earlier that week Judge Edward Davis stated the } \\
\text { Broward County School System was unitary based on evidence. }\end{array}$ \\
\hline & 1992 & $\begin{array}{l}\text { Lawsuit filed against the School Board by a group of white parents, } \\
\text { called Washington vs. School Board. }\end{array}$ \\
\hline & 1993 & $\begin{array}{l}\text { Supt. Sam Morgan created Desegregation Task Force. Members were } \\
\text { appointed under Supt. Petruzielo. }\end{array}$ \\
\hline January & 1995 & Desegregation Task Force made final report to the School Board. \\
\hline March & 1995 & Boundary hearings began. End of starbursting demanded. \\
\hline May & 1995 & $\begin{array}{l}\text { George Allen withdraws from desegregation case Smith vs. McFatter. } \\
\text { Three young black attorneys take over case. }\end{array}$ \\
\hline June 5 & 1995 & CCC files equity, discrimination lawsuit against School Board. \\
\hline August 16 & 1995 & $\begin{array}{l}\text { Judge Ryskamp granted summary judgment in Washington Case } \\
\text { declaring Broward County School System unitary. }\end{array}$ \\
\hline Sept. 19 & 1995 & Penny sales tax defeated by a 3 to 1 margin. \\
\hline February 1 & 1996 & $\begin{array}{l}\text { CCC presented school Superintendent with a settlement proposal. } \\
\text { School Board later rejected proposal. }\end{array}$ \\
\hline March 25 & 1996 & $\begin{array}{l}\text { CCC attorney sent letter to School Board offering to forego attorney } \\
\text { fees. }\end{array}$ \\
\hline June 13 & 1996 & Judge Ryskamp vacates Consent Decree retroactive to Aug. 16, 1995. \\
\hline May 13 & 1997 & $\begin{array}{l}\text { Judge Ryskamp dismisses CCC as plaintiff, saying CCC does not have } \\
\text { standing. }\end{array}$ \\
\hline September 5 & 1997 & $\begin{array}{l}\text { Judge Ryskamp rules on standing of } 2 \text { youth in CCC litigation. Cannot } \\
\text { plead for other children in School System. }\end{array}$ \\
\hline January 13 & 1998 & $\begin{array}{l}\text { Judge Ryskamp rules that } 2 \text { black plaintiffs were discriminated against } \\
\text { by School System and inequities do exist in School System, but not } \\
\text { intentionally. }\end{array}$ \\
\hline January 13 & 1998 & Judge Ryskamp dismisses all CCC's lawsuits. \\
\hline
\end{tabular}


desegregation issue in Trenton? What role and what part if any did governmental bodies outside of the school system play in school desegregation? And what were the dynamics of the decision-making process?

He concluded that school administrators played very important roles. They had the ability to impact district policies through their influence on school board members, the Commissioner of Education or the courts. He concluded that they could hinder or obstruct the implementation of policies and guidelines and to create confusion. Their actions basically depended upon their personal philosophies.

He found that community input could make or destroy a desegregation plan. The only nongovernmental agency he alluded to was the court system. He concluded that the courts had a wide array and very influential role in school desegregation because they had the power and authority to issue injunctions, restraining, and compliance orders.

He found that it was necessary to have a strategic plan based on educational goals not just the physical mixing of students as part of the decision-making process. He also suggested that the agendas from the major stakeholder groups be addressed. Those groups consist of the school board, community and school community. Washington employed the Agger, Goldrich, and Swanson model to organize the data and analyze the findings.

The next dissertation study is "Resegregation: A case study of an urban school district" (Masem, 1986). This was a historical case study of the Little Rock School District. Paul Masem utilized a systems analysis by Easton, Wirt, and Kirst. He 
examined the way the school system responded to desegregation. He found that none of the influencing forces were ever in total control and that for 20 years, the school district engaged in practices that opposed and delayed school desegregation. The black community litigated against the school district, finally resulting in the desegregation of the Little Rock School District; however, during the last 10 years the school district had become resegregated. The black community and white community agreed to a compromise remedy.

Masem concluded that the Little Rock School District's effort to oppose and delay the desegregation of the schools between 1957 and 1978 was primarily responsible for the resegregation of the district.

Patricia Rumer (1981) conducted a historical dissertation study on, "Citizen advocacy groups: An intervention strategy: A case study of the community coalition for school integration in Portland, Oregon." The purpose of this study was to identify what conditions were necessary for the successful intervention of a citizen advocacy group. It also identified the impediments to and attributes of successful interventions.

This study used the theoretical framework of Iannaccone's dissatisfaction model of governance. Rumer concluded that communication intervention is an intervening variable between the dissatisfaction stage and the defeat of incumbent elected officials. Six conditions were identified as being necessary for successful community intervention (timeliness' of the issue, financial resources, leadership, organizational support, staff, and media coverage). The major impediment to successful intervention was the lack of trust 
between the policy-making body (school board), the citizen advocacy groups, and the political environment of the community. Attributes that make interventions successful are advocacy that is focused, multiple intervention strategies, and the stability of the organization.

The next study was, "Trends in school desegregation: An historical case study of desegregation in Dayton, Ohio; Denver, Colorado; Los Angeles, California; and Seattle, Washington 1954-1985" (Adair, 1986).

The purpose of the study was to develop an analysis of issues and trends of the four aforementioned school districts regarding school desegregation. Adair did not utilize any theoretical model to synthesize and analyze her data. She conducted her own analysis of data collected from questionnaires, telephone and personal interviews. She analyzed the data for common historical developments, characteristics, conditions, practices, patterns, and problems.

Her findings were that the Brown Supreme Court Decision did not meet its intended objective of desegregating and integrating schools or providing educational equity. As a result of this failure, the black community became less concerned about desegregation and more concerned about quality education, be it in a predominately white or predominately black school.

\section{Review of the Literature on Power}

An exploration of the topic of power-how, why and by whom it is wielded--begs an understanding of the sociological and philosophical origins and underpinnings of 
power. According to Russell, the concept of power has always existed amongst humans and the love of power is human nature. "Of the infinite desires of man, the chief are the desires for power and glory" (Russell, 1938, p. 11).

A review of the literature suggests that there are three primary schools of thought regarding power. There is the pluralist view, the structural-functionalism view and the power-structure view. The events and activities in Broward County, Florida seem to fit into the Power-Structure view.

The Power-Structure View

Power-structure theorists believe that political power is defined through a map of networks of influence on government, based on institutional and informal social ties (Miller, 1984). Some of the social scientists who subscribe to this theory are Floyd Hunter, C. Wright Mills, G.W. Domhoff, Thomas Dye and Andrew Hacker. The powerstructure theorists can be identified by the use of such terms as the power elite, the ruling class, institutional elitism and class domination.

C. Wright Mills who is considered a radical sociologist created the concept of institutional elitism in the $1950 \mathrm{~s}$. He asserted that America was ruled by a "power elite" that was based in the three most important hierarchies in the country; the executive branch of the federal government, the military and in corporations. He criticized the pluralist's view of power for not understanding or acknowledging the presence of a small power elite at the top and a large group of powerless people at the bottom. He also 
criticized the Marxists for being shortsighted about the autonomy of what he called the "political order" (Mills, 1956).

Two conservative political scientists, Andrew Hacker and Thomas Dye later promoted Mill's theory of institutional elitism. Dye wrote that great power is institutionalized and is derived from roles in social organizations (Dye, 1972). Those that occupy top positions in institutions possess power whether they use it or not.

Domhoff in his book, Who Rules America Now? puts forth a very strong and convincing argument in support of the power-structure theory. He said that:

Contrary to the pluralistic view of power, there is a social upper class in the U.S.A. that is a ruling class by virtue of its dominant role in the economy and government and that this ruling class is socially cohesive, has its basis in the large corporations and banks, plays a major role in shaping the social and political climate, and dominates the federal government through a variety of organizations and methods (Domhoff, 1983, p. 1).

He goes on to say that: The upper class as a whole does not do this ruling. Instead,

Class rule is manifested through the activities of a wide variety of organizations and institutions. These organizations and institutions are financed and directed by those members of the upper class who have the interest and ability to involve themselves in protecting and enhancing the privileged social position of their class. Leaders within the upper class join with high-level employees in the organizations they control to make up what he calls the power elite (Domhoff, 1983, p. 2).

The term "ruling class" is generally associated with Karl Marx and his philosophy which has standardized the concept of the "ruling class" to be the bourgeoisie. Miller says that the shortcoming of this is that there has never been a clear, precise definition of the term ruling class. He attempts to construct a definition of ruling class without 
compromising Marx's theories on social politics and history. He paraphrases some of

Marx's assumptions as outlined in the Communist Manifesto:

A social group or coalition of social groups is a ruling class politically if government does what its long-term interests dictate, if there are definite mechanisms at any given time maintaining this connection between actions and interests, and if this connection cannot be broken by activities that government permits. Thus with certain hedges and distinctions, the state acts as if it was an executive committee for managing the common affairs of the bourgeoisie, is exclusively guided by their long-term interests and will continue to be so guided unless defeated by physical challenges that it does not permit (Miller, 1984, p. 113).

Miller further elaborates, "

To the extent there is a ruling class, ordinary citizens must go outside of normal channels, engaging in risky, unacceptable activities in order to get their issues addressed. In doing so the government may foil and complicate these efforts to protect the interests of big business"(Miller, 1984, p. 113).

Domhoff proposes three different types of indicators to measure power: (a) Who

benefits? (b) Who governs? and (c) Who wins?

After examining the literature on community power-structures and city

development, sociologist Harvey Molotch concluded that:

A community power structure is at bottom an aggregate of land-based interests that profit from increasingly intensive use of land. It is a set of property owners who see their futures as linked because of a common desire to increase the value of their individual parcels (Cited in Domhoff, 1983, pp. 166-167).

The most typical way of intensifying land use is growth, and this growth usually expresses itself in a constantly rising population. A successful local elite is one that is able to attract the corporate plants and offices, the defense contracts, the federal and state agencies, or the educational and research establishments that lead to an expanded work force, and then in turn to an expansion of retail and other commercial activity, extensive land and housing development, and increased financial activity (Cited in Domhoff, 1983, pp. 166-167). 
Molotoch expounds by saying the biggest and most important duty and concern of the community power-structure is to provide the proper conditions for outside investment. They must get involved in creating a "good business climate," i.e., an infrastructure of local services, aggressive law enforcement, and a passive labor force (Cited in Domhoff, 1983). All of those interests that depend on and profit from the land ownership are included in this power-structure, i.e., banks, telephone company, and utilities companies. Newspapers are also included in the power structure.

\section{The Ethics of Power}

Russell says there must be a differentiation between power desired as a means and power desired as an end in itself and that the exercise of power must be judged based on its effects (Russell, 1938). He explains that the love of power "is the desire to be able to produce intended effects upon the outer world, whether human or non-human" (Russell, 1938, p. 262) and that "the beneficent love of power must be bound up with some end other than power" (Russell, 1938, p. 264). In order for power to be beneficent, Russell ascribes three characteristics: (a) the purpose for the power must be one that help to satisfy the desires of others, (b) the purpose must be compatible with the desires of the people who will be impacted, (c) the means for accomplishing the purpose must not have bad consequences or outweigh the general purpose of the exercise of power (Russell, 1938).

Russell summarizes his position by saying "the ultimate aim of those who have power should be to promote social co-operation, not in one group as against another, but 
in the whole human race" (Russell, 1938, p. 264). He said if he had to select four men who have more power than anyone else, he would choose Buddha, Jesus, Pythagoras and Galileo. None of them were popular with their governments or recognized for their goodness and accomplishments until after their deaths. Their power was exercised not for themselves but for others, for the salvation, liberation, and enlightenment of the people (Russell, 1938).

Wartenberg theorizes that power is a necessary evil. "It seems a necessary and positive feature of both an individual's life and society; on the other, it seems to be the root of many of the deepest problems of a society" (Wartenberg, 1990, p.10). In line with Russell's view Wartenberg says, "it (power) can be either a negative social presence or an importantly beneficial one depending on the nature of its use" (Wartenberg, 1990, p. 11). The question of whether or not power is positive or negative must be answered in regard to the specific form that a power relation has in a particular situation (Wartenberg, 1990). Forms of Power

Russell. Bertrand Russell is an iconic figure who is known as a philosopher, logician, social critic and Nobel Laureate in Literature. He states that "there are various forms of power, each with its own utility" (Russell, 1938, p. 35). There is a difference in the acquisition of power between individuals and the acquisition of power between organizations, though the two are interrelated (Russell, 1938). He acknowledged there is power over human beings and power over non-human forms (Russell, 1938). 
Russell uses the term "influence" interchangeably with the term "power." What he says about influence is this, "A person can be influenced by direct physical power over his body, by rewards and punishments as inducements and by influence on opinions" (Russell, 1938, p. 36). The forms of power that an individual will choose to use will depend upon his temperament, opportunities and skill (Russell, 1938).

Organizations, he asserts can be distinguished by the kind of power they exert. Economic organizations will ordinarily use rewards and punishments as incentives and deterrents; schools, churches, and political parties will most likely use influencing opinions (propaganda being only one type); the military and police will exercise coercive power (Russell, 1938). He creates seven different categories for the different forms of power: priestly power, kingly power, naked power, revolutionary power, economic power, power over opinion, and creeds as sources of power (Russell, 1938).

Priestly power and kingly power are virtually extinct now and existed mainly in the primitive and old cultures of the world characterized by medicine men, priests and kings during the classical ages. The remnants of which can currently be found in the Papacy of the Catholic Church and the monarchy in parts of Europe, Asia, Africa and the Middle East. He refers to this as traditional power and it is usually inherited. There is little concern about resistance because the reign of power is based on the traditional culture of the respective societies.

Naked power refers to military power. Power not based upon tradition or assent. Naked power usually comes into existence when there is a decline of traditional power 
and is usually obtained for and by individuals through fear, intimidation and for personal and selfish reasons.

Revolutionary power is distinguished from naked power by the coming together of groups within a society under the creed of a particular doctrine or purpose.

Economic power is alluded to be based on the acquisition of land and is backed up by military or physical force or power. Russell says that the relationship between economic power and military power has never before in history been so closely aligned as it is today. He suggests a reciprocal relationship between economic power and military power, whereas one can obtain economic power if they have military power and one obtain military or police power if one has economic power.

Power over opinions is described by Russell as being, perhaps, the most important and potent form of power. He says all other power emanate from here. The exercise of all the other forms of power will be weakened without the power to influence, persuade, coerce and manipulate. This is discharged through the recitation of thoughts, ideas, information and the promotion of propaganda.

Creeds as sources of power are considered essential to social cohesion and harmony. When they are absent, it may be necessary to utilize or exercise other, more oppressive, forms of power. Creeds are social codes or beliefs that are based on factual information or a commonly accepted philosophy.

It is necessary to acknowledge another form of power that Russell alludes to which is a form of discreet individual power. He calls it: 
Power behind the scenes: the power of courtiers, intriguers, spies, and wirepullers. In every organization, where the men in control have considerable power, there are other less prominent men and women who acquire influence over the leaders by personal methods. Wirepullers and party bosses belong to the same type, though their technique is different. They put their friends, quietly, into key positions, and so, in time, control the organization (Russell, 1938, p. 48). The qualities required for power behind the scenes are very different from those required for all other kinds, and as a rule, though not always, they are undesirable qualities. A system, which accords much power to the courtier or the wirepuller, is therefore, in general not a system likely to promote the general welfare (Russell, 1938, p. 49).

Wartenberg. Thomas Wartenberg is a Professor of Philosophy at Mount Holyoke College. He discusses the topic of power in the context of hierarchical social relations and provides a view about how power is manifested socially and politically.

Wartenberg's theory of "power-over" is an attempt to explain the complex notion of the concept of power in human relationships. He said "power is exercised over an agent when he is not able to act freely, that is with the full set of possibilities available to him" (Wartenberg, 1990). He defined an individual's power over another in the following manner: "Social agent $A$ has power over social agent $B$ if and only if $A$ strategically constrains $B$ 's action-environment" (Wartenberg, 1990, p. 85). He delineates three different forms of power: force, coercion, and influence (Wartenberg, 1990).

Force of power is successful as a form of power when it achieves its goal of hindering another person from achieving his/her wishes or objectives or being responsible for a person meeting some undesired end. Force can be exercised in a physical and non-physical manner. 
Coercive force can only be exercised, according to Wartenberg, by an agent. A person exercises coercive power over another person when the following conditions are present: (a) $A$ has the ability to affect $B$ in a significant way. (b) $A$ threatens to do so unless $B$ acts in a certain way. (c) $B$ accedes to $A$ 's threat and alters his course of action.

Let it be noted here, according to Wartenberg, that rather than the three forms of power being distinct, they form what he calls a tripartite strategy (Wartenberg, 1990) meaning they have an interdependent relationship. Thus, force can stop $A$ from doing something, but it cannot get $A$ to do something. $A$ must be coerced.

Influence and its forms. Wartenberg extends the other forms of power (force and coercion) into a more stable social situation (Wartenberg, 1990). Influence fulfills the interest of the dominant agent in having his/her power over a subordinate agent misrepresented (Wartenberg, 1990). Wartenberg separates influence into three different types: rational persuasion is when another person can provide information to an individual resulting in that person changing his/her perspective or evaluation of a situation. Another type of influence is personal persuasion, which is seen in charismatic leadership. The dominant agent does not appeal to the person's sense of reason by presenting new and persuasive information, but uses his/her charisma or status -in other words, the just "trust me." routine. The person affected, therefore, is not able to give a reasonable and sound explanation for his/her decision; he/she must defer to the other person. The third type of influence is called expertise, whereby an individual accepts the advice and bases his/her action upon the advice of a person assumed to be an expert. 
There is distributive expertise that gives a person direct and specific information to solve a technical situation, such as that of a doctor. There is apprenticeship expertise that provides a person with some generalized knowledge about how to proceed with a situation (Wartenberg, 1990).

Manipulation is described as a type of influence that is divided into emotional and cognitive manipulation. Cognitive manipulation is when a person attempts to influence another person's actions by withholding, modifying or distorting information, purpose and intent.

Emotional manipulation deliberately appeals to a person's feelings in order to exact a particular response and action. Russell explains that manipulation is related to power "because the subordinate agent's action-environment is being constrained by the action of the dominant agent" (Wartenberg, 1990, p. 111). Manipulation is considered by most power theorists to be a morally suspect social practice that is dubious in nature (Wartenberg, 1990).

Galbraith. John Kenneth Galbraith is a Professor Emeritus of Economic at Harvard University. In his book Anatomy of Power (1983), Galbraith theorizes that there are three basic ways in which power is exercised or enforced. He classifies them as condign, compensatory and conditioned power. He then proposes three different sources of power: personality, property, and organization. It is important to mention this point, as stated by Galbraith:

There is a primary but not exclusive association between each of the three instruments by which power is exercised and one of the sources, so there are also 
numerous combinations of the sources of power and the related instruments. Personality, property and organization are combined in various strengths. From this comes a varying combination of instruments for the enforcement of power (Galbraith, 1983, p. 7).

Condign power forces the submission of a person to abandon his/her pursuits by making a physical or emotional threat (Galbraith, 1983).

Compensatory power forces submission by offering or promising a reward or payment for the abandonment of a pursuit. Galbraith maintains that there is more tolerance in most societies for compensatory power than for condign power. Compensatory power is accepted as more civil and civilized than condign power. In both types of power the individual influenced is aware of his/her submission (Galbraith, 1983). Conditioned power has more of a psychological function to it. The person is persuaded or influenced to do something without being aware of it. Matter-of-fact Galbraith stated that "neither those exercising it (conditioned power) nor those subject to it need always be aware that it is being exerted" (Galbraith, 1983, p. 24).

The acceptance of authority, the submission to the will of others, becomes the higher preference of those submitting persuasion or education can deliberately cultivate this preference. Or it can be dictated by the culture itself; the submission is considered to be normal, proper, or traditionally correct. This is implicit conditioning (Galbraith, 1983, p. 24).

The source of power as conveyed by Galbraith differentiates those who exercise power from those who submit to power. As stated previously the sources of power are all interrelated and interdependent upon each other. Personality is enhanced by property and property is enhanced by personality. They also have an accompanying instrument of power. Personality is usually associated with condign power. Property with compensatory power and organization with conditioned power (Galbraith, 1983, pp. 38-39). (See Figure 2). 
Personality refers to the quality and influence of a person's physique, mind, speech, moral certainty, aura and other traits that may not be listed here. This particular source has the power of persuasion over other people's minds, ideas and beliefs, resulting in an effect on their actions.

Property has always been thought to give access to social and political influence and to contain intrinsic power over the conditioned beliefs of people. People once were very much interested, concerned and influenced by the beliefs of rich people; however, this is not necessarily the case today.

Wealth, per se, no longer gives automatic access to conditioned power. The rich man who now seeks such influence hires a public relations firm to win others to his beliefs. He may contribute to a politician or a political action committee that reflects his views, or he may go into politics himself and use his property to persuade voters rather than to purchase votes. Social conditioning, so purchased, is the most visible current manifestation of the power deriving from property (Galbraith, 1983).

Organizations are the most important of the sources of power. Organizations can have access to condign power; in their normal association with property, they have access to compensatory power. Especially in their modern forms, organizations have access to conditioned power (Galbraith, 1983).

Galbraith argues strongly that organizations have the power to influence the submission of people, from both inside and outside the organization, to its purpose. He said "an organization is strong when it has effective access to all three of the instruments 
of power" (Galbraith, 1983, p. 57). He speaks about the bimodal symmetry of organizations, meaning that people usually submit to the common purpose of organizations they work for as a conditioned response (Galbraith, 1983).

Organizations develop mechanisms to ensure the conditioning of its members because nothing is more effective in threatening the external power of organizations as the "undisciplined expression of dissenting views from within" (Galbraith, 1983, p. 60). There are some major similarities between Wartenberg's "forms of power" and Galbraith's "instruments of power" (see Figure 2). Table 5 illustrates the various forms of power previously discussed.

Thus far, an understanding of power from a historical, sociological and philosophical point of view has been presented and an attempt has been made to explain the meaning, reason, purpose and exercise of power in social relations. In order to make the discussion of power more relevant to today's events, the thinking of two other authors will be explored and exploited. The previous authors and scholars on the topic of power-with the exception of Galbraith—have been political and social scientists, sociologists, and philosophers.

In addition to the foregoing discussions of power, the concept of power in the context of corporate, bureaucratic and community organizations requires explanation. One of the authors/scholars who will be referenced is Jeffrey Pfeffer, Professor of Organizational Behavior at Stanford University. The other is Oba T'Shaka, Chairman of the Black Studies Department at San Francisco State University. He has been a self- 


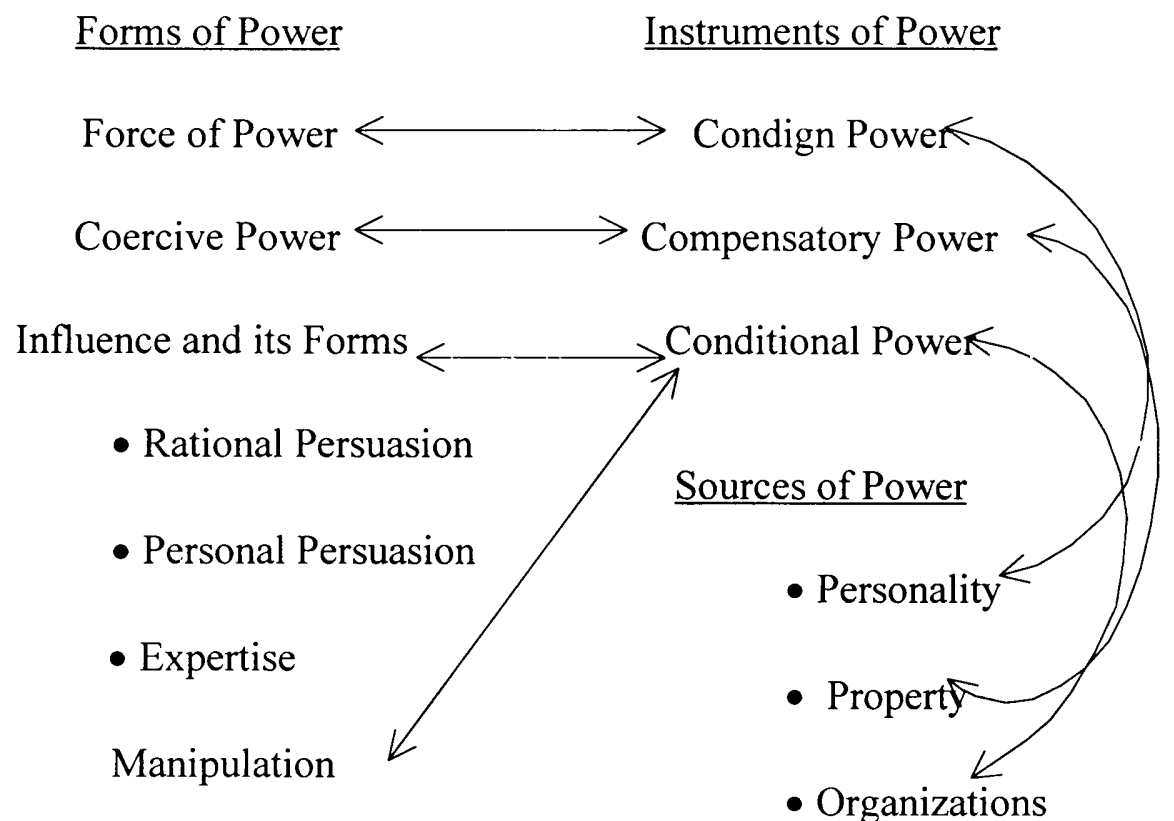

Figure 2. Comparison of Wartenberg and Galbraith theories on power.

Table 5

Forms of Power

\begin{tabular}{cll}
\hline \multicolumn{1}{c}{ Galbraith } & \multicolumn{1}{c}{ Russell } & \multicolumn{1}{c}{ Wartenberg } \\
\hline Instruments of Power & Priestly/Kingly Power & Force of Power \\
Condign Power & Naked Power & Coercive Force \\
Compensatory Power & Revolutionary Power & Influence \& its Forms \\
Conditional Power & Economic Power & Rational Persuasion \\
Sources of Power & Power over Opinions & Personal Persuasion \\
Property & Creeds as Sources of Power & Expertise \\
Personality & & Manipulation \\
Organizations & & \\
\hline
\end{tabular}


proclaimed community activist for more than 40 years. Since the Broward County

School Board's exercise of power will be examined in the context of how it interfaced with the community (mainly the black community) regarding desegregation, it is important to give a perspective about power structures in black communities.

T'Shaka. In his book, The Art of Leadership (1990), he admonishes community activists to first learn as much as possible about their local communities or whatever community in which they are active. He offers that national black organizations such as the Urban League and the National Association for the Advancement of Colored People (NAACP) have significant influence on political issues in local black communities. Community activists need to understand the nature and scope of their influence. He also says there is a black establishment in every black community that consists of influential black and white people that control the black community. These people and their organizational affiliation need to be identified.

T'Shaka (1990) borrows from Lerone Bennett's book Black Mood, in describing a "shadow cabinet" which consists of representatives from white liberal organizations. The shadow cabinet allegedly supplies the black establishment with white people to serve on their boards in leading roles, train black people to assume leading roles within the black establishment and to serve on boards in the white community. This cabinet also sets limits for what is appropriate and inappropriate for the black establishment. T'Shaka equates the role and function of the shadow cabinet to that of neocolonizers in Africa, whereby, they train elitist blacks to carry out the wishes and mandates of the white power 
structure and in essence control all other black people in their respective communities.

He asserts that the black elite acts as a buffer between the black masses and the oppressive white power structure. They often have contempt for their own black people (T'Shaka, 1990).

T'Shaka proposes that the best way to get around the black establishment is to form grassroots activities. He acknowledged in this book the growing schism between poor blacks and middle-class blacks, saying middle-class blacks and traditional black institutions have deserted poor blacks (T'Shaka, 1990).

Black community leaders and elected officials may or may not be part of the shadow cabinet, therefore it is important to also assess what their relationships are with the white power structure (T'Shaka, 1990). He cautions that the black press and the black church may be part of the black establishment and have a connection with the white power structure. It may be necessary, therefore, not to expect support from them, but they should also be included in the assessment.

T'Shaka (1990) advises to be careful of opposition leadership. Expect other blacks to try to impede your efforts. They may be acting on their own behalf or they may have been charged by the white power structure. In any case, the rationale may be to neutralize your efforts or to remove competing leadership to impress the white power structure in search of some kind of reward. Their strategy may be any of the following: create negative propaganda to discredit individuals or the organization, infiltrate and create division, generate diversions, or capture the leadership of the organization. 
Pfeffer. He advises that one's success in organizations depends upon one's ability to analyze the relative power of the various participants and understand the patterns of interdependence. He contends that there is a relationship between power and knowledge. Those who have more accurate information tend to have more power (Pfeffer, 1992). Power, he explains is used to take action and the determination of who benefits and to what extent reveals who has power (Pfeffer). In discussing the dynamics of power in organizations, he remarked that change and adaptation come only through political struggle. Those wielding power are usually so blinded by their vested interests that they oppose any change. Therefore, change almost always comes from people outside the mainstream in the organization or outside the organization (Pfeffer, 1992).

\section{Summary}

School districts throughout the United States. were slow to respond to the 1954 and 1955 Supreme Court's order to desegregate schools and Broward County was no exception. Broward County desegregated its School System under duress in 1971, following a lawsuit filed by Attorney George Allen. The argument used by attorneys for the plaintiffs in Brown vs. Board of Education was based on a social science theory that segregation caused low-esteem in black children which was responsible for lack of confidence and low aspirations in black children. These conditions led to lack of achievement. No conclusive studies have been conducted to prove one way or the other that desegregation has improved or not improved the performance of black children. 
Parents in Broward County became disenchanted with desegregation, consistently criticized the School Board's desegregation plan and finally filed lawsuits against the School Board because of the unfairness of its desegregation plan to black children.

Five different historical case study dissertations on desegregation were reviewed. All of them were completed between 1981 and 1986 and dealt with the issue of power in some aspect. Four theoretical models of power were reviewed for their practicality in analyzing the power relationship between the Broward County School System and the grassroots community. 


\section{CHAPTER III}

\section{METHODS}

Chapter III describes the research method used in this study. This is a historical case study on the use of power in efforts to desegregate the Broward County School System between 1970 and 1998. This Chapter is organized in the following manner: the study's method is presented in terms of data collection procedures, the analysis of data, a description of the participants and the basis for their selection, a description of the archival data source, and a description of the researcher's role, which includes 12 different scenarios that were responsible for stimulating the researcher's interest in the research topic.

\section{Case Study Method}

The historical case study method of research was selected for this study because of its suitability to the purpose of the study. Historical researchers may use a wide range of data sources and numerous methodologies (Berg, 1998). Historical documentation includes both written and oral sources. It is an attempt

...to uncover the unknown; to answer questions; to seek implications or relationships of events from the past and their connections with the present; to assess past activities and accomplishments of individuals, agencies, or institutions; and to aid generally in our understanding of human culture, (Berg, 1998, p. 200).

Stake maintains that case study is not a method, but rather a choice of subjects to be studied. It may be simple or complex. The researcher may be more interested in a phenomenon than in an individual case. Stake identifies three types of case studies: 
intrinsic, instrumental, and collective. An intrinsic case study involves one case that is of particular interest to the researcher. An instrumental case study involves a particular case in order to provide insight into an issue or to refine a theory. The collective case study involves several cases to provide a better understanding of certain phenomena, populations or conditions (Stake, 1994).

Based on Stake's description of case studies, this study is most closely related to the intrinsic type. Stake notes that those with intrinsic interests conduct most case studies.

Case studies require that researchers learn enough about the case to encapsulate complex meaning into a finite report and to describe the case in sufficient descriptive narrative so that readers can vicariously experience these happenings, and draw their own conclusions" (Stake, 1994, p. 243).

This researcher has specific involvement and interest in school desegregation and has been a close observer of the School System as a power-brokering agency. The case of Broward County was selected because of its potential to advance understanding of that broader interest. The researcher also wants to provide greater insight into the specific issue of desegregation in Broward County and the power relationships between the School Board and community, as well as how and why certain desegregation decisions were made.

Leedy defines case study research as "a type of descriptive research in which data are gathered directly from individuals, social or community groups in their natural environment for the purpose of studying interactions, attitudes, or characteristics of individuals or groups" (Leedy, 1985, p. 93). 
According to Merriam, a case study is a thorough exploration and examination of a single subject, setting, event or documents (Merriam, 1988). The case study method is an approach to gathering data that uses a variety of data-gathering techniques such as interviews, archival data, and observations (Hamel, Dufour \& Fortin, 1993). On the other hand, historical research typically relies on data that is already available.

As noted previously, the purpose of his study is to describe, explain and analyze the historical elements of power inside and outside the Broward County School System as it relates to school desegregation. The historical case study method seems to be the best approach to answering the theoretical questions of who benefited from the School Board's policies on desegregation, who governed desegregation policies, and who won when there was a dispute over desegregation policies?

The case study method is a common research approach used in the study of school desegregation. Some of the school desegregation cases (dissertations) the researcher reviewed, using this approach are the following: Resegregation: A case study of an urban school district (Masem, 1986); School desegregation: A study of the decision-making process in the Trenton public schools 1955-79 (Washington, 1983); The influence of the NAACP on federal educational policy from 1955-1965 (Patterson, 1984); Citizen advocacy groups - an intervention strategy: A case study of the community coalition for school integration in Portland, Oregon (Rumer, 1981); and Trends in school desegregation: An historical case study of desegregation in Dayton, Ohio, Denver, Colorado, Los Angeles, California, and Seattle, Washington (Adair, 1986). 
The first four studies used theoretical frameworks or models to conceptualize the research questions and to analyze the data. The fifth study however, did not utilize a theoretical model, but rather synthesized the information from all data sources (interviews and questionnaires), then analyzed the information for common historical developments, characteristics, conditions, practices, patterns and problems which were ongoing in school desegregation processes in four different school districts.

\section{Procedures}

\section{Collection and Analysis of Data}

The data were collected using in-depth interviews with 11 participants and data from 10 archival sources. The following nine research questions, presented earlier in chapter I, provide a framework for data analysis:

1. What are the factors that made school desegregation an important power issue in Broward County?

2. Who were the principal power players that governed the school board's desegregation policies and practices?

3. What were the power techniques used by the power players to influence desegregation policies and decisions?

4. How were decisions made regarding school desegregation? Who was consulted? Who was involved in desegregation decisions?

5a. Were there any individuals or groups that were successful in influencing desegregation in Broward County? If so, who were they? 
5b. In what way did they influence desegregation or what was the impact of their involvement?

6a. Who benefited the most and who won from the school board's desegregation policies and practices?

6b. What were the benefits?

7. What was the response from the overall African American community to the school board's desegregation policies, plans, and practices?

The data used to answer the above questions were also used to explore the theoretical questions posed by Domhoff in his indicators of power: Who benefited from the school board's policies and practices on desegregation? Who governed desegregation policies and practices, and who won when there was a dispute over desegregation policies and practices?

A frequency count was performed based on how each of the data sources (interview and archival sources) responded to the research questions and to Domhoff's three indicators of power. A single count of one (1) was given regardless of how often a participant may have addressed any of the research questions or Domhoff's indicators of power. Tables are provided for most of the responses to the research questions and to Domhoff's indicators of power.

\section{Participants}

At the beginning of the research study, the first six people below were selected to be interviewed as primary sources of information. They were selected because they 
could give a firsthand account of their own involvement with school desegregation in Broward County as well as provide secondary sources of information. They were authenticated based on their primary involvement with school desegregation by virtue of their job function or community involvement. Their substantial involvement with school desegregation has been confirmed by the electronic and printed media; through their attendance, participation and involvement at School Board meetings, boundary hearings and community meetings. The other participants also validated them as primary data sources.

The last five individuals were interviewed as primary sources of data after being identified during interviews with the initial six participants. All of the individuals interviewed passed the test for being considered primary data sources. They were present, active participants and/or observers in some form pertaining to school desegregation during the time frame studied (1970-1998).

The information provided by the participants in the interviews was assessed for accuracy, authenticity, and biased motives. The researcher, because of her involvement in desegregation issues as a participant and non-participant observer was able to assess for internal and external criticism. The responses from the participants were also compared to the responses from other participants interviewed as well as against the archival data in order to determine accuracy and authenticity. The 11 persons interviewed are listed below: 
1. George Allen was the attorney for the plaintiffs in the 1970 and 1987 desegregation lawsuits. He was the overseer of desegregation in Broward County for 25 years.

2. William Dandy is a retired, high-ranking black School Board official, who is considered the architect and guardian of desegregation in Broward County for more than three decades. Mr. Dandy is considered a major power broker in the black community who is well respected and well known in the white and black communities. He was also the liaison to the Bi-racial Committee and a member of the Boundary Committee as well as a former Area and Deputy Superintendent.

3. Chris Fertig is a private attorney who filed several desegregation lawsuits against the Broward County School System over the past decade regarding student assignment and boundaries and equity issues. He is the attorney of record for Citizens Concerned About Our Children (CCC) and the Washington, et al., cases. Prior to engaging in litigation against the School Board, Mr. Fertig and his wife (Mary) were parent activists who had solidified a relationship with black activists regarding desegregation and equity issues.

4. Dr. William Leary is a former Superintendent of Broward County schools (1984-1987). He was Superintendent when the School 
Board settled the 1987 desegregation lawsuit with Attorney George Allen.

5. Ernestine Price is a parent and education activist for more than 25 years. Her activism began when the first Broward County school desegregation plan called for the closing of Blanche Ely High School, the traditional black high school in the northern part of Broward County. She and others fought for five years to get Blanche Ely reopened. Since then, she has become the major spokesperson on education issues for black people living in the northern part of Broward County (Pompano and Deerfield Beach). She is also a founding member of CCC and participated on the Desegregation Task Force.

6. Lois Wexler is a School Board member who has had more dialogue and involvement with school desegregation than any of her current colleagues. She is also aware of the power players and power brokers inside and outside the School System, as well as in the white and black communities.

7. Mary Fertig is the wife of Attorney Chris Fertig and an education activist. She was chairperson of the Student Assignment SubCommittee of the Desegregation Task Force, and a friend and consultant to CCC. 
8. Eileen Lieberman is a Broward County Commissioner. She is the former Mayor of the City of Lauderhill and was an active participant in desegregation issues in the 1980s and 1990s.

9. Carlton Moore is a Commissioner for the City of Fort Lauderdale and is a former President of the Fort Lauderdale NAACP.

10. Lori Parrish is a Broward County Commissioner and was a School Board member when the 1987 Consent Decree was settled.

11. Neil Sterling is a former School Board member. He was Chairperson of the School Board when the 1987 Consent Decree was settled with George Allen and took the initiative to negotiate a settlement agreement.

Three other people were identified as primary data sources. They were contacted for interviews and either did not respond or were unavailable. They are Lee Stepanchek, who has served in various positions dealing with desegregation issues since the mid1980s; Samuel Morgan, the Superintendent after Leary (1988-1994); and Edward Marko, School Board attorney for more than 30 years. Marko referred the researcher to Attorney Allen.

\section{Participant Interviews}

Participants received a personal phone call from the researcher asking for their participation in the research study and explaining the purpose of the study. All the interviews were conducted between September 20, 2001 and September 25, 2002. The interviews took an average of two hours each to conduct. All the participants (except 
one) gave their permission to audiotape the interviews. They all signed informed consent forms, which stated the purpose of the study and the potential benefits and harm.

Each participant was asked a series of 15 interview questions (see interview questions in Appendix A) designed to elicit responses related to the study's research questions. All interviews were transcribed. The interview questions were crossreferenced with the nine research questions as exhibited in Table 6.

The research questions were further cross-referenced against Domhoff's three indicators of power (see Table 7). The archival data were subjected to the same method of cross-referencing between the research questions and Domhoff's three indicators of power. (See Table 8).

Archival Data

Archival data as secondary sources were reviewed and used to corroborate and authenticate the information reported by the participants. Berg says that secondary sources of information can be helpful in establishing the external and internal validity of other information collected. If there is consistent corroboration through various secondary sources, this can determine the accuracy of information provided by a primary source, which is referred to as internal criticism, and hence, document the reliability of the information provided (Berg, 1998).

The secondary sources of data used in this study include information from what Berg (1998) refers to as public archives. Archival data sources that dealt with desegregation from 1970 to 2000 were identified. These sources were reviewed and 
Table 6

Cross-Reference of Interview and Research Questions

Research questions

\begin{tabular}{|c|c|c|c|c|c|c|c|c|c|}
\hline \multirow{2}{*}{$\begin{array}{l}\text { Interview } \\
\text { questions }\end{array}$} & \\
\hline & $\# 1$ & $\# 2$ & $\# 3$ & $\# 4$ & $\# 5 \mathrm{a}$ & $\# 5 b$ & $\# 6 a$ & $\# 6 \mathrm{~b}$ & $\# 7$ \\
\hline 1 & & $x$ & & & $x$ & & & & $\mathrm{x}$ \\
\hline 2 & & $x$ & $\mathrm{x}$ & & $x$ & $\mathrm{x}$ & & & $\mathrm{x}$ \\
\hline 3 & & $x$ & & & $x$ & $x$ & & & \\
\hline 4 & & $\mathrm{x}$ & & $x$ & $x$ & & & & $\mathrm{x}$ \\
\hline 5 & & $\mathrm{x}$ & $\mathrm{x}$ & $x$ & $\mathrm{x}$ & $\mathrm{x}$ & $\mathrm{x}$ & & $\mathrm{x}$ \\
\hline 6 & $x$ & & & & & & $\mathrm{x}$ & $\mathrm{x}$ & \\
\hline 7 & $\mathrm{x}$ & & & & & & $\mathrm{x}$ & $\mathrm{x}$ & \\
\hline 8 & $\mathrm{x}$ & & & & & & $x$ & $x$ & \\
\hline 9 & $\mathrm{x}$ & & & & & & $x$ & $x$ & \\
\hline 10 & $x$ & & $\mathrm{x}$ & & & & $\mathrm{x}$ & $x$ & \\
\hline 11 & $\mathrm{x}$ & & $\mathrm{x}$ & $\mathrm{x}$ & & & $\mathrm{x}$ & $\mathrm{X}$ & \\
\hline 12 & & $\mathrm{x}$ & $\mathrm{x}$ & $x$ & $\mathrm{x}$ & $\mathrm{x}$ & $\mathrm{X}$ & $x$ & \\
\hline 13 & $x$ & $\mathrm{x}$ & $\mathrm{x}$ & $\mathrm{x}$ & $x$ & $\mathrm{X}$ & $\mathrm{x}$ & $\mathrm{x}$ & $\mathrm{x}$ \\
\hline 14 & & & & & $\mathrm{x}$ & $\mathrm{x}$ & $x$ & $x$ & $\mathrm{x}$ \\
\hline 15 & & & & & $x$ & $\mathrm{x}$ & $x$ & $\mathrm{X}$ & $\mathrm{x}$ \\
\hline
\end{tabular}

Note. The $\mathrm{x}$ indicates which research question is answered by the interview questions. 
Table 7

Cross-Reference of Research Questions with Domhoff's Power Indicators

\begin{tabular}{cccc}
\hline $\begin{array}{c}\text { Research } \\
\text { questions }\end{array}$ & $\begin{array}{c}\text { Who } \\
\text { benefited? }\end{array}$ & $\begin{array}{c}\text { Who } \\
\text { governed? }\end{array}$ & $\begin{array}{c}\text { Who } \\
\text { won? }\end{array}$ \\
\hline 1 & $\mathrm{x}$ & $\mathrm{x}$ & $\mathrm{x}$ \\
2 & & $\mathrm{x}$ & \\
3 & & $\mathrm{x}$ & \\
4 & $\mathrm{x}$ & $\mathrm{x}$ & $\mathrm{x}$ \\
$5 \mathrm{a}$ & $\mathrm{x}$ & $\mathrm{x}$ \\
$5 \mathrm{~b}$ & $\mathrm{x}$ & & $\mathrm{x}$ \\
$6 \mathrm{a}$ & $\mathrm{x}$ & & $\mathrm{x}$ \\
$6 \mathrm{~b}$ & $\mathrm{x}$ & & \\
7 & $\mathrm{x}$ & & \\
\hline
\end{tabular}

Note. The $\mathrm{x}$ indicates which of Domhoff's three indicators of power is addressed by the research questions.

those data sources that answered at least one of the research questions or one of Domhoff's indicators of power were selected to be used in this study. These data sources include official records in the form of affidavits, court depositions and court transcripts; in addition to newspaper articles from the four local newspapers.

The court depositions were taken from the following four persons:

1. George Allen, a private attorney who filed two desegregation lawsuits against Broward County schools, resulting in settlement agreements in 
Table 8

Research

questions

Domhoff's

power

indicators

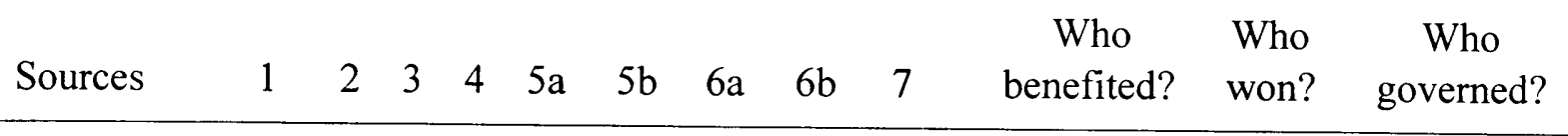

Affidavit

$\mathrm{x}$

$\mathrm{x}$

Court

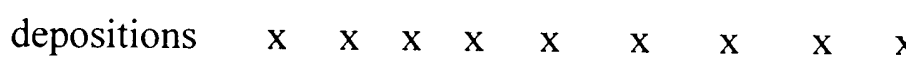

$\mathrm{x} \quad \mathrm{x}$

$\mathrm{x}$

Court

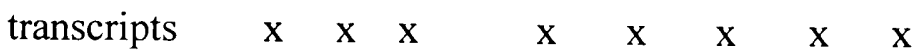

x $\quad \mathrm{x} \quad \mathrm{x}$

Newspaper

articles

$\begin{array}{lllllllllllll}\mathrm{x} & \mathrm{x} & \mathrm{x} & \mathrm{x} & \mathrm{x} & \mathrm{x} & \mathrm{x} & \mathrm{x}\end{array}$

$\mathrm{x}$

$\mathrm{x}$

$\mathrm{x}$

Note. The $\mathrm{x}$ indicates which of the research questions and Domhoff's three indicators of power is answered by the archival data sources.

1970 and 1987. Attorney Chris Fertig in the Washington, et al. case in

1994 took his deposition. This was a desegregation lawsuit filed against

Broward County schools.

2. William Dandy, a retired, high-ranking black School Board official, who

was considered the guardian of desegregation in Broward County and the

architect of the 1987 desegregation settlement agreement. He was

deposed in 1994 under the same circumstances as Allen. 
3. Edward Marko has had an uninterrupted career with the Broward County School System as its attorney and advisor on desegregation issues since the 1970 lawsuit was filed until the present. He was also deposed in the Washington case in 1994.

4. Lee Stepanchek is the last deponent. Since 1984, she has held several administrative/management positions with Broward County schools dealing with desegregation issues, which include identifying and purchasing sites for new schools to be built, and establishing attendance boundaries. She was deposed in September of 1994 in the Washington case and in February and April of 1997 in the Citizens Concerned About Our Children case.

Attorney George Allen was the affiant in 1997 in the Citizens Concerned About Our Children lawsuit. One transcript was from Smith vs. McFatter in February 1995 when School Board Attorney Marko and Attorney Allen went to court to request $\$ 4,000$ in attorney fees for Mr. Allen who provided consultation services to the School Board. The second transcript is from Washington, et al. vs. Broward County, in April 1995. The newspaper articles are from The Broward Times, The Miami Herald, Sun-Sentinel and Westside Gazette newspapers, from 1991 to 2000.

Description of Researcher's Role

This section documents the researcher's experience with school desegregation in Broward County, Florida. Over the past 23 years, this researcher has been actively 
involved in the issue of school desegregation in Broward County, Florida and has tried to understand the elements of power as they relate to this issue. The author's involvement as the researcher has sometimes been as a participant observer and at other times as a non-participant observer. This experience placed this researcher in the invaluable position of helping to establish external and internal criticism of data sources and helped with identifying and locating corroborative data sources. The researcher was able to put her primary data sources through the test that Gay (1996) proposed, which is to assess for knowledge and competence, immediate and/or direct involvement in an event or occurrence, biased motives and consistency of information reported (Gay, 1996).

The researcher's interest in the topic of power and school desegregation in the Broward County School System spans almost two decades. She has worked in over 30 different schools in Broward County as a School Social Worker-most frequently in the central and northern parts of the County. Some of the schools were located in predominately white, upper middle-class and affluent communities. Some of the schools were in low-income, predominately black communities and other schools were in working/middle-class, racially and ethnically mixed communities. This researcher has had the advantage of working in schools from which black children were starbursted (bused), and those schools to which they were starbursted (bused).

The role of a School Social Worker is to be the liaison among the school, home and community. The School Social Worker make many visits to the homes of students, 
which provides one with a deeper understanding of students and their families, and the social and systemic issues that adversely affect their lives.

The following is a list of issues on the topic of school desegregation that had their underpinnings in the 1987 Consent Decree, and therefore, involved School Board policies and practices on desegregation.

1. A high number of black children were bused into predominately white schools compared to the low number of white children bused into predominately black schools.

Parents often asked School Social Workers when making home visits, why their children were being bused when white children were not being bused to their schools? In some situations students were bused into schools already over-enrolled, and in other situations, they were bused from schools that were under-enrolled. Table 9 shows the disparity in the number of black and white children bused for purposes of desegregation.

During the implementation of the desegregation plans, the Broward County School Board never drew boundaries for Coral Springs students to attend school outside the city limits of Coral Springs. Local and national advertisements from Coral Ridge Properties promoted Coral Springs as a self-contained community with quality living. The advertisements guaranteed "neighborhood schools" and "quality education." The following scenario is an example of the disparity in the busing of black and white children.

School A, to which black children were starbursted, was located in a predominately white, middle-class community. School B served a community that was 
Table 9

Disparity in the Number of Black and White Students Bused to Desegregate Schools

\begin{tabular}{llcc}
\hline & \multicolumn{1}{c}{$\begin{array}{c}\text { Number } \\
\text { of } \\
\text { Bused }\end{array}$} & \multicolumn{2}{c}{ Percentage } \\
\cline { 3 - 4 } & Students & Black & Non-black \\
\hline To magnet programs & 5,000 (approx.) & 29 & 71 \\
$\begin{array}{l}\text { From non-contiguous } \\
\text { boundaries }\end{array}$ & 7,000 (approx.) & 91 & 9 \\
$\begin{array}{l}\text { For desegregation } \\
\text { Total bused } \\
\text { in district }\end{array}$ & 12,000 (approx.) & 66 & 34 \\
\hline
\end{tabular}

Note. Information is for school year 1993-94. Students bused for desegregation are non-magnet students. Information taken from an internal memo of the school system (Art Whitman to William Dandy, April 2. 1991).

approximately one mile in radius. It was within walking distance of a group of approximately 30 black children who were bused seven miles to School A.

A black Social Worker was assigned to School A. The predominately white staff frequently and consistently sought the black Social Worker's assistance and expertise in working with the bused children and their families and in helping them to develop a better understanding of the social situations of the families.

The staff reported that the children appeared angry and aggressive. Therefore, this became the targeted behavior when the Social Worker began to work with these students. When the Social Worker met with the fourth and fifth grade students, they 
expressed anger. Paraphrasing their comments, they said, "we don't know why we can't go to the school that's in our neighborhood. Why do we have to come all the way over here?" They did not want appeasement, they wanted a logical answer, and they wanted the Social Worker to help them attend School B (their neighborhood school). When the Court declared starbursting illegal in the Washington case in 1995, and parents were given the option to have their children attend their neighborhood school or continue to be bused to School A. All the children bused to School A chose to attend School B.

2. There were frequent demands for black parents to visit the schools (to which their children were being bused) for conferences. The topics usually fell into the following categories: placement of their children into special education programs, behavior problems, poor academics and/or low achievement.

Many of the white teachers and administrators made it very clear to the School Social Worker that they did not understand the black children who were coming to them, neither did they want them in their school(s). In many of these schools, black students, mostly boys, were the major population in the special education classes. The predominately white staff did not relate very well to the black children being bused into their schools. Therefore, the staff were not very effective in teaching and disciplining them. This led to the staff having to contact the parents to intervene. Many of the actingout behaviors of students - as described by teachers and administrators - were absent at home and surprising to the parents.

Many black parents shared with the School Social Worker that they felt their children were placed in special education classes because the teachers and administrators in those schools did not know how to teach and discipline their children, rather than 
because they deserved to be there. It was a common belief among black parents that black children were placed in special education classes or programs to generate additional money (funding) for the School System. This combination of assumptions by parents resulted in many parents responding to requests for conferences and the evaluation of their children in a reticent manner. This response by parents was usually interpreted negatively by school-based staff. It indicated to them that the parents were uncooperative, unconcerned and negligent parents and did not value education.

Table 10 illustrates the high number of black students in classes for the mentally retarded, in contrast to the low number of black students in gifted programs, and Table 11 shows the disparity in the suspension rate of black and white students.

3. Black parents did not have transportation to get to the schools to which their children were bused and in many cases, they did not know where the schools were located.

The School Social Worker made a home visit to an apartment complex in Collier City, a predominately black, low-income community in Pompano Beach, Florida. The apartment was full of children being cared for by their grandmother, who explained that Health \& Rehabilitative Services (HRS), now the Department of Children and Families (DCF) had placed three different sets of grandchildren in her custody. The grandmother appeared frazzled and overwhelmed, and was having a difficult time managing the children. When the Social Worker explained that the school had sent several notices to her to attend conferences to discuss the results of her grandson's psychological testing and possible placement into a special education program, she responded in the following 
Table 10

Students in Special Education Classes or Programs

Program

White

Black

$\mathrm{EMH}$

343

811

$\mathrm{TMH}$

226

285

GIFTED

4,030

382

Note. $\mathrm{EMH}=$ Educable mentally handicapped, the mildest form of retardation indicates an I.Q. of 52-69.

$\mathrm{TMH}=$ Trainable mentally handicapped indicates an I.Q. of 36-51 and Gifted is at the opposite end of the extreme indicating an I.Q. of 130 and above. Students with a status of minority, ESOL or free and reduced lunch could qualify for the Gifted program with a 115 I.Q. based on Plan B criteria, which considered criteria other than I.Q. Information is taken from the Desegregation Task Force Report (1995) for school year 1993-94.

Table 11

Suspension Rate Difference for Black Students Compared to White Students

\begin{tabular}{lcccc}
\hline & \multicolumn{2}{c}{$\begin{array}{c}5 \text { points } \\
\text { or greater }\end{array}$} & \multicolumn{2}{c}{$\begin{array}{c}10 \text { points } \\
\text { or greater }\end{array}$} \\
\cline { 2 - 5 } $\begin{array}{l}\text { School } \\
\text { level }\end{array}$ & $\begin{array}{c}\text { Number } \\
\text { of schools }\end{array}$ & $\begin{array}{c}\text { Percent } \\
\text { of schools }\end{array}$ & $\begin{array}{c}\text { Number } \\
\text { of schools }\end{array}$ & $\begin{array}{c}\text { Percent } \\
\text { of schools }\end{array}$ \\
Elementary $(n=112)$ & 1 & .9 & 0 & 0 \\
Middle $(n=31)$ & 22 & 70.9 & 17 & 54.8 \\
High $(n=22)$ & 16 & 72.7 & 7 & 31.9 \\
\hline
\end{tabular}

Note. Source: Florida School Report, 1992-93.

manner: "I'm doing the best I can with these children. I have the children of three of my

daughters, I don't know where they are, and they are out there on that stuff (crack 
cocaine). I can't keep running out to that school. The last time I went to that school I had to pay a taxi $\$ 20.00$ and didn't have enough money to buy these babies milk. Tell those people to do whatever they want to do with my grandson, cause I can't come out there." The School Social Worker also discovered that the grandmother could not read or write.

Another incident occurred in a different school, when a little boy became ill at school and the school made a call to the emergency phone number on the child's registration form. The family did not have a telephone. The grandparents, with whom the child lived were slow to respond, so the School Social Worker was asked to make a home visit. When the Social Worker arrived at the home, the elderly grandfather was mounting his bicycle to go to the school to pick up his grandson. He was not aware of the specific location of the school, which was located about five miles away, tucked away in a residential neighborhood. The grandfather would have had to ride his bicycle on a major highway and cross the intersection of Interstate 95. It probably would have taken him close to an hour travel time in each direction. The return trip would have been even more dangerous with a sick child on the bicycle.

Another incident occurred in School A, which was previously mentioned in the first scenario. The school was trying to meet a deadline for placing a child into a special education program so they could receive funding. The mother's written consent was required. Several conferences had been scheduled, but the mother had missed all of them. Her phone was disconnected. When the School Social Worker made a home visit, she discovered that the single mother had several minor children and had been recently 
released from the hospital following major surgery. She was confined to a wheelchair due to amputation of a leg. She had no personal transportation and they lived seven miles from the school. Public transportation required taking three buses and would have required one and a half-hours travel time in each direction.

4. Negative stereotypes, attitudes and the indifference of staff at predominately white schools was displayed toward the black children and their parents.

One day a School Social Worker received a phone call from a black Guidance Counselor at Coral Springs Middle School. Coral Springs is an affluent, predominately white community in northwest Broward County. The Social Worker had recently assumed the position of Chairperson of the Education Committee for the Fort Lauderdale NAACP. This was the Social Worker's and Guidance Counselor's first contact with each other; but there would be numerous contacts after that. The Guidance Counselor was a relentless advocate for and guardian of the black children bused into Coral Springs Middle School from the predominately, low-income, black community of Collier City, in Pompano Beach. The Guidance Counselor explained that there was growing enmity between the black students from Collier City and the white students from Coral Springs. One day, when the buses arrived, some white Coral Springs students had been overheard saying, "here come the jungle bunnies." Collier City students had started to assault the Coral Springs students, and there had been a couple of physical incidents between Coral Springs and Collier City students. The Guidance Counselor was afraid a riot was imminent. 
The NAACP president (Carlton Moore) and the School Social Worker decided to meet with the principal to discuss the situation. He, too, was concerned; however, he did not know what to do. He appeared honest and forthright, and shared some illuminating thoughts with them.

He appeared sympathetic toward the students from Collier City. He said that not only are they black, they are also poor. At that time, Coral Springs had a small, black residential population. Many of the blacks were from the Caribbean. He ventured to say that the Collier City students were out of place at this school - they did not fit in and they had no real allies. The white students rejected them because they were black. The black students from Coral Springs rejected them because they were poor and also from a different cultural background from the Caribbean students living in Coral Springs. The really insightful message was that the few black teachers, most of whom lived in Coral Springs, did not connect with or want to be associated with the Collier City students either. With the exception of the Guidance Counselor who called the Social Worker for help, the black students had little or no support system at Coral Springs Middle School.

5. There were a low number of black teachers at predominately white schools, and they seemed fearful or reticent to be seen associating with another black person.

In predominately white elementary schools, there were rarely more than two or three black teachers out of 25-30 teachers on staff. The black Social Worker observed a pattern of behavior such that she would approach the black staff and they would shy away and avoid her. In one predominately white elementary school, during her weekly 
visits to the school, a black Social Worker would stop by the classroom of a black teacher to say, "hello." The black teacher had previously given the Social Worker a referral on a black student who was bused into the school. The Social Worker noticed that the black teacher would appear to be nervous and appeared careful that none of the white staff saw them talking to each other. She seemed reluctant for them to acknowledge each other when they encountered each other in the school. The teacher shared with the Social Worker that when two blacks get together, the white people become concerned. The Social Worker eventually stopped visiting her.

6. Good, competent and effective black teachers had a difficult time obtaining transfers to work in predominately black schools.

The School Social Worker learned through personal discussions with black teachers, (some of whom were friends and acquaintances) that they were eager to work in predominately black schools. Their requests were denied year after year. Many of these teachers were the "cream of the crop." They knew they were excellent teachers, and felt their skills, talents and expertise could be better utilized and were more needed in inner city schools. These teachers, as the teacher mentioned above, felt isolated and imprisoned in these predominately white schools.

Through inquiry, the Social Worker discovered that there was a minimum quota that determined the placement of black teaching and administrative staff in all Broward County public schools based on the 1987 Consent Decree. Most of the predominately white schools hired the minimum number of black teachers. In other words, if they did 
not have to hire black staff they did not. The best and the brightest black teachers were taken away from predominately black schools and placed in white schools.

7. Teachers who had problems in predominately white schools or who were moved for incompetence were routinely placed in predominately black schools.

Some principals and teachers in predominately black schools became aware of the Social Worker's involvement with the NAACP and her interest in issues regarding equity in education. This gave them the confidence to express their complaints and concerns without fear of reprisal. They shared, in confidence, the phone calls and visits they received from area and district School Board administrators informing them that certain teachers and support staff would be transferred to their schools. They stated that they felt powerless and were afraid to object or to inquire as to why. It was not unusual for them to subsequently learn that these individuals had problems in another school, usually a predominately white western school. The reverse did not occur as readily. It was almost impossible for a principal in a predominately black school to get a poorly performing teacher moved (except for a serious infraction like committing a felonious act), especially if the teacher was white.

8. $\quad$ Principals in predominately black schools were forced to hire white teachers without giving consideration to their level of competence or effectiveness. White teachers were granted full-time jobs with all accompanying benefits, while principals could only hire black teachers as substitutes who received no benefits.

Another consistent complaint of principals in predominately black schools was that they were forced to hire white teachers at the expense of more competent black teachers. In one of the traditional black high schools in Broward County, 90 percent of 
the teaching staff was white and 90 percent of the student population was black. The School Social Worker was told by a secondary source that the highest-ranking black administrator in the School System (at the time) rationalized that less criticism would be lodged against the school if the majority of the school staff were white.

Because there was such a high turnover of teachers in predominately black

schools, some principals developed the strategy of: hiring teachers as substitutes; observing their performance; and offering permanent positions to those who appeared competent and effective. Many of the teachers selected for permanent positions were black, but principals were forbidden to hire them. They could only use them as substitute teachers who received no benefits. Some of the principals informed the Social Worker that the area and district offices would force them to hire whatever white teachers were sent to them whether the teachers were competent or not.

The principals and black teachers in those schools reported that many of the white teachers were not competent. Little teaching and learning took place in their classrooms because they had poor control and management of their classrooms. Principals were forced to retain them anyway. Principals found themselves almost depleting these classrooms by dispersing the most active students among other teachers. This caused resentment amongst teachers because some teachers had twice as many students as other teachers. Some of the teachers who received additional students were the black substitute teachers who were denied permanent positions. 
Another serious problem that was created by these practices was the high number of substitute teachers in predominately black schools. Some students missed a half-year or more of learning because of the lack of continuity in instruction. Principals were forbidden to hire permanent black teachers and substitute teachers would come and go at these schools. Some classes would have as many as ten different teachers in one school year. The students would not know if they would have the same teacher today as they did the day before. Nor did they know if their class would be separated and the students dispersed to different teachers because no substitute could be found for that day.

In a predominately black school Innovation Zone (a cluster of elementary and middle schools that feed into one high school) that had a high number of vacant teaching positions, the principals attempted to discuss this issue with their area superintendent and to elicit his support against the unwritten policy and practice that prohibited them from hiring competent teachers in permanent positions because they were black. Several principals conveyed to the Social Worker that they were told to "shut up" and not to pursue this issue with anyone else. As a result, the principals discreetly passed this information on to members of $\mathrm{CCC}$, who met with the highest-ranking black official in the School System. He admitted to this unwritten policy and practice of the School System and attempted to rationalize it. CCC members insisted that such policy and practice was responsible for a constellation of problems. Many black children were not being educated properly. They were being mislabeled, placed in special education classes, and suspended. The CCC demanded an immediate end to this policy and 
practice, declaring it to be discriminatory, unfair, and denying employment opportunities to qualified black teachers.

Another example of this practice occurred when a predominately black elementary school needed a speech teacher. There was a shortage of speech teachers in the school district and the principal was willing to share a speech teacher with another school. A person was interviewed and accepted the position, but the principal was not allowed to hire this person because she was black, and no white person had applied. The students in this school were denied speech therapy services for half a school year.

9. There was silence on the part of black teachers and administrators regarding the biased and discriminatory practices and attitudes toward black children and their parents.

The Broward County School System seemed to have done a better job of integrating staff than of integrating students. In all the predominately white secondary schools, there was at least one black administrator and support staff person. Many of them seemed disconnected from the black children in those schools. They appeared no more concerned or sensitive to the plight of black children and their families than was the white staff.

When black staff were amongst other black people and away from the gaze of white people, they felt free to openly and vigorously condemn the School System for being racist, discriminatory and unfair. They expressed criticism of the high suspension and failure rate of black children and the disparate number of black children in special 
education programs. They spoke about the biased attitudes of their colleagues toward black children and the unfair treatment of black children.

Black children in those schools had few no allies. Outside of school, the issues plaguing black children were interesting topics of conversation for black professionals. Inside the school, the black professionals distanced themselves from the issues.

10. Starbursting imposed hardships upon many families, especially those in which single parents and grandmothers were raising the children.

The Team Leader for School Social Workers received a phone call one day from a fellow Social Worker, seeking consultation on a case regarding four siblings from the same family attending a predominately black elementary school in Fort Lauderdale. The Social Worker explained to the Team Leader that the principal was demanding she take the mother to court for failing to send her children to school.

The Team Leader spoke to the mother, principal and an area administrator and discerned the following. Prior to Christmas break, the mother moved from her father's home, which was around the corner from Martin Luther King Elementary into the boundary of Northside Elementary, which was also predominately black, and about seven miles away. The mother worked until 7:00 PM and made arrangements for the children to walk to her father's house (their grandfather's) after school, where they remained until she picked them up around 8 PM every night.

The mother and the principal had a confrontation. When the principal discovered that the mother had moved into the boundary of another school, she withdrew the children and insisted that the mother enroll them into Northside Elementary, their new 
home school. The mother refused and continued to send her children to Martin Luther King. The principal eventually refused to allow the children into the school. The area administrator supported the principal's position of not allowing the children to attend Martin Luther King, and also insisted that the mother be taken to court.

School Board policy not only stipulated that children must attend the school for the address of the legal parent or guardian, but students must be enrolled in and attending their assigned school in order to be considered for reassignment. The mother argued this was unreasonable for her, because she had no child care provisions in the Northside Elementary community. The after-school childcare programs closed at 6:00 PM. Her father was elderly and did not have transportation.

The dispute between the school and the mother continued through the school year; therefore, the children were out of school for the remainder of the year, which was more than a semester.

11. The School System was inflexible about modifying its policy on student assignment and insensitive in addressing and acknowledging the human element.

In order to comply with the 1987 Consent Decree, the School Board enacted what is referred to as a policy on "Attendance Boundaries, Assignments, Reassignment of Students and Enforcement of Attendance Rules" - School Board Policy 5001.

The assignment of students to schools according to this policy was based on the address of the parent or legal guardian. The intent of this policy was to foster student desegregation in the School System, and to make it difficult for white parents to 
circumvent sending their children to predominately black schools. However, the effect of this policy adversely affected black children, their families and the community.

The following is an example of how this policy negatively impacted black students. The School Social Worker was asked to intervene in an attendance case. A young single mother living in a low-income, black community in Pompano Beach had a four-year-old attending the Headstart program at Drew Elementary (a school that was 100 percent black) in Collier City. She had a five-year-old attending their neighborhood school, Markham Elementary, which was about 98 percent black. She had an older elementary school child who was bused to and from her school to attend a cluster program for special education students, and who was dropped off in the afternoon at the baby sitter's home, in Collier City. This baby sitter walked to Drew Elementary every day (just a few blocks away) to pick up the four-year-old child. The mother had to make arrangements to pick up the five-year-old child, because there was no bus transportation near the baby sitter's home and Markham Elementary was too far for the baby sitter to walk to pick up the five-year-old. The mother worked 10 to 15 miles away in another county.

The five-year-old was constantly being picked up late, and the School officials began to complain. The mother explained that she took a late lunch so she could drive the 10-15 miles to pick up the five-year-old from school and drop her off at the baby sitter's home. Her car was in disrepair and had broken down several times. She was trying to liberate herself from welfare and really wanted this to work. The School Social 
Worker helped the mother to complete the reassignment papers for the five-year-old child to attend Drew Elementary. The four-year-old already attended Drew Elementary where it was convenient for the baby sitter to pick-up both children after school. The reassignment request was denied. The rationale given was that if they granted this reassignment then white parents could come up with any flimsy excuse to get their children assigned out of black schools. The mother eventually had to quit her job and go back on welfare.

Another example was indicated by a single mother of five living in the Crystal Lakes housing development in Hollywood. She reported on how the School Board's student assignment practice affected her children and her community. As President of the Tenants Association, she worked with her children, and the other children in the development to keep them out of trouble and to quell disturbances between them. In doing so, she discovered there was rivalry between the children in this development based on what school they attended. The development consisted of 22 different buildings. The middle school children in buildings one through eleven were assigned to Olsen Middle School and the children in buildings 14 through 22 were assigned to Attucks Middle School. The conflict between the children appeared normal and harmless at first when they began to compete over whose school was best at athletics and academics. It gradually became more serious as the children began to develop gang membership based on the school they attended. The elementary school children from the 
development were all bused to predominately white Sheridan Hills Elementary, even though Bethune Elementary was their neighborhood school and within walking distance. The parents in this development, and in the immediate community were outraged because Bethune Elementary had a high quality magnet program that the neighborhood children could not attend. Although Bethune Elementary was located in the heart of the black community, it was 70 percent white, the black children in the immediate community were denied enrollment and bused out to several predominately white schools to integrate them.

In some communities, children living next door to or across the street from each other were assigned to different schools. Some of these children were part of an extended family and shared a common support system, which made it difficult for families to function.

A tenth grade student tearfully recounted this experience several years ago. She lived in the low-income, predominately black community of Collier City in Pompano Beach, just a few blocks from Drew Elementary. For five years, she had attended Drew Elementary with extended family members. They were somehow able to elude the School Board because their assigned school was Margate Elementary, five to seven miles away. She loved Drew Elementary, was the President of the Student Council, and participated in everything she could. Her grades were good and she was thought to be one of the smartest and most promising students in the school. 
Her younger brother was involved in a fight one day and fractured the arm of another student. The principal discovered they lived within the boundary for Margate Elementary and summarily withdrew the entire family. Some family members were able to remain even though they lived in the same neighborhood, because they lived on different streets. This young girl was vocal and forthright. She pleaded with the principal to allow her to stay the remaining two months of school. She argued that it was not fair for her to be punished for something her brother did. Her pleas were ignored. She could not understand why the children who lived on her side of the street were assigned to Margate Elementary and the children who lived on the other side of the street were assigned to Drew Elementary.

She talked about how sad and depressed she was at the new school. She cried frequently, performed poorly in class and received failing grades in all of her subjects. She never quite recovered from that experience.

12. The high mobility rate of students living in mostly inner city communities was caused, in part, by starbursting.

The School Board's practice of starbursting black students contributed significantly to the mobility rate of students. It was not uncommon to pick up a student's Cumulative Record folder in elementary school and find several schools listed. In general, there is a high level of mobility in low-income communities; however, these people usually move within their immediate communities.

With the practice of starbursting, a group of children living within the same twomile radius could be assigned to as many as nine different elementary schools. 
Therefore, if a family moved within this two-mile radius several times during the elementary school life of the children in the family, the children may have been placed in the boundary of a different school each time the family moved.

The School Board conducted a study on student mobility and determined that students who attended more than one school within a school year were not as successful as students who attended one school for an entire school year (School Board of Broward County, 1995). As a matter-of-fact, the failure rate of those students was very high.

The School Social Worker at Walker Elementary received a referral to conduct a home visit to obtain a grandmother's consent to evaluate her granddaughter. The child was in the fifth grade and the evaluation process had started in second grade. Because she had been enrolled in eight different schools, her length of stay in one school was not sufficient for the evaluation process to be completed. This child was far below her academic level and had some serious behavior problems. It could not be determined if her lack of academic progress was due to intrinsic learning difficulties or because of the lack of continuity in her education and her frustration with her educational program as a result of having attended so many different schools.

The grandmother's address given to the School Social Worker was incorrect. In tracking down the grandmother, the Social Worker discovered that she lived down the street from the neighborhood school, but within the boundary of another school. The children in this neighborhood (that was about one mile in radius) were assigned to six different elementary schools. 
The Social Worker visited with the grandmother who had some personal health problems for which she was being treated. She attributed her granddaughter's lack of progress to her attending so many different schools. In addition to the school-age child, she had custody of other grandchildren - a couple of whom were toddlers. The grandmother pleaded with the Social Worker to allow her granddaughter to remain at her current school. She said it was more convenient for her to attend conferences and to pick up her granddaughter when she became disruptive. She said when her granddaughter attended all those other schools so far away; it was difficult for her to get there, and to cooperate with the schools.

\section{Summary}

Chapter III is a presentation of the method applied to collect and analyze the data for this research study. This is a historical case study on power and the Broward County School System and desegregation from 1970 to 1998.

The historical case study approach is the most appropriate research method for conducting this study because the case study method is generally employed when the researcher is seeking a better understanding of a particular case. Historical documentation is used to uncover answers to unknown questions; to examine relationships; and to evaluate the past activities of people, agencies or institutions. This researcher attempted to provide greater insight into the issue of desegregation in Broward County and the power relationship between the School Board and community. The 
historical case study method is also a common research method that has been utilized by many other researchers when conducting research on school desegregation.

Data collected in this research study were from 11 participant interviews and various sources of archival data. Two-hour interviews were held with each of the participants, between September 2001 and September 2002. Only one person did not consent to having their interview audiotaped. The participants included persons directly involved in school desegregation issues as either School Board officials (5) or community activists (6). The archival data sources included an affidavit, four court depositions, two court transcripts and newspaper articles from four local newspapers from 1991-1999.

All the interviews were transcribed and the data placed on a grid. Matrixes were created of the 15 interview questions and cross-referenced with the nine research questions. The nine research questions were also cross-referenced with Domhoff's three indicators of power. The same process was applied to the archival data sources.

A frequency count was performed based on how each of the data sources (interview and archival) responded to the research questions and to Domhoff's three indicators of power. A single count of one (1) was given regardless of how often a participant may have addressed any of the research questions or Domhoff's indicators of power.

The researcher's interest in the topic of power and school desegregation in the Broward County School System spans almost two decades. She has worked for the Broward County, Florida School System as a social worker for the past 23 years. She has 
worked in over 30 different schools in Broward County. Some of these schools were the source of the black children who were starbursted (bused) and other schools were the recipients of the black children who were starbursted (bused).

The researcher presented a list of scenarios that stimulated her interest in the topic of school desegregation and were based on her actual experience as a school social worker. All of the issues and examples had underpinnings in the 1987 Consent Decree and, therefore, involved School Board policies and practices on desegregation. 


\section{CHAPTER IV}

\section{FINDINGS}

The purpose of this Chapter is to present and analyze data collected in this historical case study on desegregation and power in Broward County, Florida from 1970 to 1998. The chapter is organized in the following manner. A brief introduction is provided regarding the purpose of the study and of Chapter IV. Next, data are presented for each of the study's research questions. More detailed information for questions one, three and six is provided in Appendix B, C, and D. The Chapter concludes with a summary.

The purpose of this study is to describe, explain and analyze types and uses of power by the School Board of Broward County, Florida and community activists, in their efforts to influence desegregation from 1970 to 1998.

The issue of power is explored in the context of school desegregation to determine how power was historically used and manifested in desegregation decisions in Broward County. Three dimensions of power are explored: Who benefited and who won from the School Board's desegregation policies and practices and who governed those policies and practices?

\section{Presentation of Data}

\section{Responses to Research Questions}

Research questions $1,5 \mathrm{a}$, and 7, are important because they helped to answer, in part, all three of Domhoff's indicators: Who benefited, who won and who governed? Questions 2, 3, and 4 primarily answered who governed? Questions $5 \mathrm{~b}$ and $6 \mathrm{~b}$ answered who benefited. Question 6a primarily answered who benefited and who won? There 
were similar responses or no differences in the responses given to the questions of who benefited and who won? Therefore, these two questions are grouped together.

Research question \# 1: What are the factors that made school desegregation an important power issue in Broward County? The responses to this question fell basically into three categories (See Table 12 and Appendix B).

1. Issues related to the busing of students

2. Issues of equity in facilities, resources, courses and education

3. Segregation and resegregation of schools

Issues related to the busing of students and of equity by far seem to be much more of a concern than issues regarding the segregation or resegregation of schools. Fourteen out of possible 21 data sources (interviews and archival data sources) mentioned busing as an important issue of power. Eleven data sources mentioned equity as an important issue of power as opposed to only three who mentioned the segregation and resegregation of schools as an important power issue.

The burden of busing of students for purposes of desegregation was said to be unduly placed on black children. It was stated that a disproportionate number of black children were bused to far away white schools where they were mistreated and only black children were starbursted. This was described as a very disruptive, destructive, and harmful form of busing that destroyed neighborhood cohesion. Busing was said to be inconvenient for students, and for black parents who were unable to attend PTA and advisory meetings or school conferences, because they did not have transportation. Black students could not participate in after-school activities for the same reason. Busing was also thought to create white flight, and created division between the races. Black children 
Table 12

Research Question \#1: What are the Factors that made School Desegregation an Important Power Issue in Broward County?

Frequency

Factors

Participant

Archival

interviews

data

Issues related to the busing of students

9

5

Issues of equity in facilities, resources,

8

3

courses, and education

Segregation and resegregation of schools

2

1

Note. Frequency of responses is based on interviews with 11 participants and 10 sources of archival data.

were also bused to predominately black schools rather than allowed to attend their own neighborhood schools, while white children in affluent, western communities were not bused at all.

Research question \#2: Who were the principal players who governed the School Board's desegregation policies and practices?

Names were given for people inside and outside the School System. As shown in Table 13, the principal players inside the School System were Dandy, Sterling, and Marko. Dandy was mentioned as a principal player by about half of the data sources (10). Sterling, by six and Marko by five.

The principal players in the community were Allen, Boursiquot, Price and Fertig. Allen was identified as a principal player by slightly more than half the data sources (12). 
Table 13

Research question \#2: Who were the Principal Players Who Governed the School Board's Desegregation Policies and Practices?

\begin{tabular}{llc}
\hline & \multicolumn{2}{c}{ Frequency } \\
\cline { 2 - 3 } Principal Players & $\begin{array}{c}\text { Participant } \\
\text { interviews }\end{array}$ & $\begin{array}{c}\text { Archival } \\
\text { data }\end{array}$ \\
\hline School Board staff $(n=8)$ & & 1 \\
Bill Dandy & 9 & \\
Neil Sterling & 6 & 4 \\
Ed Marko & 5 & \\
Margaret Roach & 2 & \\
Lee Stepanchek & 2 & \\
Ray de la Fueilliez & 2 & \\
Boundary Committee & 2 & \\
Jan Cummings & 2 & \\
All superintendents, but particularly (n=5) & & \\
Sam Morgan & 4 & \\
Bill Drainer & 3 & \\
William Leary & 2 & \\
Bill McFatter & 2 & \\
Frank Petruizelo & 2 & \\
George Allen & 3 & \\
Janice Boursiquot & 2 & \\
Ernestine Price & 6 & \\
Chris Fertig & & \\
Mary Fertig & & \\
Art Kennedy & & \\
Alcee Hastings & & \\
Carlton Moore & & \\
Ali Waldman & & \\
\hline
\end{tabular}

Note. Frequency of responses is based on interviews with 11 participants and 10 sources of archival data. 
Six data sources mentioned both Boursiquot and Price as principal players. Chris Fertig was mentioned by four, Mary Fertig and Art Kennedy by three.

All of the principal players who governed desegregation policies and practices were described in Chapter III - under participants, with the exception of Marko and Boursiquot. Marko has provided legal representation to the School Board since the 1970 desegregation lawsuit was filed, and continues to do so. Boursiquot is an education advocate and was involved in desegregation issues in her role as Chairperson of the NAACP's Education Committee and consultant to the state, regional and national NAACP offices and to the attorneys for Citizens Concerned About Our Children (CCC).

Research question \#3: What were the power techniques used by the principal players to influence desegregation policies and decisions? (See Table 14).

In Chapter II, several theoretical models of power were presented. Based on the data collected, the power techniques used did not fit completely into any particular model. However, aspects of three of the different models (Russell, Galbraith and Wartenberg) were used by School Board officials and by community activists.

Power Techniques Used

\section{Russell: Power Over Opinions}

In the review of literature, Russell talked about seven different forms of power (priestly power, kingly power, naked power, revolutionary power, economic power, power over opinions, and power of creeds as sources of power). Russell described "power over opinions" as perhaps the most important and potent form of power. He said that all other forms of power emanated from here. The exercise of all the other forms of power will be weakened without the power to influence, persuade, coerce and 
Research question \#3: What were the Power Techniques Used by the Principal Players to Influence Desegregation Policies and Decisions?

Frequency

Power techniques used

Participant

Archival

interviews

data

School Board officials

Russell - Power over opinions

10

8

Galbraith-Compensation

10

7

Wartenberg - Coercive force

5

7

Community

Wartenberg - Coercive force

4

3

Russell - Power over opinions

1

2

Galbraith - Compensation

Note. Frequency of responses is based on interviews with 11 participants and 10 sources of archival data.

manipulate, which is what "power over opinion" does. This is discharged through the recitation of thoughts, ideas, information and the promotion of propaganda (Russell, 1938).

School Board officials. Both the community and School Board officials seemed to engage in techniques that apply to "power over opinions." However, "power over opinions" seemed to be the primary technique of power used by School Board officials to influence desegregation policies and decisions. Table 14 reveals that 10 out of the 11 
participants interviewed and eight out of ten archival data sources mentioned - at least once - the use of this technique by School Board officials.

The School System's technique of influencing opinions was more subtle than that of community activists. The School Board used the media in a more official capacity than did the community. The School Board created a Public Relations Department, which developed and disseminated official reports, wrote speeches for School Board officials and created press releases. All of the foregoing were used to refute negative criticisms of the School System, and to present the School System in a positive manner.

One such official report was the Position Papers (Broward County Public Schools, 1997) which was developed to counter CCC's allegations of inequities in the School System and to garner support for the School Board's penny sales tax to build new schools. In this report, the School Board refuted CCC's specific claims by asserting that eastern schools had, in fact, received more capital dollars than western schools. The same report stated that the School Board had been proactive in ensuring diversity and eliminating starbursting; that through a collaborative process with the community, it ended starbursting a year early.

School Board officials made statements to the press and met with the editorial boards of the local newspapers and television stations. The School Board was also able to state its opinions on issues regarding desegregation during the many School Board sponsored public meetings and hearings, which were usually attended by the press.

School Board Attorney Marko indicated to the Judge in Court transcripts that he and Allen phrased things a certain way in the settlement agreement and in other School Board documents to the federal government in order for the School Board to obtain 
federal funds. (Washington, et al., vs. Broward County, 1995b; Smith vs. McFatter, 1995). Even the judge in the April 27, 1995 transcript accused the School Board of misleading the community by giving the impression that they were ordered by the Court to do the things they were doing with desegregation. The judge called this a "hoax," saying that the School Board was using the Court to hide behind when they needed to make unpopular decisions. (Washington, et al., vs. Broward County, 1995b). (See Appendix C).

Community. Table 14 shows that the community also employed the technique of "power over opinions"; however, the use of this technique was secondary to the community's use of "coercive force." Only three data sources identified power over opinions as a power technique used by the community.

An education advocacy organization called Citizens Concerned About Our Children (CCC), emerged in the mid 1990s as the major group to address desegregation issues. Prior to that, it was basically the NAACP, and in the late $1980 \mathrm{~s}$, the Inverrary Homeowners Association joined with the NAACP.

All of these groups used the media to disseminate their point of view. CCC was the most persistent, relentless and seemingly effective. Members of the CCC organization wrote newspaper articles that were printed in the local black press. They hurled allegations against School Board officials, singling out School Board Attorney Marko, the Superintendent, the School Board, and Attorney Allen (Citizens Concerned About Our Children, 1995, 1995a, 1995b, 1996, 2000a; Brown, 1995; Price 1995a, 1995b, 1995c, 1995d). In a June 23, 1995, Broward Times article written by Citizens Concerned About Our Children, it accused the School Board of using underhanded 
tactics against members of CCC. They said that the best way to counter sabotage and deception was to expose it. The article stated that the School Board tried to make members of CCC look stupid by confusing and distorting the issues. The article also stated that School Board staff tried convincing the public that the majority of the black community did not agree with or support CCC. (Citizens Concerned About Our Children, 1995a).

Citizens Concerned About Our Children publicly accused School Board staff of manipulating and distorting information, data, policies and procedures (Citizens Concerned About Our Children, 1999). A couple of the participants during the interviews stated that School Board Attorney Marko gave politically acceptable explanations for controversial desegregation issues.

In another Broward Times article (Brown, 1995), CCC stated that the Superintendent reneged on an agreement with $\mathrm{CCC}$ - charging that he promised them one thing in a meeting and later recommended a weakened version of their agreement to School Board members (Kiffin, 1995f; Marks, 1995d). The article also accused School Board Attorney Marko of misrepresenting the facts to the media.

Citizens Concerned About Our Children's use of the "power over opinions" technique was so effective that its public criticism of Attorney George Allen forced him to resign from the Rae Smith case, which ended his 25-year legal reign over desegregation in Broward County (Banker, 1995e, 1995f; Marks, 1995b, 1995c; Price 1995d; Work, 1995). This power technique also helped to defeat the School Board's penny sales tax in 1995 to build new schools (Arthur \& Marks, 1995b; Clayborne, 1995b; Nevins, 1995). 
Citizens Concerned About Our Children also distributed flyers stating its positions, and held a series of meetings and public fora in the community (Citizens Concerned About Our Children, personal communications). The editor of the Broward Times frequently advocated the positions of CCC against the School Board (Clayborne, 1991, 1995c, 1995d, 1995e). There were weekly articles in the local black press, pronouncing and advocating CCC's views. CCC's issues and criticism of the School Board were also discussed on local radio and television stations. The editor of Channel 10 television gave an editorial supporting $\mathrm{CCC}$ against the School Board. In the dominant press and special magazines; articles, editorials, and commentaries were written sometimes daily quoting $\mathrm{CCC}$ members and supporters.

CCC used the power technique of "power over opinions" to influence the School Board's desegregation policies and practices and also accused the School Board of unfairly using the same power technique against them.

\section{Galbraith: Compensatory Power}

In his book, Anatomy of Power (1983), Galbraith theorizes that there are three basic ways in which power is exercised or enforced. He classifies them as condign, compensatory and conditioned power. He then proposes three different sources of power: personality, property, and organization.

Compensatory power appears to be the second most frequent form of power that was used by the School Board, but not used by the community. Galbraith explains that compensatory power is exercised when a person is persuaded to do or not do certain things based on the promise of a reward or payment. In order for compensation to be applied as an effective element of power, this researcher is suggesting that two persons or 
entities are necessary; a person or entity that can provide the reward or payment and a person who is willing to cooperate in the receipt, thereof.

Table 14 shows that compensation was cited in 10 out of 11 interviews and seven out of ten archival data sources as being used by School Board officials. Based on the data collected, it appears that three different entities received compensation from the School System because of their involvement in desegregation issues: Attorney George Allen, William Dandy and the School System. (See Appendix C, compensation). The compensation was in the forms of direct payment, promotions, and power and influence.

$$
\text { Recipients of Compensatory Power }
$$

\section{School Board Staff and School System}

The School System was both a dispenser and a recipient of compensatory power. Galbraith submits that organizations are the most important of the sources of power. He argues strongly that organizations have the power to influence the submission of people, both inside and outside the organizations, to their purpose. Organizations develop mechanisms to ensure the conditioning of their members, because nothing is more effective in threatening the external power of organizations than the "undisciplined expression of dissenting views from within" (Galbraith, 1983, p. 60).

The School System received compensation because School Board staff, such as Attorney Marko, phrased things a certain way in the 1987 Consent Decree and in documents to the federal government; however, they gave a different interpretation when they communicated with the public and with School Board members. Because of this, the School Board was successful in obtaining millions of dollars for the School System (Smith vs. McFatter, 1996b; Washington, et al., vs. Broward County, 1995b). Marko 
indicated in the Consent Decree, and reported to the federal government, that the School System was unitary in order to receive money for magnet programs. On the other-hand, School Board attorney(s) told the Court and the community that the School System was not unitary. Therefore, they could not end starbursting, allow black children to attend magnet programs or allow even one black child to transfer out of a predominately white school or one white child to transfer out of a predominately black school, regardless of the reason. Attorney Marko indicated in his deposition, (Washington, et al., vs. Broward County, 1994b) that the School Board received approximately $\$ 5$ million a year from the federal government by distorting information.

School Board administrator William Dandy seemed to have gained compensation for the role he played in school desegregation issues as well. He indicated in his interview that the School Board was pleased with the way he handled desegregation issues early in his career and he became and remained a principal player during the approximately 40 years he continued in the School System. He was promoted to Deputy Superintendent and was the first black person to hold such a position. Based on statements made by some persons interviewed, Dandy wielded tremendous power, and controlled the favors. Therefore, he got power because of his role in desegregation. He used the Consent Decree to hire more black professionals, and by doing so, built himself a stronger power base. (See Appendix C, compensation).

Some interviewees asserted that not only was Dandy the point person on desegregation in the School System, he was also the spokesperson for education in the black community and people were afraid of him. He held a meeting at his house with major leaders in the black community to put the finishing touches on the 1987 
desegregation Consent Decree. Neil Sterling, School Board member verified Dandy as a principal player in desegregation when he stated that Dandy played a significant role in constructing the Consent Decree and attended all the meetings between and the attorneys. Community

No instances of the community dispensing compensatory power were detected in this study. However, with the exception of George Allen, other community advocates who were deeply involved in desegregation issues had no rewards to offer and were not viable sources to receive rewards from the School Board. George Allen presents the only instance of the School Board dispensing compensatory power to a member of the community.

Based on the archival data, George Allen defended the School System in the Washington and Citizens Concerned About Our Children lawsuits that were filed against the School Board (Citizens Concerned About Our Children vs. Broward County, 1995a, 1995b; Washington, et al., vs. Broward County, 1994a). Allen stated that during his role as the attorney in the 1987 Consent Decree, he found no fact or evidence to support CCC's allegations that the School Board of Broward County discriminated against black children and staff.

CCC claimed that the School Board violated the 1987 Consent Decree, which Allen was supposedly monitoring, but on which he never challenged the School Board. The allegations raised by $\mathrm{CCC}$ against the School Board claimed unfairness and inequality in the busing of black children. The allegations of inequities in facilities, course offerings and extracurricular activities were supported and based on the findings in the 1995 report from the Desegregation Task Force (School Board of Broward County, 
1995). This report found that there were massive inequities in the School System between blacks and whites that covered seven different areas (student assignment, achievement, magnet programs, faculty and staff, facilities, transportation, and extracurricular activities). These issues of inequity should have been addressed by Allen under the 1987 Consent Decree, but were not.

Allen, in his Court deposition, (Washington, et al., vs. Broward County, 1994a) indicated that he dismissed complaints made to him by members of the black community. In a March 26, 1995 Miami Herald article (Ishoy), Allen was quoted as saying he never intended to represent the concerns of all black parents, and that he represented his own interests in the 1987 Consent Decree. He also made a similar statement during his interview. In a May 5th Broward Times article, Clayborne wrote that Allen could have gone back to Court at anytime to object to the School Board's violation of the Consent Decree because of the disproportionate busing of black children, the starbursting of black children and other inequities, but he choose not to. The article accused Allen of using the Consent Decree as a hammer over the School Board's head and allowing the School Board to hide behind it to do as they pleased against black children (Clayborne, 1995a). Allen admitted in his 1997 affidavit (Citizens Concerned About Our Children vs. Broward County, 1995b) that he approved the practice of starbursting and the "One Child Rule." Both practices were considered abhorrent by the community and were protested. The Judge stated in the April 1995 Court transcript, (Washington, et al., vs. Broward County, 1995b) that he assumed black parents and students had no complaints regarding desegregation, because he never heard anything from Attorney Allen. School Board Attorney Rogow did, however, acknowledge that there was some dissatisfaction in 
the black community, and that black parents had voiced complaints at School Board meetings. Two months prior to this hearing, Allen went to Court with School Board Attorney Marko to request $\$ 4,000$ in attorney fees, he gave the Judge the impression that "all was well"; there were no problems with the desegregation Order and he had no concerns (Smith vs. McFatter, 1995). Three months later in May 1995, under protest from the community, Allen resigned as the attorney responsible for the 1987 Consent Decree (Banker, 1995f; Marks, 1995c; Work 1995).

Allen indicated in his 1994 deposition, (Washington, et al., vs. Broward County, 1994a) that he received $\$ 200$ an hour for advising and collaborating with the School System. He also stated that he did not conduct any independent evaluations of the School Board's compliance with the 1987 Consent Decree. He relied on the information provided to him by the School Board, and made decisions based on that, while rejecting information provided to him by the community.

In the February 1995 Court transcript, (Smith vs. McFatter, 1995) School Board Attorney Marko boasted to the Judge about the cooperative relationship he and Allen had. He stated that Allen met with the School System and with staff and that that they mutually "agreed to do this or that."

Allen in his deposition, (Washington, et al., vs. Broward County, 1994a) disclosed that he was hired by private companies to lobby the School Board on their behalf. The most lucrative deal was a $\$ 40$ million contract for which he lobbied the School Board on behalf of HIP insurance. 
Wartenberg: Coercive Force

Wartenberg says that a person exercises coercive force - power over another person - when the following conditions are present:

1. $A$ has the ability to affect $B$ in a significant way.

2. $A$ threatens to do so unless $B$ acts in a certain way.

3. $B$ accedes to $A$ 's threat and alters his course of action.

Table 14 illustrates that coercive force was cited as being the power technique used the least by School Board officials; while it was identified as the primary power technique used by the community to influence desegregation policies and decisions. By contrast, data sources indicate that coercive force was used more frequently by School Board officials than by community activists. Dandy, Marko and Allen were mentioned as the major persons to use coercive force to influence and control desegregation policies and practices. (See Appendix D, who governed?)

School Board Officials. Dandy, in his role as a School Board official, was described by interviewees as being an obstructionist, whose role was frequently "keeping a lid" on things for the School Board, and for creating fear in people. Data sources also accused Dandy of running roughshod over people at Bi-Racial Committee meetings (Clayborne, 1991). (See Appendix D, who governed?)

Allen was said to enforce the 1987 Consent Decree. The perception of the data sources was that all School Board officials deferred to him for fear of being taken back to Court. Marko was said to threaten School Board members with being personally sued if they did not follow his recommendations regarding how to vote on desegregation issues. A newspaper article also stated that Marko yelled and screamed at CCC member 
Ernestine Price and threatened to end the meeting if she did not "shut up" (Citizens Concerned About Our Children, 1999). (See Appendix D, who governed?)

The Superintendent, based on data sources, threatened to cancel the School Board's advertising with the Broward Times for its stance on ending starbursting ("School District Chief Goes After," 1995). A Broward Times article accused School Board staff of calling people in the community and writing speeches for them to present against CCC at public meetings (Citizens Concerned About Our Children, 1995a). It also charged School Board staff with trying to break up the coalition CCC formed with other advocates: making it difficult for $\mathrm{CCC}$ members to speak at boundary hearings: and discouraging community people from speaking.

Attorney Fertig in the depositions for Allen and Dandy indicated that the school harassed some parents after they spoke at a School Board boundary hearing (Washington, et al., vs. Broward County, 1994a, 1994c). A Broward Times article (Citizens Concerned About Our Children, 2000a) written by CCC members stated that many School Board employees supported CCC, but had to work behind the scenes because of fear of retaliation by the School System. It stated that two persons known to the School System as supporters of $\mathrm{CCC}$ were harassed and denied promotions, even though they were the most highly-qualified applicants. It stated that one of those persons had to seek legal intervention three times. (See Appendix C, coercive force for more specific statements).

Community. The community's use of coercive force as a power technique seemed to center around its aggressive use of the media - both print and electronic. $\mathrm{CCC}$ members and the Broward Times newspaper launched a public attack against Attorney 
Allen, School Board Attorney Marko, the Superintendent and School Board members. (See Appendix C, coercive force for specific statements).

Community activists threatened to oppose the penny sales tax sponsored by the School Board if the Board did not accede to its demands to end starbursting and accept the recommendations from the Desegregation Task Force. Community activists also threatened to boycott the schools. They made good on their promises to file a complaint with the United States Department of Civil Rights, to file a lawsuit against the School Board, and to oppose the penny sales tax. The community activists did not boycott the schools.

Question \#4: How were decisions made regarding school desegregation? Who was consulted? Who was involved in desegregation decisions? The latter two questions will be answered first.

Table 15 shows that there were four primary persons in the School System who were consulted and collaborated with regarding desegregation decisions (Dandy, Marko, Sterling, and Stepanchek). All of the participants interviewed indicated that Dandy was consulted and was very involved in school desegregation decisions. Half the participants mentioned Marko and Sterling, and only two mentioned Stepanchek and the Boundary Committee. Within the community, seven out of 10 persons interviewed mentioned George Allen as being regularly consulted regarding desegregation decisions.

Based on the depositions of three different people, the community had limited input into the desegregation issues of boundaries, where children would attend school, which children would be bused and where schools would be built. Community input 
Table 15

Research Question \#4: How were Decisions made Regarding School Desegregation? Who was Consulted? Who was Involved in Desegregation Decisions?

Frequency

Principal Players

Participant

interviews
Archival data

School Board officials $(n=6)$

William Dandy

11

Ed Marko

5

1

Neil Sterling

5

Lee Stepanchek

2

Boundary Committee

2

All superintendents and area superintendents

Community members $(n=1)$

George Allen

Note. Frequency of responses is based on interviews with 11 participants and 10 sources of archival data.

came in the form of school advisory committees making recommendations to area superintendents and at School Board boundary hearings (Washington, et al., vs. Broward County, 1994b, 1994c, 1994d). How desegregation decisions were made is illustrated in Figure 3.

Only the School Board could create policy; however, the Superintendent made policy recommendations to the School Board regarding desegregation. It appears that the School Board generally accepted the policy recommendations made by the 


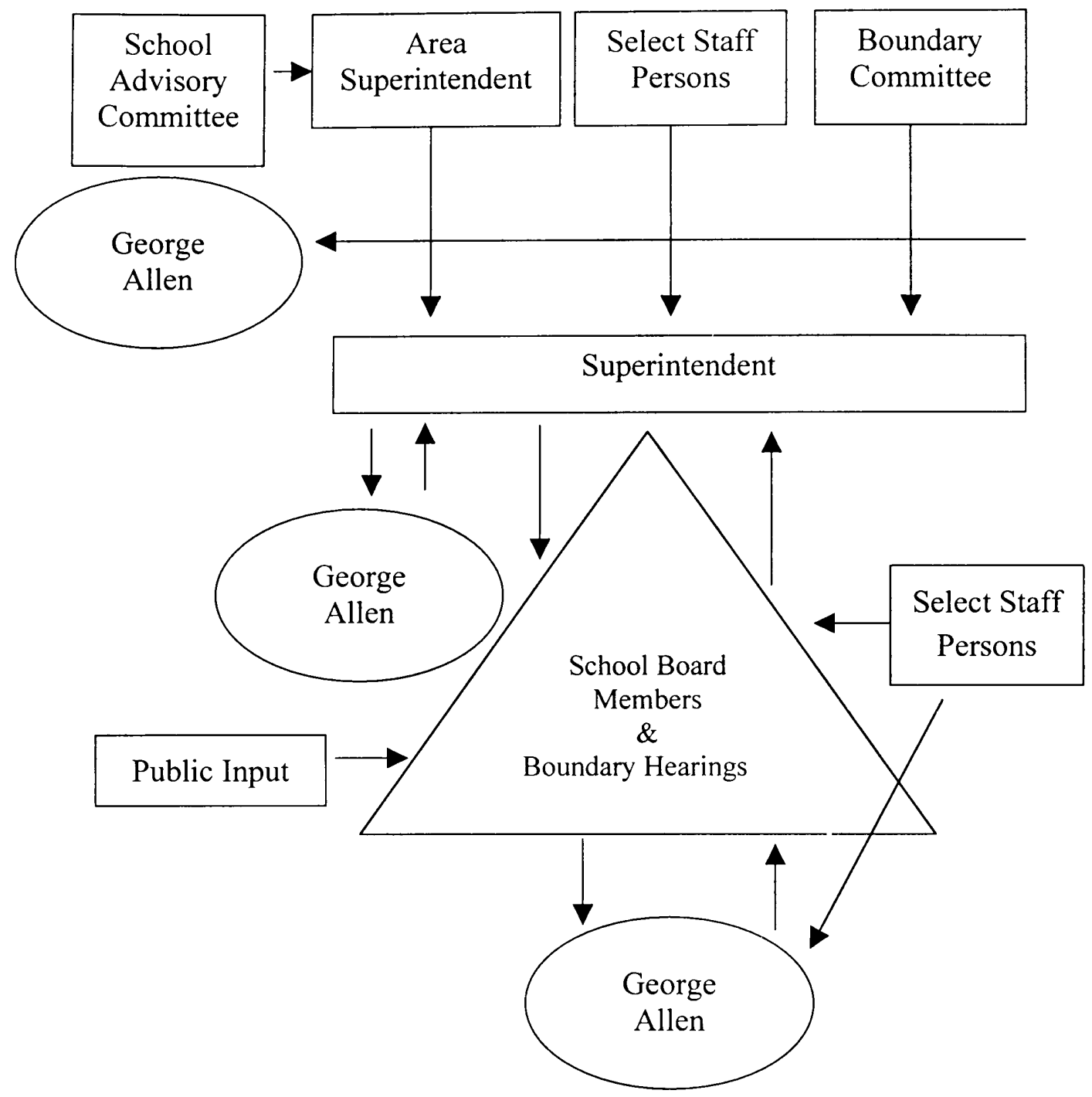

Figure 3. Question \#4: How were decisions made regarding school desegregation? Who was consulted? Who was involved in desegregation decisions?

Superintendent, and that the staff persons listed in Table 15 usually directed the superintendent's decisions and actions (Washington, et al., vs. Broward County, 1994b, $1994 c, 1994 d)$.

Once policy was approved by the School Board, staff created procedures and practices to enforce them. Based on information reported in the depositions, it appears 
that the School Board had a process to determine some school desegregation issues, such as boundaries, even though other desegregation issues, such as the closing and building of new schools and issues of equity regarding facilities and curriculum, were not as clearcut (Washington, et al., vs. Broward County, 1994b, 1994c, 1994d).

One data source indicated that when he was an area superintendent, all the area superintendents would meet to discuss boundaries and decide what they would recommend to the Superintendent. He further explained that there was a Boundary Committee that consisted of about eight or nine School Board officials. This committee would analyze the boundaries for the entire School System and make recommendations directly to the Superintendent. They also reviewed the recommendations from the School Advisory Committees and decided which ones they would include in their recommendations to the Superintendent (Washington, et al., vs. Broward County, 1994c). (See Figure 3).

This indicates that even though parents appeared to have had an opportunity to participate in determining which schools their children would attend or if their children would be bused, their input or recommendations could be discarded and never reach the ears of the superintendent or School Board members unless they attended a public boundary hearing.

At boundary hearings, School Board members rarely went against the recommendations from the Superintendent. A data source stated in his deposition that staff became upset when School Board members voted in favor of boundary recommendations suggested by the public rather than those that were recommended by them. That occurred once. After staff met with School Board members, the Board 
reversed their vote at the next meeting. A data source indicated that staff also advised School Board members during School Board meetings regarding boundaries and other desegregation issues. (Washington, et al., vs. Broward County, 1994c). (See Appendix C, power over opinions).

Several data sources reported that recommendations for boundaries and sites for new schools were presented to Allen for his approval before being presented to the School Board and that Allen was consulted on a regular basis (Washington, et al., vs. School Board, 1994b, 1994c, 1994d).

Another data source indicated that Attorney Allen's concerns were taken very seriously, but he did not have veto power (Washington, et al., vs. Broward County, 1994d).

A data source indicated that she wrote policies regarding desegregation for the School Board, which were presented to the School Board for approval (Washington, et al., vs. Broward County, 1994d). This suggests that School Board staff conceived and wrote many of the policies that were ratified by School Board members.

During their interviews, several people suggested that Dandy controlled desegregation in Broward County schools. It was stated that Dandy helped convert desegregation Court Orders into School Board policies. He was perceived as the point person on desegregation issues in the School System and held the most highly regarded opinion. No desegregation issue was approved or changed without Dandy's okay. (See Appendix D, who governed?).

It was also stated that Dandy held a meeting at his house with black community leaders to strategize the 1987 Consent Decree and that he participated in all the meetings 
between the attorneys regarding the 1987 Consent Decree. Others stated that Dandy "kept a lid" on things for the School Board and that he used his enforcement authority as a School Board administrator to deny black children entry into magnet programs and to prohibit white children from leaving black schools and vice versa. It was also alleged that Dandy was more powerful than any other deputy superintendent in the history of the School System. Some of the participants expressed outrage that he was black and the "number two" man in the School System and he allowed inequities in black schools to exist. Dandy and Allen were said to put themselves in positions of totally controlling desegregation. (See Appendix D, who governed?)

Several interviewees stated that they heard and/or were told consistently that George Allen had to be consulted before the School Board could make a decision regarding desegregation issues. (See Figure 3). Interview data also reveal that Marko threatened School Board members with personal lawsuits if they did not acquiesce to his recommendations. He consistently told them they could not tamper with the 1987 Consent Decree. (See Appendix D, who governed?)

Question \#5a: Were there any individuals or groups that were successful in influencing desegregation in Broward County? If so, who were they? Question \#5b: In what way did they influence desegregation or what was the impact of their involvement?

Based on the data sources, the same people who were consulted about and involved in desegregation decisions, as reported in research question four, were the same people who were successful in influencing desegregation in Broward County (Dandy, Marko, Sterling, Stepanchek, de la Fueilliez and Allen). The exceptions were Chris and Mary Fertig, Ernestine Price, Art Kennedy, and Janice Boursiquot from the community. 
Dandy was mentioned by all of the persons interviewed as influencing desegregation decisions in Broward County. Marko was mentioned by six of the interviewees and Sterling by five. Within the community, Allen was mentioned by seven participants as influencing desegregation in Broward County, Chris and Mary Fertig and Ernestine Price by three.

Table 16 illustrates the individuals who were successful in influencing desegregation in Broward County. Descriptions of the top nine people are presented below.

1. William Dandy was an area and deputy superintendent. He was responsible for or involved with desegregation for most of his career in the School System, which spanned about four decades. As an area superintendent, he was responsible for overseeing a cluster of schools in a particular geographic area. He served on the School Board's Boundary Committee and made boundary recommendations directly to the Superintendent, to Allen and to School Board members. He was also the coordinator of the Bi-Racial Committee that was responsible for monitoring the 1987 desegregation agreement. Dandy was said to have tremendous power, influence and control over the drawing of boundaries, and the busing of children. Data sources reported that he created the practice of starbursting black children, and the administrative rule called the "Adverse Impact Rule." He was also very instrumental in the creation of magnet programs that kept black children from leaving predominately white schools and vice versa. Data sources stated that he used the 1987 Consent Decree to empower himself to hire more black professionals, thereby, building a stronger power base for himself. 
Table 16

Research Question \#5a: Were there any Individuals or Groups that were Successful in Influencing Desegregation in Broward County? If So, Who were they?

\begin{tabular}{llc}
\hline & \multicolumn{2}{c}{ Frequency } \\
\cline { 2 - 3 } Individuals or groups & $\begin{array}{c}\text { Participant } \\
\text { interviews }\end{array}$ & $\begin{array}{c}\text { Archival } \\
\text { data }\end{array}$ \\
\hline School Board officials $(n=6)$ & 11 & 1 \\
William Dandy & 6 & 2 \\
Ed Marko & 5 & 1 \\
All superintendents (but particularly) Morgan & 5 & 1 \\
Neil Sterling & 2 & \\
Lee Stepanchek & 1 & \\
Ray de la Feuilliez & & \\
Community members $(n=6)$ & 3 & \\
George Allen & 3 & \\
Chris Fertig & 3 & \\
Mary Fertig & 3 & \\
Ernestine Price & 3 & \\
Art Kennedy & 3 & \\
Janice Boursiquot & 3 & \\
\hline
\end{tabular}

Note. Frequency of responses is based on interviews with 11 participants and 10 sources of archival data.

2. Ed Marko was the attorney for the School Board when George Allen filed his lawsuit in 1970. He remains the School Board's attorney and gives legal 
interpretations on desegregation issues. School Board members usually voted on desegregation issues based on Marko's legal advice and interpretation of desegregation court orders.

3. Neil Sterling was a School Board member who was said to be responsible for negotiating the 1987 desegregation settlement.

4. Lee Stepanchek held several positions that dealt with desegregation issues in the School System since the mid 1980s. She was a demographer, a site selector, and assigned students to schools. She wrote School Board desegregation polices that were accepted and approved by the School Board. She was also responsible for selecting where new schools would be built, as well as having had input into the closing of schools and which children would be bused. She served on the School Board's Boundary Committee.

5. Ray de la Feuilliez was Deputy Superintendent over facilities. During his lengthy career with the School Board, he held several positions that dealt with desegregation issues: selecting the sites for new schools, prioritizing the renovation and the rebuilding of older schools, recommending the closing of schools and designing yearly boundaries which helped to determine who would be bused. He served on the School Board's Boundary Committee.

6. George Allen was a private attorney who filed, two successful desegregation lawsuits against the School Board. He had a good relationship with School Board members and staff, and consulted and advised them on desegregation issues. He approved the practice of starbursting and the "One Child Rule." He also defended the School Board's desegregation policies and practices. He approved the School Board's 
annual boundary decisions and its compliance with the 1987 desegregation Consent Decree.

7. Attorney Chris Fertig filed several desegregation lawsuits against the Broward County School System over the past decade regarding school attendance boundaries, busing and equity issues. He is the attorney of record for the Citizens Concerned About Our Children (CCC) and the Washington cases. He was successful in both cases. The Washington case caused an end to starbursting and the prohibition against black children attending magnet programs. The CCC lawsuit forced the School Board to make schools, programs, courses and resources in predominately black schools equal to those in predominately white schools.

8. Mary Fertig is the wife of Attorney Chris Fertig and an education advocate. She was chairperson of the Student Assignment Sub-Committee of the Desegregation Task Force as well as a friend and consultant to CCC. She assisted her husband with the above lawsuits.

9. Ernestine Price is a parent and education activist for more than 25 years. Her activism began when the first Broward County school desegregation plan called for the closing of Blanche Ely High School, the traditional black high school in the northern part of Broward County. She and others fought for five years to get Blanche Ely reopened. Since then, she has become the major spokesperson on education issues for black people living in the northern part of Broward County (Pompano and Deerfield Beach). She is also a founding member of $\mathrm{CCC}$, and was a participant on the Desegregation Task Force. She fought against starbursting, prohibiting black children from attending magnet programs, and inequities in facilities. 
Question \#6a: Who benefited the most and who won from the School Board's desegregation policies and practices, and question \#6b: What were the benefits? These questions will be answered in conjunction with providing answers to Domhoff's three indicators of power: Who benefited and who won from the School Board's desegregation policies and practices and who governed those policies and practices?

The same or similar answers were given to Domhoff's questions of who benefited and who won? Therefore, the responses to these two questions will be combined. In many instances these questions were answered indirectly, by indication of who did not benefit or win? These types of responses were so numerous and significant that the question, "Who did not benefit?" was included in Table17. (See Appendix D).

Eight different persons or entities were identified as benefiting or winning from the School Board's policies and practices on desegregation. Builders, developers and realtors were seen as the primary beneficiaries with seven of the participants mentioning them. Five persons interviewed mentioned black children and their parents, black professionals, Dandy and white western communities.

Only two entities were identified as not benefiting and not winning from the School Board's desegregation policies and practices and they were black children and their parents and black schools and their communities. Black children and their parents were mentioned by an overwhelming majority (18 out of 21$)$ of the data sources as not benefiting from the School Board's policies and practices on desegregation. Black schools and their communities were mentioned by eight of the data sources. 
Table 17

Research Question \#6a: Who Benefited the Most and Won from the School Board's Desegregation Policies and Practices and Who Governed those Policies and Practices?

\begin{tabular}{|c|c|c|c|c|c|c|}
\hline & \multicolumn{2}{|c|}{$\begin{array}{l}\text { Who } \\
\text { benefited? }\end{array}$} & \multicolumn{2}{|c|}{$\begin{array}{l}\text { Who did not } \\
\text { benefit? }\end{array}$} & \multicolumn{2}{|c|}{$\begin{array}{c}\text { Who } \\
\text { Governed? }\end{array}$} \\
\hline & $I^{1}$ & $A^{2}$ & $I^{1}$ & $\mathrm{~A}^{2}$ & $\mathrm{I}^{1}$ & $A^{2}$ \\
\hline Builders, developers, realtor & 7 & 1 & & & 5 & \\
\hline Black children/parents & 5 & & 8 & 10 & & \\
\hline Black professionals & 5 & 1 & & & & \\
\hline Dandy & 5 & & & & 10 & 3 \\
\hline White western communities & 5 & 5 & & & & \\
\hline Allen & 3 & 2 & & & 7 & 9 \\
\hline Everyone & 3 & & & & & \\
\hline School System & 3 & 2 & & & & \\
\hline Black schools/communities & & & 5 & 3 & & \\
\hline Marko & & & & & 5 & 5 \\
\hline Boundary Committee & & & & & & 3 \\
\hline Superintendents & & & & & & 3 \\
\hline Stepanchek & & & & & & 2 \\
\hline de la Feuilliez & & & & & 1 & 2 \\
\hline Sterling & & & & & 5 & 1 \\
\hline Area superintendents & & & & & 1 & 1 \\
\hline
\end{tabular}

Note. Frequency of responses is based on interviews with 11 participants and 10 sources of archival data.

$$
{ }^{1} \mathrm{I}=\text { interview }{ }^{2} \mathrm{~A}=\text { archival }
$$


Dandy was identified as the person who had the most influence over the governance of School Board desegregation policies and practices, followed by Allen, Marko, Sterling and builders. (See Table 13).

Who Benefited and Who Won?

Developers and Western Communities

Data sources reported that developers were allowed to control where schools would be built by donating land for schools to the School Board. Subsequently, the School Board built schools that were located in the center of these new communities that the developers advertised as being their neighborhood schools. There was mention of the School Board "cutting deals" with developers and promising them never to bus children out of these neighborhoods. (See Appendix D, who benefited?) A 1988 article in Profit magazine ("Why Coral Springs?", 1988) reported that when the School Board proposed to bus children out of Coral Springs to eastern schools, parents rebelled, collected signatures and flew to Washington, D.C. to protest before the United States Supreme Court. The result was that Coral Springs children were not bused, and Coral Springs received a brand new high school, which was the largest high school in Broward County at that time. A Herald newspaper article ("Schools and Segregation," 1991) stated that "rarely are the kids from the more affluent areas bused into eastern schools." However, students were bused from eastern communities to these western schools.

Dandy

Dandy's role in governing School Board polices and practices seemed to have benefited him. He was said to have played a dual role as point person in the School System on desegregation as well as being an obstructionist in regard to community 
concerns. Several data sources said that he (Dandy) was the point person in the School System for desegregation and that desegregation decisions were made based on what he wanted. He was the second highest official in the School System, and was more powerful than any other deputy superintendent had ever been, yet he allowed inequities to exist in black schools. Dandy was said to exude power and was close to certain School Board members. He was also said to have "kept a lid" on things for the School Board. Dandy was said to be empowered with the ability to hand out jobs, which gave him power and influence. Allen and Dandy were reported to be the architects of desegregation in Broward County and to have put themselves in position of totally controlling desegregation. (See Appendix D, who benefited?) Black Children and Professionals

According to one person interviewed, black children received a better education as a result of desegregation. It was stated that more black children graduated from high school and went to college. Several other data sources indicated that the myth of white children being superior to black children was debunked. (See Appendix D, who benefited?) Data sources also reported that more black teachers and administrators were hired as a result of the 1987 Consent Decree.

Allen

As reported in his deposition, Allen said he was paid $\$ 200$ an hour for being a consultant to the School Board (Washington, et al., vs. Broward County, 1994b). He was also hired by a developer to lobby the School Board on its behalf, and by HIP insurance to lobby the School Board for a $\$ 40$ million contract. In a Court transcript, (Smith vs. 
McFatter, 1995) he and Marko went before Judge Ryscamp to request $\$ 4,000$ in attorney's fees for Allen providing consulting services to the School Board.

School System

Marko, as School Board attorney, stated in his deposition that the School Board received in excess of $\$ 5$ million in federal funds for magnet programs. He also indicated that one of the advantages of the 1987 Decree was that the School Board was not required to report to the Court (Washington, et al., vs. Broward County, 1994b).

Who did not Benefit?

Various data sources indicated that desegregation fell primarily on the backs of black children because they were starbursted, bused to predominately black schools, and were prohibited from attending magnet programs. They did not have current textbooks, and could not check out library books. They were tracked and grouped into low-level programs and/or classes, and were denied certain extra-curricular activities and academic clubs. (See Appendix D, who did not benefit?)

\section{Who Governed?}

Five people or entities were identified as primarily governing the School Board's desegregation policies and practices (Dandy, Allen, Marko, developers and school board officials).

Dandy

Dandy was said to hand out jobs, which gave him power and influence. Data sources indicated that Dandy was the School Board's point person on school desegregation; that he initiated starbursting and was responsible for poor children crossing dangerous streets to attend white schools. One data source remarked that he 
(Dandy) wanted a black child in every white school, but didn't care what happened to them in those white schools. It was stated that nothing having to do with desegregation was approved or changed without Dandy's okay, his opinion was the most highlyregarded and was the social conscience of the School System. Decisions were made based on what Dandy wanted, including many of the boundary decisions. (See Appendix D, who governed?

It was stated that even though Dandy was the "number-two" man in the School System and was more powerful than any other deputy superintendent ever was, he allowed inequities in black schools to exist. Other data sources stated that Dandy played a dual role as point person in the School System on school desegregation as well as being an obstructionist in his relationship with the community. Dandy's role was to "keep a lid" on situations for the School Board. He held an important meeting at his house to strategize the 1987 Consent Decree. (See Appendix D, who governed?) Allen

Allen stated that he met with Neil Sterling (Chairperson of the School Board), and School Board Attorney Marko to craft the 1987 Consent Decree. Leary stated in his interview that Sterling and Allen worked with political figures in the community (regarding the 1987 Consent Decree). They focused on making black contractors beneficiaries of the 1987 Bond Issue ( $\$ 320$ million) and on the hiring of more black teachers and some Hispanics. Allen stated that he approved the practice of starbursting under the 1970 lawsuit as well as the "Adverse Impact Rule." Allen was known to have had a large number of important contacts in the black community. (See Appendix D, who governed?) 
Court transcripts reveal that Marko said to Judge Ryscamp that he and Allen wrote the Consent Decree in a way that would protect federal funds and keep such funds coming into the school district. Marko said to Judge Ryscamp that Allen, as representative for the Plaintiff, had been extremely cooperative with the School Board; that Allen had met in consultation with School Board staff and they mutually "agreed to do this or not do that." Judge Ryscamp indicated that Attorney Allen was the spokesperson for the black community on school desegregation. The judge questioned whether the community had any complaints or concerns about school desegregation, because Allen had not brought any concerns to his attention (Washington, et al., vs. Broward County, 1995b; Smith vs. McFatter, 1995).

Another data source declared that Allen and Dandy were the architects of desegregation in the Broward County School System and that Allen and Dandy put themselves in a position to totally control desegregation. They were both premiere leaders in the black community. One data source said that Allen was "the man." "They told me he (Allen) had to approve everything." Several other data sources also stated that Allen had to approve all desegregation decisions. Allen stated that when he provided advice to the School Board, he relied on information furnished to him by School Board staff. One data source stated that Allen's concerns were taken very seriously, but he did not have veto power. (See Appendix D, who governed?) Marko

One data source stated that Marko is the longest living, sole person on desegregation in the School System and its lead attorney. Marko's role is to provide legal advice to School Board members and staff regarding a number of legal issues - including 
desegregation. Several data sources stated that Marko frightened School Board members into voting the way he wanted them to on desegregation issues. He threatened them with being held in contempt if they violated the 1987 Consent Decree. Attorney Fertig testified before Judge Ryscamp (Smith vs. McFatter, 1995) that School Board members refused to respond to the community because they were told repeatedly (by Marko) that to do so would violate the 1987 Consent Decree. He told them they could be personally sued if they voted against the "One Child or Adverse Impact Rule." Other data sources said that Marko was insistent that they had no alternative but to bus black children, even to black schools outside their neighborhoods. (See Appendix D, who governed?) Developers

Several individuals stated that developers were allowed to control where new schools would be built, and that they donated land to the School Board on which they subsequently built schools that were predominately white. The interviewees also stated that the developers, builders, and realtors advertised these new western schools as being neighborhood schools and promised the buyers that their children would never be bused to integrate the schools. (See Appendix D, who governed?)

\section{School Board Officials}

School Board Officials include members of the Boundary Committee, superintendents, Stepanchek, de la Feuilliez, and Sterling. Neil Sterling, who was Chairperson of the School Board in 1986-87, said he took the initiative to mediate a settlement agreement between the School Board and Allen. He felt that it was his responsibility as an elected official to get involved in issues rather than to duck them. He 
and other data sources credit him with negotiating a settlement agreement with Attorney Allen. (See Appendix D, who governed?)

Particular School Board staff seemed to have played a major role in the governance of desegregation policies. These staff persons reportedly fed misinformation to School Board members. Another data source stated that School Board members were too easily influenced by staff (Dandy, Stepanchek, Sasse, Morgan, Whitman). Dandy mentioned that staff became upset if School Board members voted in favor of boundary recommendations that came from the public, but not recommended by staff. On one occasion, School Board members voted in favor of Harbordale parents, but reversed their decision at the next meeting after being influenced by Dandy and other staff persons. (See Appendix D, who governed?)

It was stated in depositions that the Boundary Committee, which was comprised of eight or nine School Board officials (including Dandy, de la Feuilliez, Stepanchek, and Whitman), decided the boundaries for the School Board, and where new schools would be built (Washington et al., vs. Broward County, 1994c, 1994d). Stepanchek indicated that she advised the School Board regarding boundaries and the selection of new sites for schools. She also wrote policies for the School Board regarding desegregation. She indicated that de la Feuilliez also reviewed the policies.

A February Broward Times article (Kiffin, 1995e) quoted a member of the Desegregation Task Force who criticized the Superintendent, by saying what he recommended to the School Board, regarding starbursting, was a weakened version of what the Task Force had recommended. Another Broward Times article (1999) written by $\mathrm{CCC}$ was entitled "School Board reneges on equity plan and insults black 
community." The article indicated that the settlement proposal negotiated between CCC and the School Board was not what they agreed to in their meeting with the Superintendent. They accused him of taking out all the language ensuring equity and parity.

Question \#7: What was the response from the overall African American community to the School Board's desegregation policies, plans, and practices?

Table 18 tells us that the African American community was not pleased with the School Board's desegregation policies, plans, or practices. Eighteen out of 21 participants interviewed indicated that black people in Broward County, Florida were opposed to the School Board's desegregation policies and practices.

Data sources indicated that the black community was conflicted about desegregation at first. They thought desegregation would give their children a better education; however, they ceased to support desegregation when they realized that they bore the brunt of desegregation, and that their children were not benefiting or learning (Marks, 1991d; Black Parents, 1995; Brown, 1995). Another data source indicated that the black community always objected to the School Board's unfair desegregation policies and practices, and that the black community always fought and criticized the School Board's desegregation policies and practices.

\section{Summary}

Chapter IV presents the findings related to the nine research questions regarding what forms of power were used and how School Board officials and community activists exercised power. Additionally, the questions of who benefited and who won from the School Board's desegregation policies and who governed those policies and practices 
Table 18

Research question \#7: What was the Response from the Overall African American Community to the School Board's Desegregation Policies, Plans and Practices?

\begin{tabular}{lcc}
\hline & \multicolumn{2}{c}{ Frequency } \\
\cline { 2 - 3 } Response & $\begin{array}{c}\text { Participant } \\
\text { interviews }\end{array}$ & $\begin{array}{c}\text { Archival } \\
\text { Data }\end{array}$ \\
\hline Supported & 3 & \\
Opposed & 8 & 10 \\
\hline
\end{tabular}

Note. Frequency of responses is based on interviews with 11 participants and 10 sources of archival data

were examined. The following lists the responses to the research questions and to Domhoff's indicators of power: who benefited, who won, and who governed?

1. Issues cited as being the major factors that made desegregation an important power issue in Broward County were: related to the busing of students; inequity in facilities, resources, courses, and education; the segregation and resegregation of schools. (See Table 12 and Appendix B).

2. The principal power players who governed the School Board's desegregation policies and practices were William Dandy, School Board official; Neil Sterling, School Board Chairperson; Ed Marko, School Board attorney; and George Allen, attorney for the plaintiff in two desegregation lawsuits against the School Board. (See Table 13).

3. The primary power techniques used by officials in the Broward County School System and by community activists to influence desegregation decisions were: (a) influencing the opinions of School Board members, personnel and the public; (b) compensation to School Board staff and to the plaintiff's attorney; and (c) using coercive 
force against School Board employees and officials and against community activists.

The power techniques used by community activists were coercive force and power over opinions. (See Table 14 and Appendix C).

4. The community had very little input into and influence over desegregation decisions. A select group of eight or nine different School Board officials who constituted the Boundary Committee controlled desegregation decisions. This committee recommended to the Superintendent where children would attend school, what children would or would not be bused, where to build new schools, and what schools would be closed. (See Figure 3 and Appendix D, who governed?)

5. Parents and the community had two opportunities to influence desegregation decisions. Each school had an advisory committee that met with the parents and staff in that school and made boundary recommendations to the area superintendent. However, the area superintendent decided which of those recommendations would be included in the recommendations to the Superintendent who then made recommendations to the School Board. (See Figure 3 and Appendix D, who governed?)

6. Parents and the community had input again at boundary hearings, when they could make recommendations or oppose desegregation policies and practices directly to School Board members. It was noted that recommendations from the community or the public were rarely accepted by the School Board if the staff did not support them. (See Figure 3 and Appendix D, who governed?) School Board officials consistently consulted with Attorney Allen and sought his approval on desegregation decisions. 
7. The persons cited as having the greatest influence on desegregation decisions in Broward County were, in descending order: Dandy, a black School Board administrator, who was considered the architect and point person on school desegregation in Broward County for about three decades. Marko, the School Board attorney for more than three decades; and Neil Sterling, who was Chairperson of the School Board in 1987 and took the initiative to negotiate the 1987 desegregation settlement agreement. (See Table 16).

8. From the community, George Allen, Chris and Mary Fertig and Ernestine Price had substantial influence. Mr. Allen successfully filed two desegregation lawsuits against the School Board, which made him the most influential and powerful person regarding desegregation issues in Broward County, Florida for 25 years. (See Table 16).

9. The Fertigs filed several desegregation lawsuits against the School Board. The most notable cases are the Washington and Citizens Concerned About Our Children lawsuits. The Washington case ended starbursting and stopped the School Board from using race as the criterion for assigning children to schools and programs. The Citizens Concerned About Our Children lawsuit forced the School Board to allocate more money and resources to predominately black and eastern schools.

10. Ernestine Price is an African American education activist for more than 25 years. She participated in the effort to get Blanche Ely High School reopened and was a co-founder of CCC. She was very influential in getting the 1995 penny sales tax defeated.

11. Eight different persons or entities were reported to be the major beneficiaries from the School Board's policies and practices on desegregation: builders, 
developers, realtors; black children and their parents; black professionals; Dandy; white western communities; Allen; everyone; and the School System (See Table 17 and Appendix D).

12. Builders, developers, and realtors were seen as the primary beneficiaries from desegregation policies and practices. Developers and western communities benefited because schools that they claimed as their own neighborhood schools were built in those western developments. There was no busing of children outside of these communities. As families fled from eastern communities to western communities to avoid busing, builders and developers reaped increased profits from building and selling more and more homes. (See Appendix D, who benefited?).

13. Black children benefited from the School Board's desegregation policies because they gained more access to academic programs and, in the process, they negated the myth of black children being inferior to white children.

14. Black teachers and administrators benefited from the School Board's desegregation policies because more were hired as a result of the 1987 Consent Decree. Black contractors received more business opportunities with the School System. (See Table 17 and Appendix D, who benefited?).

15. Dandy benefited from the School Board's desegregation policies because he gained promotions for his leadership and support in developing and enforcing the School Board's desegregation policies and practices. He controlled the favors and used the 1987 Consent Decree to hire more black teachers and administrators. This gave him more power and a stronger base of people loyal to him. (See Appendix D, who benefited?). 
16. Allen benefited from the School Board's desegregation policies and practices because he was paid as a consultant for providing consulting services to the School Board on desegregation issues. Because of his amicable relationship with the School Board, he was hired by private companies to lobby the School Board for them. (See Appendix D, who benefited?).

17. The School System benefited from desegregation policies and practices because it received in excess of $\$ 5$ million in federal funds for magnet programs and because it was able to implement the 1987 settlement agreement without being under the supervision of the Court. (See Appendix D, who benefited?).

18. Only two entities were identified as not benefiting and not winning from the School Board's desegregation policies and practices: black children and their parents and black schools and their communities. They did not benefit because black children were disproportionately bused and were the only children starbursted. They were bused to predominately black schools and prohibited from attending magnet programs. Black parents were less able to attend PTA and advisory meetings or school conferences because many of them did not have transportation to get to the distant schools to which their children were bused. Black children were limited in their ability to participate in extra-curricular activities because of transportation. (See Table 17 and Appendix D, who did not benefit?).

19. Four people or entities were suggested as primarily governing the School Board's desegregation policies and practices. Dandy was identified as the person who had the most influence over the governance of desegregation policies and practices, 
followed by Allen, Marko and developers (See Table 16 and Appendix D, who governed?).

20. Dandy was the School Board's point person on school desegregation and was responsible for creating the practice of starbursting. He was instrumental in formulating the "One Child or Adverse Impact Rule." Both of these practices were criticized by the community for being unfair, unjust, discriminatory, and disruptive to children and families. Nothing regarding desegregation was approved or changed without Dandy's okay. Desegregation decisions were made based on what pleased Dandy. (See Appendix D, who governed?).

21. As attorney for the Plaintiff in the 1987 lawsuit, Mr. Allen was supposed to monitor the School Board's compliance with the 1987 Consent Decree. However, he failed to take the School Board back to Court, and thus allowed: the School Board to violate the settlement agreement by disproportionately busing black children; allowed predominately white schools to be built out west, which effectively re-segregated Broward County schools; and allowed the busing of black children to black schools. Allen also approved the starbursting of black children and the "One Child or Adverse Impact Rule," which the community vehemently opposed. (See Appendix D, who governed?).

22. School Board members were easily influenced by staff who provided misinformation. School Board staff responded negatively when School Board members voted in favor of boundary recommendations that came from the public, rather than from them. Whenever this occurred, staff would seek to undermine the community's influence on School Board members. (See Appendix D, who governed?). 
23. The School Board attorney would misrepresent information to the media regarding desegregation issues. The superintendent reneged on agreements he had previously made with community activists and their attorneys.

24. George Allen's advice to the School System was based solely on the data and information provided to him by School Board staff. He conducted no independent analyses of information or investigations and dismissed information provided to him by the community. He stated that he never intended to represent the interests of the community when he filed his desegregation lawsuits; that he represented solely his own interests. (See Appendix D, who governed?).

25. Developers, builders, and realtors were said to dictate to the School Board where they would build new schools - in predominately white, western communities. Developers also donated land to the School Board on which they built the schools that they advertised as being neighborhood schools. They promised the buyers that their children would never be bused in order to integrate the schools. (See Appendix D, who governed?) 


\section{CHAPTER V \\ DISCUSSION}

Chapter V summarizes the previous four chapters; presents conclusions gleaned from the research and offers some practical recommendations for using the knowledge gained from this study and recommendations that will further advance the research on desegregation.

\section{Summary}

The landmark decision of Brown vs. Board of Education has been credited with advancing the cause of civil rights more than any other effort in this country; it opened the doors to an assortment of other civil liberties for blacks and other minorities. Because of the social science arguments presented in Brown vs. Board of Education, school systems in this country became the incubators for race relations. From the onset of the desegregation discussion, there were two basic points of view on solutions: one was for black people to gain equal access to public facilities; and the other was for social integration between blacks and whites. The concept of integration prevailed in the Brown vs. Board of Education case.

This same dichotomy existed in Broward County, Florida. Initially, the community was supportive of the School Board's desegregation plan. In the mid 1980s, the black community began to object to the School Board's desegregation plan and criticized it for not providing black children with a quality education or equity and equal access to facilities and programs. A grassroots group called Citizens Concerned About Our Children (CCC) finally filed a lawsuit in 1995. They claimed that the School 
Board's desegregation policies and practices were discriminatory against black children (Citizens Concerned About Our Children vs. Broward County, 1995a). The relationship between the black community and the School Board was very contentious over these issues (Citizens Concerned About Our Children, 1995a, 1995b, 1996, 1999).

This is a historical case study on school desegregation and power in Broward County, Florida from 1970 to 1998 . The purpose of this study is to describe, explain and analyze types and uses of power by the School Board of Broward County, Florida and community activists, in their efforts to influence and govern desegregation from 1970 to 1998.

The historical case study approach to research was used as the method for conducting this study because this method is generally used when the researcher is seeking a better understanding of relationships, and to provide answers to initially unknown questions. The historical case study method is also a common research technique used by researchers conducting studies on school desegregation.

The various data sources used in this study include 11 participant interviews and a variety of different sources of archival data. Two-hour interviews were held with the participants between September 2001 and September 2002. All the interviews were audiotaped except one, because permission was not granted. The participants included persons directly involved in school desegregation issues either as School Board officials (5) or community activists (6). The archival data sources included an affidavit, four court depositions, two court transcripts and newspaper articles from four local newspapers from 1991-2000. 
The theoretical models of Russell, Galbraith, Wartenberg and Domhoff were used to determine the different types of power techniques used by School Board officials and community activists and to answer Domhoff's three questions: who benefited and who won from the School Board's desegregation decisions and who governed those desegregation policies and practices? The data were analyzed against the nine research questions and Domhoff's three indicators of power questions.

A frequency count was performed based on how each of the data sources (interview and archival data sources) responded to the research questions and to Domhoff's three indicators of power. A single count of one (1) was given regardless of how often a participant may have addressed any of the research questions or Domhoff's indicators of power. Tables are provided for most of the responses to the research questions and to Domhoff's indicators of power.

The researcher's interest in the topic of power and school desegregation in the Broward County School System spans almost two decades. She has worked in over 30 different schools in Broward County as a School Social Worker over the past 23 years. The researcher presented a list of scenarios that stimulated her interest in the topic of school desegregation, based on her actual experience as a School Social Worker. All of the issues and examples had underpinnings in the 1987 Consent Decree and, therefore, involved School Board policies and practices on desegregation.

\section{Conclusions}

The findings in Chapter IV serve as the basis for the researcher's conclusions, which are now presented. The conclusions are presented in the framework of Domhoff's three indicators of power: who benefited, who won and who governed; and the question 
asked in the Statement of Purpose of this research regarding how power was exercised by the School Board of Broward County, Florida and by the grassroots community in their efforts to influence desegregation from 1970 to 1998 . The persons or entities that benefited and won from the School Board's policies and practices on desegregation are the same ones that governed the desegregation policy decisions.

Who Benefited and Who Won?

White children and their communities, builders and developers. White, affluent communities in the western part of Broward County; the children and their parents; and the builders, developers and realtors were identified by 18 out of 21 data sources as being the primary beneficiaries of school desegregation policies and practices in Broward County (See Table 17). They benefited because of the School Board's desegregation policies and practices of only busing children from eastern, predominantly black communities and not from the western, mostly white communities.

Information contained in the Desegregation Task Force Report (School Board of Broward County, 1995) revealed that since the 1971 desegregation Court Order, 38 new schools were built in western communities with a sum total of nine percent black students (see Table 2).

This researcher concludes that the power-structure theory was operational and can be demonstrated in Broward County, Florida. Harvey Molotch, a sociologist concluded that:

A community power structure is at bottom an aggregate of land-based interests that profit from increasingly intensive use of land. It is a set of property owners who see their futures as linked because of a common desire to increase the value of their individual parcels (Cited in Domhoff, 1983, pp. 166-167). 
The most typical way of intensifying land use is growth, and this growth usually expresses itself in a constantly rising population. A successful local elite is one that is able to attract the corporate plants and offices, the defense contracts, the federal and state agencies, or the educational and research establishments that lead to an expanded work force, and then in turn to an expansion of retail and other commercial activity, extensive land and housing development, and increased financial activity (Cited in Domhoff, 1983, pp. 166-167).

That is, in essence, what occurred with desegregation in Broward County. Because of the School Board's one-sided desegregation plan of not forcibly busing children from the new, predominantly white developments in the western parts of Broward County, white families fled west to avoid busing, where their children could attend new, high-quality neighborhood schools, with state-of-the-art equipment. Black children continued to attend dilapidated schools that were devoid of current technology and equipment in the eastern part of the County. The builders, developers and realtors reaped increased profits from building and selling more and more homes as they promoted these western communities as having their own neighborhood schools. (See Appendix D, who benefited and who governed?).

Dandy. Dandy, a black School Board administrator and prominent leader in the black community was identified as the second person or entity to benefit from the School Board's desegregation policies. Several persons interviewed stated that he was rewarded because of his leadership and support in developing and enforcing the School Board's desegregation policies and practices, and "keeping a lid" on activities in the black community. Several interviewees also stated that Dandy controlled the favors and used the 1987 Consent Decree to hire more black teachers and administrators, which gave him more power and a stronger base of people loyal to him. (See Appendix C, compensation). 
Allen. Mr. Allen successfully filed two desegregation lawsuits against the School Board, which made him the most influential and powerful person regarding desegregation issues for 25 years. It also made him one of the most prominent black leaders in Broward County, if not the State of Florida. Allen benefited from the School Board's desegregation policies and practices because he was paid $\$ 200$ an hour as a consultant for providing consultation services to the School Board on desegregation issues. Because of his amicable relationship with the School Board, he was hired by private companies to lobby the School Board for them. HIP insurance hired him to lobby the School Board for a $\$ 40$ million contract. (See Table 17 and Appendix C, compensation).

School system. The School System benefited from desegregation policies and practices because it received in excess of $\$ 5$ million in federal funds for magnet programs. It also benefited because it was able to implement the 1987 settlement agreement without being under the supervision of the Court. This allowed the School System to violate the 1987 Consent Decree by placing the burden of desegregation on black children, since it did not want to antagonize white parents who had more political influence and clout. (See Table 17 and Appendix C, compensation).

Black children, the community and professionals. Black children, parents, and professionals were named as benefiting from school desegregation policies and practices by 11 out of 21 data sources, (See Table 17). The following were described as benefits to them:

1. Black children received a better education; more of them finished high school and went to college. 
2. Black children experienced an increase in self-esteem as they realized that white children were not better than they were.

3. Black children had more accessibility to better educational resources and services.

4. The 1987 Consent Decree was responsible for more black contractors and other black businesses being hired by the School System, in addition to its increase in hiring of more black professionals.

5. Blacks in general benefited because of the general benefits implicit in implementing equal access.

Only one person interviewed stated that black children received a better education in white schools. This statement is based on an erroneous assumption, because the empirical data from Dr. Johnson's (1986) research and from the School Board's 1997 report, (Broward County Public Schools, 1998-99) do not support this premise.

In 1986, Dr. James Johnson, a research professor at Nova University, conducted a study in Broward County, Florida, in which he compared the achievement levels of black students attending their neighborhood schools against those attending desegregated schools. He concluded that black students who attended their own neighborhood schools performed better than black students bused to predominately white schools (Johnson, 1986).

A June 1999 newspaper article and internal Broward County School Board report revealed that many black students attending predominately white schools scored in the bottom quartile in reading, math and writing and most if not all the students in those 
schools who scored in the bottom quartile were black (Hirschman, 1999; Broward County Public Schools, 1998-99).

The participant who made the statement that black children perform better in white schools seems to be guilty of what Faltz and Leake (1996) spoke about. They said that any real, substantive dialogue and analysis of school desegregation had been stymied by three basic assumptions. The first assumption is that desegregation was effective without any empirical data to back up this claim. They posed two questions that should be asked: Who benefits from court-ordered desegregation and has desegregation improved the education of black students? The second assumption is that black parents are die-hard supporters of desegregation. The third is that black children can only receive a quality education in desegregated schools.

A review of the literature in Chapter II has shown, and more specifically - the black parents and community in Broward County, Florida have established, that black parents were willing to accept the burden of busing and desegregation initially, because they thought that their children would receive a better education; however, they ceased to support desegregation when they began realizing that their children did not benefit from being bused to predominately white schools. Table 18 showed that the black community in Broward County overwhelming opposed the School Board's desegregation policies and practices.

The other perceived benefits of desegregation in Broward County seem to fit into the "harm and benefits" theory. This theory, as introduced in Chapter II, advocated two points. The first point is that segregated schools harmed the education and academic achievement of black children by reinforcing negative racial stereotypes and damaging 
their self-esteem. The second point is that desegregation benefited the self-esteem, academic achievement, and long-term educational and occupational outcomes for black children while improving race relations for everyone (Armor, 1995).

In 1967, the United States Commission on Civil Rights issued a report entitled Racial Isolation in the Public Schools. This report appealed to Congress to pass legislation compelling schools to eliminate racial isolation and to establish a racial balance standard of not more than 50 percent black children in any public school (Armor, 1995). The Commission advocated that schools should be considered segregated and inferior when their composition exceeded 50 percent black children (U.S. Commission on Civil Rights, 1967).

This seems to have set the foundation for the development of the assumptions to which Faltz and Leake alluded. Many people just assumed that if black children attend school with white children, they would automatically learn. These people made those assumptions without having any data to support them or by ignoring empirical data which supported a contrary position (Faltz and Leake, 1996).

Several other people interviewed stated that society in general benefited because of integration. This seems to fit into the "contact theory" of desegregation which suggested that interracial contact, under the right conditions, can improve race relations, interracial understanding, reduce prejudice, and increase the self-esteem of black children. The implication is that school segregation promoted racial ignorance, stereotypes, intolerance, and bigotry. (Armor, 1995).

The emphasis on hiring more black teachers and administrators resembles what is commonly referred to as the "Atlanta Compromise." In 1973, the national NAACP office 
admonished the Atlanta, Georgia branch of the NAACP for adopting a school desegregation plan that provided minimally for desegregation. The plan called for the mass busing of black children in exchange for the hiring of 50 percent black administrators ("NAACP Suspends Atlanta Unit," 1973). This is essentially what occurred with the negotiation, interpretation and implementation of the 1987 desegregation settlement agreement in Broward County, Florida. The emphasis was placed on the hiring of black teachers and administrators, rather than on equalizing the burden of busing between the white and black community and creating more equity for black children.

\section{Who Did Not Benefit or Win?}

Only two entities were identified as not benefiting and not winning from the School Board's desegregation policies and practices and they were black children and their parents and black schools and their communities.

All the data sources responded in some way that black children and their parents and black schools and their communities did not benefit from the School Board's desegregation policies and practices. Several participants stated that black children were used as pawns in school desegregation in Broward County, Florida.

Black children did not benefit because, under the 1987 Consent Decree, they were disproportionately bused and were the only children starbursted. The School System appeared to use the black community as a desegregation warehouse. Starbursting was created as the School Board's desegregation plan in order to provide a critical mass of black students to predominately white schools. 
Ninety-one percent of the children bused for purposes of desegregation were black. They were even bused to predominately black schools rather than being allowed to attend their own neighborhood schools. Black parents found it very difficult to attend PTA and advisory meetings or school conferences, because they had limited transportation to far away schools to which their children were bused. Black children found it difficult to participate in extra-curricular activities because of transportation logistics.

The Broward County School System became more segregated, with 38 new schools with a combined black student population of only nine percent, being built in predominantly white, western communities, while predominately black schools were in serious disrepair. Black children were prohibited from attending magnet programs. The suspension rate of black children doubled that of white children, and the placement of black children in the emotional handicapped (retarded) program was triple that of white children (School Board of Broward County, 1995). The African American community in Broward County continues to suffer from the residual affects of past desegregation policies and practices.

Derrick Bell's viewpoint on desegregation continues to resonate in Broward County. Bell (1980) asserted that black people became the victims in school desegregation. He stated that all the progress made in desegregation depended more on the benefits to white people than the benefits to black people. He said that blacks suffered disproportionately because of the kinds of desegregation policies and practices created (School Desegregation, 1991). 
The community had very little input into and influence over desegregation decisions. A select group of eight or nine School Board officials who constituted the Boundary Committee were the primary decision-makers on desegregation issues. This committee made recommendations to the Superintendent about: where children would attend school; which children would or would not be bused; where to build new schools; and what schools would be closed (Citizens Concerned About Our Children, 1997b, 1997c; Washington, et al., vs. School Board, 1994c, 1994d). (See Figure 3).

Four people or entities primarily governed the School Board's desegregation policies and practices. Dandy was identified as the person who had the most influence over the governance of desegregation policies and practices, followed by Allen and Marko and developers (See Tables 13, 15, 16 and 17). The first three people essentially governed desegregation policies and practices in Broward County for about three decades. All of them seemed to have a vested interest in maintaining the status quo. All three were well compensated - in terms of jobs, promotions, power, and/or finances - for rebuffing and rejecting the community's input. It appears that all three people collaborated to get millions of dollars for magnet programs (from which black children were excluded) for the School System. (See Appendix D, Who governed?).

Dandy. Dandy was the School Board's point person on school desegregation and was responsible for creating the practice of starbursting and the "One Child or Adverse Impact Rule." Both of these practices were criticized by the community for being unfair, unjust, discriminatory, and disruptive to children and families. Interviewees stated that nothing regarding desegregation was approved or changed without Dandy's approval. 
Desegregation decisions were made based on what pleased Dandy. (See Appendix D, Who governed?)

Dandy influenced all desegregation decisions in Broward County for about three decades. If he had this kind of power, authority, and influence, then why did he not use it to make the system more equitable and fair to black children? Why did he allow the conditions to exist that made it necessary for the 1987 Consent Decree to be issued, or necessary for CCC to file another lawsuit in 1995 ? Why did he create the practice of starbursting with its negative concomitant ramifications and the unfair and irrational "Adverse Impact Rule?"

This research raises the issue of the value to the black community of having black people in positions of power and authority. Dandy was described numerous times as being very powerful. He was one of the most powerful administrators ever in the Broward County School System and had the respect and support of School Board members and the white power structure. He developed a large base of social and political support because of the people loyal to him when he was given the power and authority to offer favors and to hire most of the black professionals in the School System (which is the largest employer in Broward County). (See Appendix D, who governed?).

Allen. Allen was the attorney for the plaintiffs in the 1971 and 1987 lawsuits. Mr. Allen was supposed to monitor the School Board's compliance with the1987 Consent Decree. He failed to take the School Board back to court. He allowed: the School Board to violate the settlement agreement by disproportionately busing black children; predominately white schools to be built in the western part of the County (which had a segregative effect); and the busing of black children to black schools. Allen also 
approved the starbursting of black children and the "One Child or Adverse Impact Rule," which the community vehemently opposed.

Mr. Allen was paid to advise the School System on desegregation issues. He stated in his deposition that his advice to the School Board was based solely on the data and information provided to him by School Board staff. He conducted no independent analysis of information or investigations and dismissed information provided to him from the community. He stated that he never intended to represent the interests of the community when he filed his desegregation lawsuits; that he represented his own interests. (Alexander, 1995; Washington, et al., vs. Broward County, 1994a).

This research demonstrates how one person can, and did for many years, direct and control issues of major importance to massive numbers of children, families and the community. Even though Allen did not have any of his own children attending the Broward County School System, and he was not an elected official or School Board employee, he dictated, to a great degree; where children would attend school; who and who would not be bused; what schools would be closed; and where new schools would be built. He made a decision between supporting the interests of the School Board or supporting the interests of the community and the people who were affected by the lawsuit he filed. He unapologetically chose to support the interests of the School Board (Citizens Concerned About Our Children, 1995b; Washington, et al., vs. Broward County, 1994a).

Why would two of the most prominent leaders in the black community (Allen and Dandy) support the interests of the School System rather than the interests of black children, black parents and the black community? Perhaps T'Shaka explains this mystery 
when he equated the role and function of leaders in the black community to that of neocolonizers in Africa. Elitist blacks were trained as proxies to carry out the wishes and mandates of the white power structure and, in essence, control all other black people in their respective communities. He asserts that the black elite acts as a buffer between the black masses and the oppressive white power structure. "They often have contempt for their own black people" (T'Shaka, 1990, p. 290).

School Board officials. Ed Marko was School Board attorney since the 1971 desegregation lawsuit was filed. Data sources stated that he misrepresented information to the media regarding desegregation issues. The Superintendent reneged on agreements he had previously made with community activists and their attorneys. School Board officials fed misinformation to School Board members and easily influenced them. School Board officials became upset if School Board members voted in favor of boundary recommendations that came from the public and were not recommended by them. Whenever these situations occurred, School Board officials would seek to undermine the community's input or influence with School Board members (Citizens Concerned About Our Children, 1999). (See Appendix D, Who governed?)

The question of why School Board officials were not more sensitive and responsive to the concerns expressed by the black community needs to be explained. After all, desegregation was supposed to benefit black children. Could the answer be found in Pfeffer, when he stated that those wielding power in institutions are usually so blinded by their vested interests that they oppose any change, and that change almost always comes from people outside the mainstream in the organization or from outside the organization (Pfeffer, 1992). 
The intent and purpose of school desegregation was to provide more and greater educational opportunities to black children; however, in Broward County and in school districts around the United States, it appears that the solution became the problem. CCC and the community had to force change upon the School System in Broward County and were successful after a valiant and protracted fight.

\section{Power Techniques Used}

The primary power techniques used by School Board officials to influence desegregation decisions were power over opinions (propaganda), compensation and coercive force in that order. The community employed the techniques of coercive force and power over opinions. (See Table 14).

\section{Power Over Opinions}

School Board officials. They were in a better position to influence the opinions of people than the community was. The School System could influence opinions without it appearing to be propagandizing or antagonistic toward the goals of desegregation. During their normal course of doing business, by developing and presenting reports and making press statements, School Board officials would promote their point of view. Superintendent Frank Petruzielo understood the importance and power of propaganda, so he created a Public Relations Department within the School System. This subtle approach by the School System made the same power technique used by the community (power over opinions) appear hostile and combative. When School Board officials presented information, it had the appearance of being credible, objective and unbiased. When community activists presented information, it seemed biased, antagonistic and not as credible. 
School Board officials were less forthright in their answers to the interview questions than were the community people. One School Board official refused to be audiotaped, one refused to answer specific questions and several of them were evasive in their answers. There were also inconsistencies between the answers that some of them provided and the archival data.

There was uniformity between the responses provided by School Board officials and those provided by community people with the exception of those provided by the attorney who filed the 1970 and 1987 desegregation lawsuits against the School Board (Allen). Even though he is a community person who sued the School Board of Broward County twice, his answers were more consistent with those given by School Board officials. In fact, he was critical of the community activists. In his affidavit and deposition, he was a staunch supporter of the School Board. It became difficult to separate him from School Board officials (Citizens Concerned About Our Children, 1995b; Washington, et al., vs. Broward County, 1994a).

The School System seemed to have created a culture of unanimity and sought retaliation against those who opposed the views and decisions of the hierarchy. Perhaps this can be explained by Galbraith's insightful statement when he said that organizations develop mechanisms to ensure the conditioning of its members, because nothing is more effective in threatening the external power of organizations than is the "undisciplined expression of dissenting views from within" (Galbraith, 1983, p. 60).

Community. Citizens Concerned About Our Children was relentless in attacking School Board officials and George Allen in the media. CCC members wrote newspaper articles, made appearances on radio and television programs and were constantly being 
interviewed and quoted by reporters from newspapers and magazines. They also held fora in the community to disseminate their point of view. The power techniques of CCC members were so successful, that they forced George Allen to resign or withdraw as the attorney for Rae Smith, the plaintiff responsible for the 1987 Consent Decree (Citizens Concerned About Our Children, 1995a, 1995b, 1996, 1999; Fresh eyes, 1995; Marks, 1995b, 1995c; Nevins, 1995; New era begins, 1995; Work, 1995).

A flyer distributed by CCC stated that the School Board's practice of starbursting only black children was "immoral, evil, disrespectful and [showed] a thorough disregard for the black community and the quality of life of black people." It also stated that the practice of "starbursting destroyed neighborhoods, disrupted families and created hardships for parents and children" (Citizens Concerned About Our Children, 1995b; personal communication, Citizens Concerned About Our Children).

CCC portrayed their struggle as poorer blacks having to fight middle-class blacks. They often alluded to middle-class blacks acting as obstructionists (Citizens Concerned About Our Children, 1995a, 1996, 2000a, 2000b; Price, 1995d). T'Shaka shed light on this type of situation when he spoke about the growing schism between poor blacks and middle-class blacks, saying middle-class blacks and traditional black institutions have deserted poor blacks (T'Shaka, 1990). He stated that the best way to get around the black establishment was to form grassroots activities, which is what CCC did. He also said there is a black establishment in every black community that consists of influential black and white people who control the black community. These people and their organizational affiliation need to be identified. CCC did identify, talk to and write about them. 


\section{Compensation}

Those who were instrumental in developing, enforcing and implementing desegregation policies and practices were compensated. (See Tables 13, 14 \& 15). Dandy was promoted to Deputy Superintendent, the second-in-command in Broward County schools. Marko was retained as attorney to the School Board for over 30 years. George Allen was paid $\$ 200$ an hour for being a consultant on desegregation issues; he betrayed the interests and trust of the black community, and gained access to School Board officials to lobby them on behalf of corporate clients. (See Appendix C and D). Coercive Force

School Board officials. These officials used coercive force against those who opposed the School System's desegregation plan. School Board employees and community persons became the targets of retribution by the School System. The Superintendent cancelled a contract with the black newspaper, The Broward Times, because of its stance on desegregation and its support for CCC. School Board Attorney Marko lodged a verbal attack against CCC member Ernestine Price. Several School Board personnel were harassed and retaliated against as a result of their support for CCC and their opposition to the School Board's desegregation policies and practices. (Citizens Concerned About Our Children, 2000a; "School District Chief Goes After," 1995).

Community. The community threatened the School Board with lawsuits. George Allen filed two lawsuits against the School Board to force it to desegregate the schools and to make them more equitable. Prior to CCC, the NAACP threatened to file a lawsuit against the School Board because of inequities and disparities. They didn't file a lawsuit, 
but did file a complaint with the Office of Civil Rights along with another community group (Marks, 1991a; Work, 1991b).

CCC threatened to defeat the penny sales tax and to boycott the schools if the School Board did not end the starbursting of their children and reduce the inequities that existed between black students and their schools and white students and their schools. They successfully defeated the penny sales tax by a very large margin and settled a lawsuit against the School Board for $\$ 485,000$, but did not boycott the schools (Arthur \& Marks, 1995a, 1995b; Clayborne, 1995b; Hirschman, 1995; Kiffin, 1995b; Marks, 1995d; "Tax Initiative Suffers," 1995).

\section{Recommendations for Further Research}

Based on the findings and conclusions of this study, the following recommendations are made:

1. School districts throughout the country should evaluate their desegregation policies and practices. The evaluation criteria should be whether their desegregation policies and practices are benefiting or harming: black children, black families and the black community? If their desegregation policies and practices are harmful they need to end or modify them immediately. If black children, families or communities are not benefiting from their desegregation policies and practices, they need to question why those policies and practices exist and what they should be doing differently? This evaluation should be based on empirical, qualitative and quantitative data.

2. As Faltz and Leake (1996) stated in their research, there are a lot of assumptions regarding desegregation. These assumptions have hindered and restricted needed dialogue on the pros and cons on the advantages and disadvantages of 
desegregation policies and practices. School systems, civil rights organizations and community activists must not be afraid to re-examine desegregation policies and practices in order to discern the relevancy and practicality of desegregation policies and practices at this time in American society. Modifying desegregation policies to make them more pertinent to the state of contemporary society is not an abandonment of the idea or goal of integration, but rather can provide a more effective means of implementing the law.

3. In order to advance the dialogue on desegregation research, a longitudinal study, needs to be conducted. Such a study should compare the achievement between black students attending predominately black schools and predominately white schools. Those students who are or were forcibly bused for purposes of desegregation should be identified separately from those who attend or attended those schools voluntarily.

4. Research also needs to be conducted on the long-range and residual impact and effect of desegregation policies and practices on individual children, families and the community.

5. The community seemed to resent the way in which the School System in Broward County responded to their concerns regarding desegregation issues. Much of the negativity in both action and attitude that surrounded desegregation in Broward County, perhaps, could have been avoided if the School System had used a different approach with the community. The School Board needs to examine how it interfaces with, involves, and responds to the community regarding controversial issues. It can then design and implement a process that will embrace and engage the community. 
6. The School System and the community should re-examine the power strategies and techniques they used in fighting against each other to determine how productive these power techniques were to the well-being and success of the overall community. A collaboration and mediation process should be created to resolve controversial issues, before they spiral out of control.

7. The black community needs to determine for itself whether it wants substantive leaders or symbolic leaders. "Substantive" means leaders who are competent, and effective in addressing issues and concerns of interest and importance to the black community. "Symbolic" means, leaders who just hold high-status positions and are not necessarily competent, and who are not responsive to the concerns and interests of the black community and, thus, are not effective in addressing such concerns. If the black community wants substantive leadership, then it needs to hold black leaders accountable for addressing issues that are of concern to them. The black community must not allow or accept bureaucracies or the power structure to appoint their spokespersons or leaders for them. Just because a person holds a high-profile, high-status job, does not make that person a leader or spokesperson for black people.

8. The School Board and large public bureaucracies like the School System should not assume that one or two people are the chief spokespersons for the entire community and therefore, base their decisions on the recommendations of those few persons. The contemporary black community is diverse. The decision-makers need to find a way to obtain the broadest possible community input into the decision-making process. 
9. At all times, the community must maintain its position of independent "watch dog" and monitor the School System. Even if there is a relationship of collaboration, there must always be independence and a demand for accountability.

10. The School Board, as a body, must maintain clear boundary lines between itself as a policy-making body and School Board staff as enforcers and implementers of policy. What seemed to occur in Broward County is that the lines became so blurred that even when School Board members were inclined to change desegregation policies and practices, they were directed and influenced by School Board staff not to do so.

11. Individuals change through systematic, deliberate and purposeful learning. Individuals can and do change institutions and communities. The Human Resource and Development Department has an important role to play in helping to change the cultural climate in the School System by assisting School Board officials in becoming more collaborative, inclusive and open and less combative with parents and community activists. The Human Resource and Development Department should also assist with the training of parents and the dissemination of information to parents and community activists regarding School Board procedures and practices.

12. Individuals conducting this kind of research should have prior knowledge of, and/or involvement with the issues being researched. Because of this researcher's familiarity with the issue of desegregation in Broward County, she was able to immediately discern inaccurate information provided by the participants interviewed. She was also able to identify other data sources that countered the misinformation, and which offered a more accurate accounting of the events. 


\section{REFERENCES}

Adair, H. (1986). Trends in school desegregation: An historical case study of desegregation in Dayton, Ohio; Denver, Colorado; Los Angeles, California; and Seattle, Washington 1954-1985. Doctoral dissertation, Brigham Young University.

Alexander, A. (1995, March 26). New crusaders show no regard for an old hero. The Miami Herald, p. 2BR.

Allen vs. Board of Public Instruction of Broward County, Fla. (1979, July 31). Findings of fact, conclusion of law and final judgment. U.S. District Court Southern District of Fla. No. 70-31-Civ-TC.

Allport, G. (1953). The nature of prejudice. Cambridge: Addison-Wesley.

Armor, D. (1995). Forced justice: School desegregation and the law. New York: Oxford University Press.

Arthur, L. \& Marks, M. (1995a, May 25). Blacks seethe as board ok's school zones. The Miami Herald, p. 1 A.

Arthur, L. \& M. Marilyn. (1995b, September 20). Not one red cent more. The Miami Herald, p. 1 A.

Banker, D. (1995a, June 7). Activists file new law suit. Sun-Sentinel, p. 1 B.

Banker, D. (1995b, April 27). Busing battle continues at school boundary hearing. SunSentinel, pp. 1B, $7 \mathrm{~B}$.

Banker, D. (1995c, May 25). Parents blast desegregation efforts. Sun-Sentinel, pp. 1B, $5 \mathrm{~B}$.

Banker, D. (1995d, February 28). Students bused to integrated schools. Sun-Sentinel, pp. 1A, $21 \mathrm{~A}$.

Banker, D. (1995e, May 14). Lawyers take up battle. Sun-Sentinel, pp. 1B, 7 B.

Banker, D. (1995f, May 10). Lawsuit authority passed on. Sun-Sentinel, pp. 1B, 4B.

Banker, D. \& Hirschman, B. (1995, February 18) Desegregation plan weakened. SunSentinel, p. $1 A$. 
Banker, D. \& Williams, M. (1995, May 5). New desegregation rules sought. SunSentinel, pp. 1A, 12A.

Bell, D. (1980). Brown and the interest-convergence dilemma. In Derrick Bell (Ed.), Shades of brown: New perspectives on school desegregation (pp. 91-106). New York: Teachers College, Columbia University.

Bell, D. (1989). And we are not saved: The elusive quest for racial justice. New York: Basic Books.

Berg, B. (1998). Qualitative research methods for the social sciences (3rd ed.). Boston, MA: Allyn and Bacon.

Black children are being used by the school board. (1995, March 24). The Broward Times, p. 1.

Black leaders wanted to join in fight for our children's education. (1998, May 28). Westside Gazette, p. 6A.

Black parents, end starbursting now. (1995, March 17). The Broward Times, pp. 1, 2.

Black parents enraged at magnet program quotas. (1986, April 26). Westside Gazette, Section B.

Blacks will mount anti-tax campaign against school district unless. (1995, March 3). The Broward Times, p. 1.

Boehlin, K. (1990, June 21). School board agrees to strategy to alleviate educational abuse of blacks. Westside Gazette, B section.

Boursiquot, J. (1994, May 13). Misinformation is bad for the community. The Broward Times, p. 7.

Broward County Public Schools. (1998-1999). Annual update to the three-year educational equity plan.

Broward County Public Schools. (1997, February). Position papers.

Broward County's resegregated school system needs attention. (1996, May 18). Gazette Newspapers, Section B.

Broward County School Board. (1995, January). Superintendent's Desegregation Task Force Report. 
Brown, E. (1995, March 10). Enough is enough: Stop the disparate busing of black children. The Broward Times, p. 8.

Brown, T. (1995). Black Lies, White Lies: The truth according to Tony Brown. New York: Wm. Morrow \& Co., Inc.

Burritt, C. (1999, September 12). Charlotte Faces New challenge as bus order lifted. The Atlanta Journal, pp. B5.

Busing and boundaries. (1991, November 14). The Miami Herald, pp. 26A.

Carter, R. (1980). A Reassessment of Brown vs. Board. In Derrick Bell (Ed.), Shades of Brown: New perspectives on school desegregation (pp. 20-28). New York: Teachers College, Columbia University.

Citizens Concerned About Our Children. (1995a, June 23). Acts of desperation by the Broward County School Board. The Broward Times, p. 8.

Citizens Concerned About Our Children. (1995b, February 10). Citizens Concerned About Our Children school desegregation - community strategy. The Broward Times, p. 7.

Citizens Concerned About Our Children. (1996, October 11). We shall not be moved. The Broward Times, p. 8.

Citizens Concerned About Our Children. (1999, March 5). School board reneges on equity plan, insults black community. The Broward Times, p. 8.

Citizens Concerned About Our Children . (2000a, August 18). Grassroots push for educational equity involved many The Broward Times, p. 9.

Citizens Concerned About Our Children. (2000b, August 11). CCC says thanks Broward Times. The Broward Times, p. 8.

Citizens Concerned About Our Children speak out - setting the record straight solutions to starburst. (1995, April 7). The Broward Times, p. 1.

Citizens Concerned About Our Children (CCC) et al., Plaintiffs, vs. School Board of Broward County, Florida and Frank Petruzielo, Superintendent of Broward County School Board, Defendants. (1995a, June 5). Complaint for Injunction and Declaratory Judgment School Desegregation. U.S. District Court, Southern District of Fla. Case No 95-6517-Civ-Ryskamp. 
Citizens Concerned About Our Children (CCC) et al., Plaintiffs, vs. The School Board of Broward County, Florida and Frank Petruzielo, Superintendent of Broward County School Board, Defendants. (1995b, November 9). Affidavit of W. George Allen. Case No. 95-6517-Civ-Ryskamp.

Citizens Concerned About Our Children (CCC) et al., Plaintiffs, vs. School Board of Broward County, Florida and Frank Petruzielo, Superintendent of Broward County School Board, Defendants. (1997a, May 13). Omnibus Order. U.S. District Court, Southern District of Fla. Case No. 95-6517-Civ-Ryskamp.

Citizens Concerned About Our Children (CCC) et al., Plaintiffs, vs. The School Board of Broward County, Florida and Frank Petruzielo, Superintendent of Broward County School Board, Defendants. (1997b, April 11). Deposition of Lee A. Stepanchek. Case No. 95-6517-Civ-Judge Ryskamp.

Citizens Concerned About Our Children (CCC) et al., Plaintiffs, vs. The School Board of Broward County, Florida and Frank Petruzielo, Superintendent of Broward County School Board, Defendants. (1997c, February 26). Deposition of Lee A. Stepanchek. Case No. 95-6517-Civ-Judge Ryskamp.

Citizens Concerned About Our Children (CCC) et al., Plaintiffs, vs. School Board of Broward County, Florida and Frank Petruzielo, Superintendent of Broward County School Board, Defendants. (1998a, January 13). Final Judgment. U.S. District Court, Southern District of Fla. Case No. 95-6517-Civ-Ryskamp.

Citizens Concerned About Our Children (CCC) et al., Plaintiffs, vs. School Board of Broward County, Florida and Frank Petruzielo, Superintendent of Broward County School Board, Defendants. (1998b, January 13). Omnibus Order. U.S. District Court, Southern District of Fla. Case No. 95-6517-Civ-Ryskamp.

Clark, K. \& M. (1939). The development of consciousness of self and the emergence of racial identity in Negro children. Journal of Social Psychology 10, 591-599.

Clayborne, K. (1991, August 30). NAACP pushed fight against school board over integration and equal treatment of blacks. The Broward Times, p. 1.

Clayborne, K. (1995a, May 5). Judge blasts Broward School Board. The Broward Times, p.1.

Clayborne, K. (1995b, September 22). Penny sales tax goes down. The Broward Times, p. 1 .

Clayborne, K. (1995c, April 28). Why we can't wait to end starburst. The Broward Times, p. 8. 
Clayborne, K. (1995d, March 5). Settle CCC suit now. The Broward Times, p. 1.

Clayborne, K. (1995e, March 31). There's no turning back - stop busing or else! The Broward Times, p. 1.

Cuddy, D. L. (1983). A proposal to achieve desegregation through free choice. American Education, 19 (4), 25-31.

Current Issues in Education, Part II. (1997, April). League of women voters of Seattle education fund.

Doe, J. \& Shaq, J., vs. School Board of Broward County. (1997, Sept. 5). Order on Standing. U.S. District Court, Southern District of Fla. Case No 95-6517-CivRyskamp.

Domhoff, G.W. (1983). Who rules America now? A view for the 1980s. New York: Simon \& Schuster, Inc.

Dowell vs. Oklahoma City Board of Education. (1991) 498 U.S. 237.

Dubois, W.E.B. (1935). Does the Negro need separate schools? Journal of Negro Education, 4, 328.

Dye, T. (1972). Who's running America. Englewood Cliff, N.J.: Prentice-Hall, Inc.

Easton, S. (1994). Forty years after Brown, cities and suburbs face a rising tide of racial isolation. The Harvard Education Letter, X(1).

Eddings, J. (1997, July 28). Second thoughts about integration. U.S. News. Retrieved July 28, 2000, from http://www.usnews.com/usnew/issue/970728/28naac.htm.

Education: Major proposals. (1998, April). Public Agenda. Retrieved July 28, 2000, from http: www.publicagenda.org.

Edwards, P. (1996). African American parents involvement in schools. In Mwalimu J. Shujaa (Ed.), Beyond Desegregation: The politics of quality in African American schooling (pp. 138-159). Thousand Oaks: Corwin Press, Inc.

Eyler, J., Cook, V. \& Ward, L. (1983). Resegregation: segregation within desegregated schools. In Christine H. Rossell \& Willis D. Hawley (Eds.), The consequences of school desegregation (pp. 126-162). Phila.: Temple University Press.

Faltz, C. \& Leake, D. (1996). The all-black school: Inherently unequal or a culturebased alternative? In Mwalimu J. Shujaa (Ed.), Beyond Desegregation: The politics of quality in African American schooling (pp. 227-251). Thousand Oaks: Corwin Press, Inc. 
Fernandez, M. (1992, March 4) Suit seeks change in assignment of middle school. The Miami Herald. Section BR.

Ferrechio, S. \& Arthur, L. (2000, August 2). Black students assured equal access. The Miami Herald, p.1A.

Freeman, D. (1980). School desegregation law: promise, contradicting rationalization. In Derrick Bell (Ed.), Shades of brown: New perspectives on school desegregation (pp. 70-89). New York: Teachers College, Columbia University.

Freeman vs. Pitts. (1992) 112S Ct. 1430.

Fresh eyes, but no old blame. (1995, May 6). The Miami Herald, p. 26A.

Galbraith, J. (1983). The Anatomy of power. Boston, MA: Houghton Mifflin Co.

Gay, L. R. (1996). Educational research: Competencies for analysis and application (5th ed.). Englewood Cliffs, N.J.: Prentice Hall.

Good teaching matters. (1998 Summer). Thinking K-16 3 (2). The Education Trust.

Hamel, J. \& Fortin, D. (1993). Case study method. Thousand Oaks, CA: Sage.

Hare, B. \& Levine, D. (1984, August). Toward effective desegregated schools. U.S. Department of Education, National Institute of Education.

Hawley, W. \& Rosenholtz, S. (1986). Achieving quality integrated education. National Education Association.

Hirschman, B. (1995, June 2). Schools get ultimatum on busing. Sun-Sentinel, pp. 1A, $21 \mathrm{~A}$.

Hirschman, B. (1999, June 25). School report card. Sun-Sentinel, pp. 20A.

Ishoy, R. (1995, March 26). Activist's son: forced busing is demeaning. The Miami Herald, p. BR1.

Johnson, J. (1986). The distribution of the ability to respond to the academic needs of African American children and youth among Broward County Elementary Schools. Ft. Lauderdale, Florida: Nova University, Department of Education.

Jones, Richard. (1998, July 29). Blacks say schools should focus on academics more than integration, Seattle Times. Retrieved July 28, 2000, from http://archives.seattletimes.nwsource.com/cgi-bin/texis.cgi/jones. 
Joondeph, Bradley W. (1998 Spring). Skepticism and school desegregation. (76 Wash. U.L.Q. 161, Vol. 76, No.1). Washington University Law Quarterly.

Kennedy, A. (1995, March 16). A personal view: Take tough stand against busing [Commentary]. Sun Sentinel.

Kersten, K. (1995 March). Good intentions are not enough. Center for the American Experiment.

Kiffin, M. (1995a, June 9). School board hit with another desegregation suit, The Broward Times, pp. 1, 10.

Kiffin, M. (1995b, May 26). Blacks plan massive campaign against school tax hike. The Broward Times, p. 1.

Kiffin, M. (1995c, March 10). New attendance zones do little to eliminate Starbursting. The Broward Times, p. 1.

Kiffin, M. (1995d, March 31). Jim Crow school board - Still racist, separate - Unequal. The Broward Times, p. 1.

Kiffin, M. (1995e, February 24). Superintendent's desegregation plan approved. Starbursting still bone of contention. The Broward Times, p. 1.

Kiffin, M. (1995f, February 3). Desegregation Task Force upset with school superintendent. The Broward Times, p. 1.

Kiffin, M. (1995g, April 28). School board: A waste of time! Members out of touch with voters. The Broward Times, p. 1.

Kunen, J. (1996, April 29). The end of integration. Time Magazine 147 (18).

Lawrence, C. (1980). One more river to cross - recognizing the real injury in brown: A prerequisite to shaping new remedies. In Derrick Bell (Ed.), Shades of Brown: New perspectives on school desegregation (pp. 48-69). New York: Teachers College, Columbia University.

Leedy, P. (1985). Practical research: Planning and design. New York: Macmillan Publishing Company.

Lightfoot, S. (1980). Families as Educators: The forgotten people of Brown. In Derrick Bell (Ed.), Shades of Brown: New perspectives on school desegregation (pp.319). New York: Teachers College, Columbia University. 
Loury, G. (1997, April 23). Integration has had it day. New York Times. Retrieved July 28, 2000, from http:query.nytimes.com/gst/abstract.htm.

Mahard, R. \& Crain, R. (1981). Minority achievement: Policy implications of research. In Willis Hawley (Ed.), Effective school desegregation: Equity, quality and feasibility (pp.55-84). Beverly Hills: Sage.

Mahard, R. \& Crain, R. (1983). Research on minority achievement in desegregated schools. In Christine H. Rossell \& Willis D. Hawley (Eds.), The consequences of school desegregation (pp. 103-125). Phila.: Temple University Press.

Marks, M. (1990, April 18). Parents threaten legal action to resolve magnet-school woes. The Miami Herald, pp. 2BR.

Marks, M. (1991a, August 29). NAACP residents challenge schools. The Miami Herald, p. BR1.

Marks, M. (1991b, October 29). Magnet schools is a sellout. The Miami Herald, p. BR1.

Marks, M. (1991c, May 24) NAACP lawyer to examine school's integration progress. The Miami Herald, pp. 1BR, 5BR.

Marks, M. (1991d, May 12). Families say busing brought end to real neighborhood. The Miami Herald, pp. 1BR, 6BR.

Marks, M. (1992, March 4). Parents sue schools over desegregation. The Miami Herald, p. 6BR.

Marks, M. (1993, March 30). Integration shuts out schools neighbors. The Miami Herald, pp. 5BR, 4BR.

Marks, M. (1994, May 15). Separate - Still unequal. The Miami Herald, p. 1 A.

Marks, M. (1995a, June 2). Bus blacks, whites equally or not at all Broward Board told. The Miami Herald, pp. 1A, 18A.

Marks, M. (1995b, May 10). Lawsuit authority passed on. The Miami Herald, pp. 1B, $4 \mathrm{~B}$.

Marks, M. (1995c, May 5). Lawyer wants out of busing battle. The Miami Herald, pp. 1BR, 7BR. 
Marks, M. (1995d, February 11). Group may try to stop vote on tax for schools. The Miami Herald, p. 4BR.

Marks, M. (1995e, March 26). Focus of frustration: starbursting. The Miami Herald, p. $1 \mathrm{BR}$.

Marshall, T. (2000, August 2). Broward school board to pay nearly $\$ 500,000$ to end busing lawsuit by black children. Sun-Sentinel, p. 1B.

Masem, P. W. (1986). Resegregation: A case study of an urban school district. Doctoral dissertation, George Peabody College for Teachers.

Merriam, S. B. (1988). The case study research in education. San Francisco: JosseyBass.

Miller, R. (1984). Analyzing Marx: Morality, power and history. Princeton, N.J.: Princeton University Press.

Milliken vs. Bradley. (1977). 433 U.S. 267.

Mills, C. W. (1956). The power elite. New York: Oxford University Press.

NAACP education activists: Blacks may benefit from separate and unequal education. (1990, August 31). The Broward Times, pp. 1, 2.

NAACP pushes fight against school board over integration and equal treatment of blacks. (1991, August 31). The Broward Times, pp. 1, 4.

NAACP suspends Atlanta unit: repudiates school agreement. (1973, May). The Crisis Magazine, pp. 168-169.

Nevins, B. (1995, September 20). No sale: Voters veto tax. Sun Sentinel, p. 1A.

New era begins in Broward desegregation case. (1995, May 12). The Broward Times, $\mathrm{p}$. $1 \mathrm{~A}$.

Nowell, P. (1999, September 9). Judge halts racial busing, in N.C. Associated Press. Retrieved August 7, 2000, from http://www.elibrary.com/getdoc.cgi.

Orfield, G. \& Yun, J. (1999) Resegregation in American schools. The Harvard Review. The Civil Rights Project, Harvard University.

Owens, K. (1990, April 7). It's time to focus on equal access to high quality education, not integration. Sun-Sentinel, p. 23A. 
Patterson, M. (1984). The influence of the NAACP on federal educational policy. Doctoral dissertation, Memphis State University.

Payne, W. (1991, June 27). The unfilled promise of voluntary desegregation. The Miami Herald, p 19A.

Payne, W. (1994, June 21). Broward's magnet schools symbolize racial injustice [Editorial board]. The Miami Herald.

Peterman, A. (1995, April 20). When does the school board show good faith. Westside Gazette, $\mathrm{p} 1$.

Pfeffer, J. (1992). Managing with power. Boston, MA: Harvard Business School Press.

Porter, J. \& Washington, R. (1979). Black identity and self-esteem. Annual Review of Sociology 5, 53-74.

Price, E. (1995a, April 28). [Letter to the editor]. The Broward Times, p. 8.

Price, E. (1995b, March 15). Desegregation: The community has spoken. The Broward Times, p. 8.

Price, E. (1995c, March 10). Enough is enough: Stop the disparate busing of black children now. The Broward Times, p. 8.

Price, E. (1995d, February 17). If the shoe fits, wear it. The Broward Times, p. 8 .

Pugh, T. (1992, January 19). Lawyer makes no apologies for settling desegregation Suit. The Miami Herald, pp. 12A.

Race relations: Major proposals (1999, July). Public Agenda. Retrieved August 7, 2000, from http: www.publicagenda.org.

Resegregation of Public Schools: The third generation. (1989). Regional Desegregation Assistance Centers.

Rist, R. (1978). The invisible children: School integration in American society. Cambridge: Harvard University Press.

Rose, A. (1956). The Negro in America. Boston: Beacon Press. (a condensed version of An American Dilemma). 
Rosenberg, M. \& Simmons, R. (1971). Black and white self-esteem: The urban school child. Washington, D.C.: American Sociological Association.

Rumer, P. (1981). Citizen advocacy groups - an intervention strategy: A case study of the community coalition for school integration in Portland, Oregon. Doctoral dissertation, Portland State University.

Russell, B. (1938). Power. New York: W. W. Norton \& Company.

St. John, N. (1975). School desegregation. New York: Wiley.

Schofield, J. (1991). School desegregation and intergroup relations: A review of the literature. In Gerald Grant (Ed.), Review of research in education 17, pp. 335412. Washington, D.C.: American Educational Research Associates.

Schofield, J. \& Sagar, H. (1983). Desegregation, school practices, and student race relations. In Christine H. Rossell \& Willis Hawley (Eds.), The consequences of school desegregation. (pp. 58-102). Philadelphia: Temple University Press.

School board hit with another desegregation suit. (1995, June 9). The Broward Times, p. 1.

School desegregation - the unfinished agenda. (1991, May). Daisy Bates Educational Summits. National Association of Colored People.

School district chief goes after black press. (1995, April 14). The Broward Times, p. 1.

School Board of Broward County, Florida (1995 January). Desegregation Task Force Report.

School busing issue creates furor in Deerfield Beach. (1991, March 15). The Broward Times, pp. 1, 4.

Schools and segregation. (1991, August 31). The Miami Herald.

Scott, H. (1983, October). Responses of black school superintendents to forty-eight statements pertinent to school desegregation. New York, N.Y: National conference on education issues, Social Science Division of the Rockefeller Foundation.

Searching for Equity. (1998, January 17). The Miami Herald, p. 22A.

Smith, Rae vs. McFatter, William (1983 Febuary). Complaint for Injunction. U.S. District Court Southern District of Fla. Civil Action No. 83-6086. 
Smith, Rae vs. McFatter, William (1987 April). Order. U.S. District Court, Southern District of Fla. Case No. 81-6200-Civ. Ryskamp.

Smith, Rae vs. McFatter, William (1995, February 23). Transcript of proceedings, George Allen \& Ed Marko. U.S. District Court, Southern District of Fla. Case No. 83-6086-Civ. Ryskamp.

Smith, Rae vs. McFatter, William (1996a, June 13). Order of dismissal and termination of jurisdiction. U.S. District Court, Southern District of Fla. Case No. 83-6086Civ. Ryskamp

Smith, Rae vs. McFatter, William. (1996b, May 30). Transcript of hearing before Judge Ryskamp. U.S. District Court, Southern District of Fla. Case No. 83-6086-Civ.

Stake, R. (1994). Case Studies. In N. K. Denzin \& Y. S. Lincoln (Eds.), Handbook of qualitative research (pp. 236-247). Thousand Oaks: Sage.

Stephan. W. (1986). The effects of school desegregation: An evaluation 30 years after Brown. In M. Saks and L. Saxe (Eds.), Advances in applied social psychology. Hillsdale, N.J.: Erlbaum.

Talalay, S. (1999, February 25). Three for the children. Sun Sentinel, Section E.

Tax initiative suffers crushing defeat. (1995, September 20). The Broward Times, p. 1.

The congressionally mandated study of educational growth and opportunity. (1993). Prospects. Abt Associates.

The spook who sat by the door. (1995, March 17). The Broward Times, p. 1.

T'Shaka, O. (1990). The Art of Leadership. Richmond, CA: Pan Afrikan Publications.

Turner, R. (1994 May). Round two in Topeka. Emerge 5 (8), 34-35.

U.S. Commission on Civil Rights. (1967). Racial isolation in the public schools. Washington, D.C.: U.S. Government Printing Office.

Wartenberg, T. (1990). The forms of power. Philadelphia, PA: Temple University Press.

Washington, C. \& Waldman, A. (1994, April 1). Mission for Broward: Seek true equality in schools. The Miami Herald.

Washington, J. (1983). School desegregation: A study of the decision-making process in the Trenton public schools 1955-79. Doctoral dissertation, Rutgers State University of New Jersey. 
Washington, et al., Plaintiffs, vs. School Board of Broward County and Virgil L. Morgan, Defendants. (1994a, October 27). Deposition of George Allen. U.S. District Court, Southern District of Fla. Case No. 92-6177-Civ-Ryskamp.

Washington, et al., Plaintiffs, vs. School Board of Broward County and Virgil L. Morgan, Defendants. (1994b, Novmber 11). Deposition of Edward J. Marko. U.S. District Court, Southern District of Fla. Case No. 92-6177-Civ-Ryskamp.

Washington, et al., Plaintiffs, vs. School Board of Broward County and Virgil L. Morgan, Defendants. (1994c, September 30 ). Deposition of William Dandy. U.S. District Court, Southern District of Fla. Case No. 92-6177-Civ-Ryskamp.

Washington, et al., Plaintiffs, vs. School Board of Broward County and Virgil L. Morgan, Defendants. (1994d, September 14). Deposition of Lee. A. Stepanchek. U.S. District Court, Southern District of Fla. Case No. 92-6177-Civ-Ryskamp.

Washington, et al., Plaintiffs, vs. School Board of Broward County and Virgil L. Morgan, Defendants. (1995a, August 16). Order Granting Partial Summary Judgment. U.S. District Court, Southern District of Fla. Case No. 92-6177-Civ-Ryskamp.

Washington, et al., Plaintiffs, vs. School Board of Broward County and Virgil L. Morgan, Defendant. (1995b, April 27). Transcript of Hearing. U.S. District Court, Southern District of Fla. Case No. 92-6177-Civ-Ryskamp.

Wells, A. \& Crain, R. (1994). Perpetuation theory and the long-term effects of school desegregation. Review of Educational Research, 64 (4). 531-555.

Why Coral Springs? (1988, August/September) Profit, 4 (4), p. 54.

Wiley, E. (1994, May). Black America's quest for education. Emerge 5 (8), 30-44.

Williams, M. (1993, February 28). Schools becoming more segregated. Sun-Sentinel, pp. 1B, 5B.

Woodall, B. (1989, January 2). Busing burden rides with blacks. The Sun Tattler, pp. $1 \mathrm{~A}, 3 \mathrm{~A}$.

Work, D. (1991a, April 13). Black students bused more. Sun-Sentinel, p. B1.

Work, D. (1991b, September 6). U.S. to check whether schools are segregated. SunSentinel, p. 1B, 4B.

Work, D. (1991c, August 29). Unequal education alleged. Sun-Sentinel, Section B. 
Work, D. (1992, March 25). School desegregation failing, report says. Sun-Sentinel, p. $1 B$.

Work, D. (1995, June 24). Crusader quit -- but didn't give up. Sun-Sentinel, p. $1 \mathrm{~A}$. 
APPENDIX A

List of Interview Questions 


\section{INTERVIEW OUESTIONS FOR PARTICIPANTS}

1. When did you first get involved in school desegregation in Broward County?

2. What role did you play in school desegregation in Broward County?

3. How do you feel about your involvement in school desegregation in Broward County?

4. Who were the key actors or players in school desegregation in Broward County?

5. What was their involvement?

6. What factors were responsible for the creation of the original 1970 desegregation Court Order? The 1987 Consent Decree? The 1998 ruling declaring the School System unitary?

7. What are the three most important events in school desegregation in Broward County?

8. Rate them from the most important to the least important.

9. What was the best thing to come out of school desegregation in Broward County? The worst?

10. What could have been done differently with school desegregation in Broward County?

11. What effects did the original 1970 desegregation Court Order have on the way the School System operated? The 1987 Consent Decree? The 1998 ruling declaring the School System unitary?

12. What was good and what was bad about the original desegregation Court Order? The 1987 Consent Decree? The 1998 ruling declaring the School System unitary?

13. There are many stories of unintended consequences due to school desegregation in Broward County, do you know anything about these and can you think of others?

- starbursting

- black administrators and teachers being displaced and laid off.

- substandard facilities in predominately black schools.

- incompetent staff in predominately black schools.

- quota on hiring of black teachers in predominately black schools.

14. Who were the beneficiaries of school desegregation in Broward County?

15. From your perspective what was the response from the black and white communities to the School Board's desegregation plans? 


\section{APPENDIX B}

Responses from Interview and Archival Data Sources to Research Question \#1 
Question \#1: What are the factors that made school desegregation an important power issue in Broward County?

\begin{tabular}{|c|c|}
\hline INTERVIEW DATA & ARCHIVAL DATA \\
\hline Segregation and resegregation of schools & Segregation and resegregation of schools \\
\hline $\begin{array}{l}\text { Issues of equity in facilities, courses, resources and } \\
\text { education }\end{array}$ & $\begin{array}{c}\text { Issues of equity in facilities, courses, resources and } \\
\text { education }\end{array}$ \\
\hline & Depositions \\
\hline $\begin{array}{l}\text { 1. Black children denied extracurricular activities } \\
\text { and academic clubs. }\end{array}$ & $\begin{array}{l}\text { 1. School board spent less on black schools than on } \\
\text { white schools. }\end{array}$ \\
\hline 2. Unequal conditions in black and white schools. & 2. Unequal facilities in black schools. \\
\hline 3. Unequal allocation of resources and money. & Herald \\
\hline 4. Under-education of black children. & 3. Building of white schools out west. \\
\hline 5. System denied children an equal education. & Broward Times and Sentinel \\
\hline 6. Black children prohibited from attending magnet & 4. Black students excluded from magnet programs. \\
\hline programs. & 5. Unequal education of black students. \\
\hline $\begin{array}{l}\text { 7. Black children had no or few current textbooks } \\
\text { and couldn't check out library books. }\end{array}$ & \\
\hline 8. Black children were tracked/grouped. & \\
\hline 9. Buillding white schools out west. & \\
\hline $\begin{array}{l}\text { 10. School desegregation policies and practices unfair } \\
\text { to eastern communities and black people. }\end{array}$ & \\
\hline $\begin{array}{l}\text { 11. Black children were excluded from magnet } \\
\text { programs. }\end{array}$ & \\
\hline $\begin{array}{l}\text { 12. People placed in jobs because of race rather than } \\
\text { qualifications. }\end{array}$ & \\
\hline 13. Incompetent staff in black schools. & \\
\hline Issues related to the busing of students & Issues related to the busing of students \\
\hline 1. Black parents feeling intimidated because of low & $\begin{array}{l}\text { Depositions } \\
1 . \text { Black children disproportionately bused. }\end{array}$ \\
\hline & 2. "One Child or Adverse Impact Rule." \\
\hline 2. The mismatch of socioeconomic groups. & Transcripts \\
\hline 3. Distant busing. Inconvenience of busing for & 3. Starbursting \\
\hline stuc & Broward Times and Herald \\
\hline 4. Black parents and students could not attend events & 4. Black students bused to all black schools. \\
\hline $\begin{array}{l}\text { and participate because of transportation. } \\
5 \text { White flight }\end{array}$ & $\begin{array}{l}\text { 5. Students from white western communities were not } \\
\text { bused. }\end{array}$ \\
\hline 6. Busing caused division between the races. & \\
\hline 7. Starbursting; unequal busing of black kids. & \\
\hline 8. Busing black children to black schools. & \\
\hline 9. White schools were hostile to black children. & \\
\hline $\begin{array}{l}\text { 10. Children did not have after-school care or friends } \\
\text { in the community. }\end{array}$ & \\
\hline
\end{tabular}

Information contained in Appendix B is based on the following references:

("Busing and Boundaries," 1991; Citizens Concerned About Our Children, 1999; Citizens Concerned About

Our Children vs. Broward County ,1995b, 1997b,1997c; Clayborne, 1991,1995a,1995e; Kiffin 1995e, 1995g; Marks,

199lc, 1995a, 1995c; Price 1995a; Pugh, 1992; "Schools and Segregation," 1991; Smith vs. McFatter, 1995;

"The Spook Who Sat."1995; Washington vs. Broward County . 1994a, 1994b, 1994c, 1994d, 1995b; Work, 1991c).

The information above represents the responses to the interview questions by individuals interviewed (school board officials and community activists) and from the archival data sources. 


\section{APPENDIX C}

Responses from Interview and Archival Data Sources to Research Question \#3 


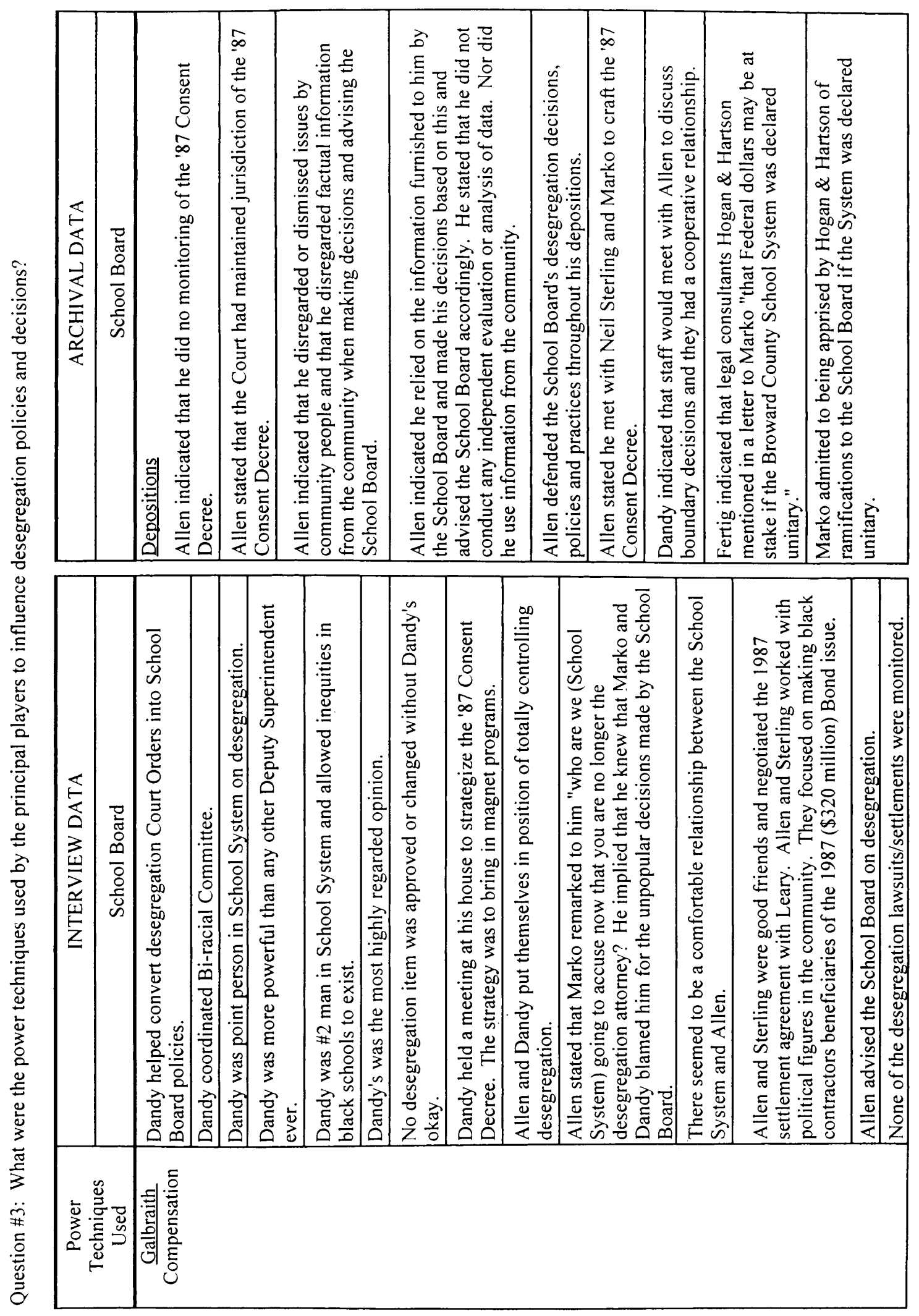




\begin{tabular}{|c|c|c|c|c|c|c|c|c|}
\hline$\approx$ & 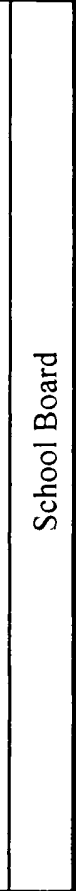 & 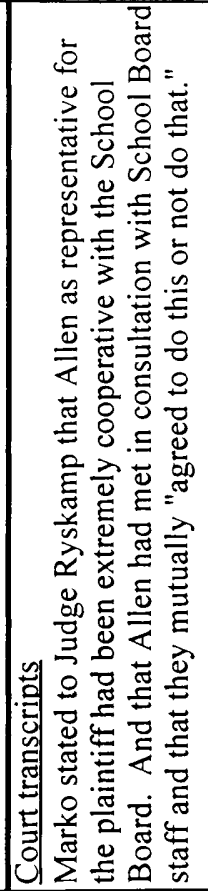 & 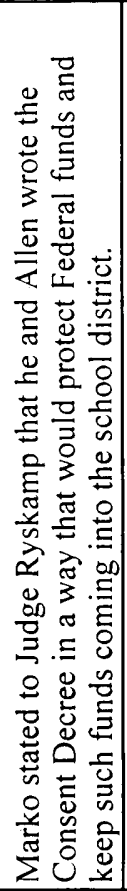 & 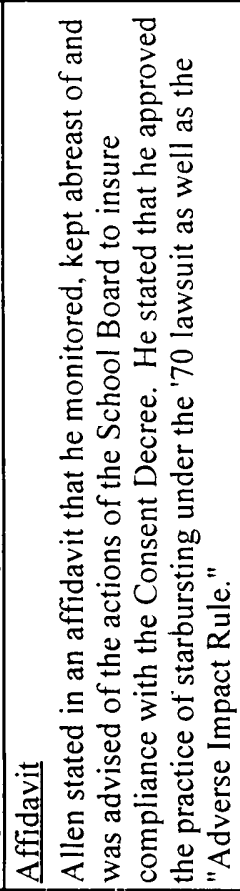 & 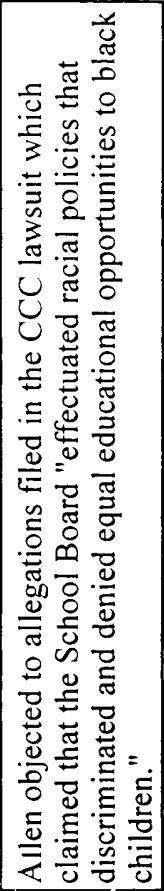 & 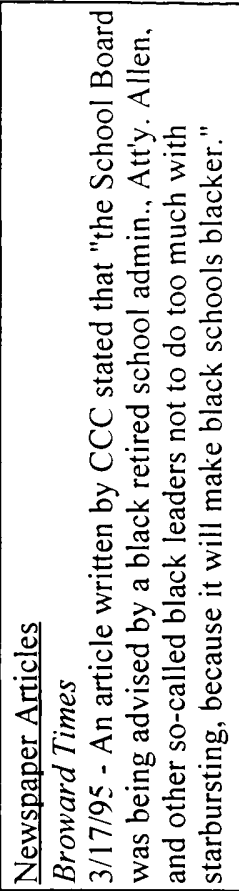 & 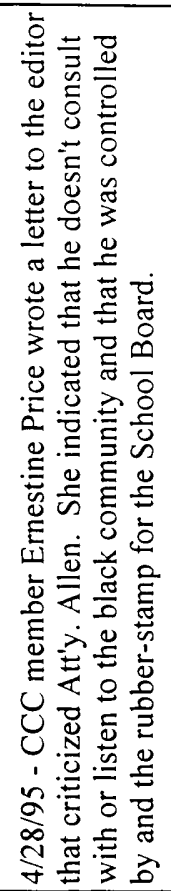 & 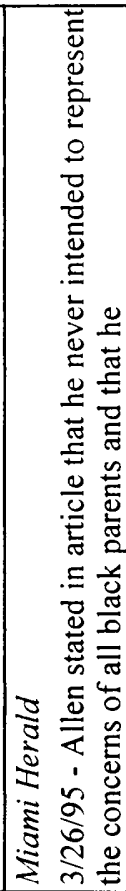 \\
\hline
\end{tabular}

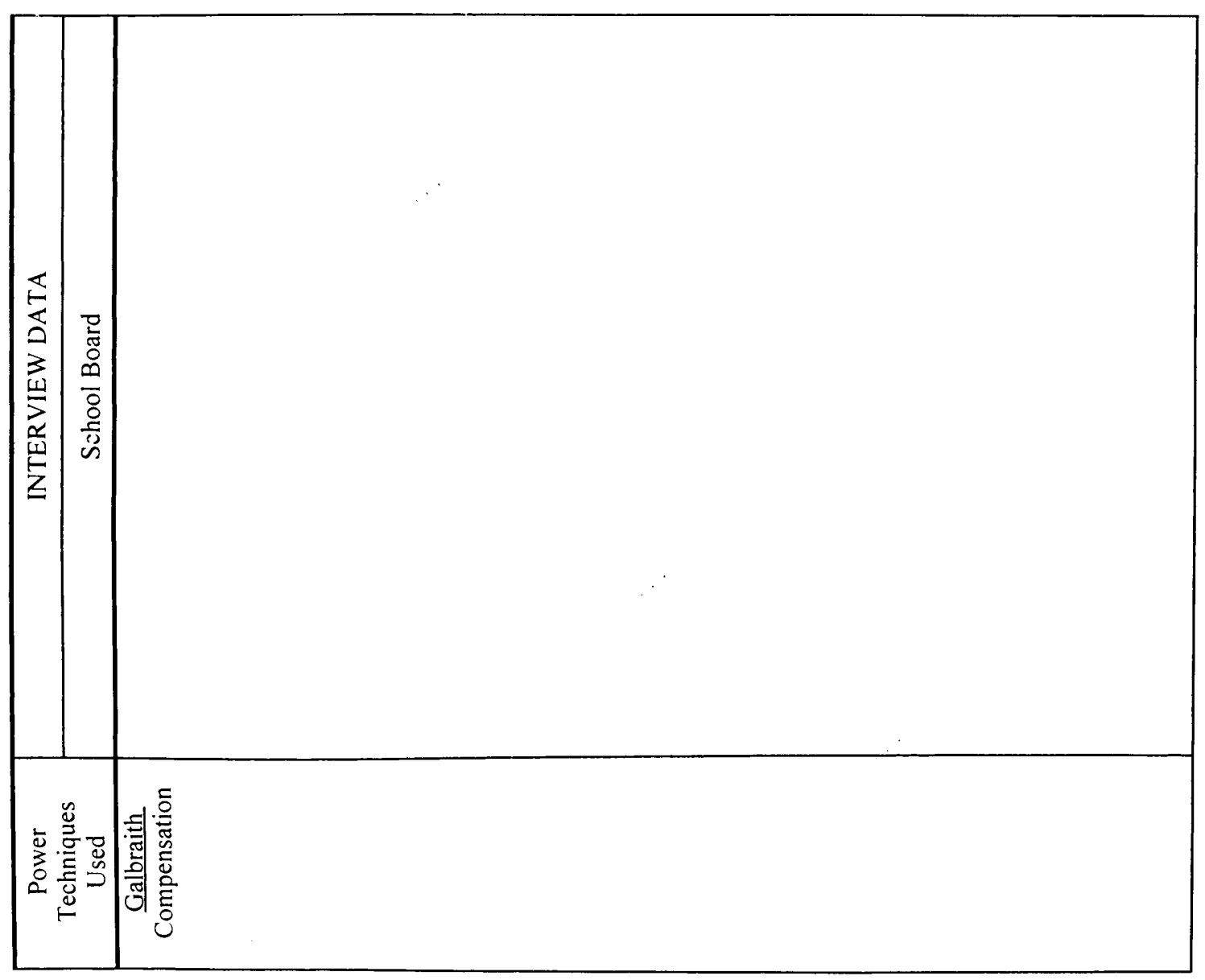




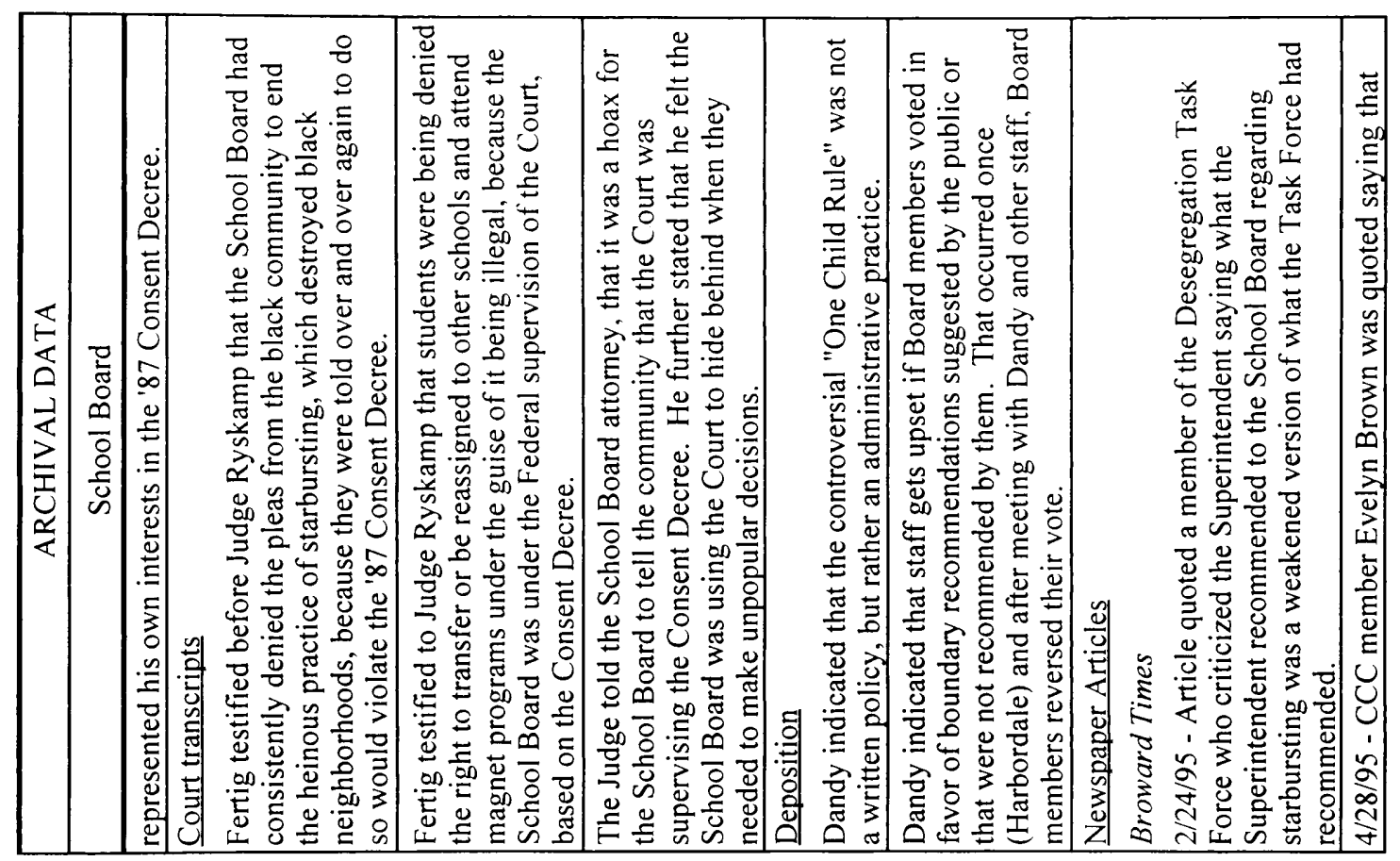

\begin{tabular}{|c|c|c|c|c|c|c|c|c|c|c|c|c|c|c|c|c|c|c|c|}
\hline 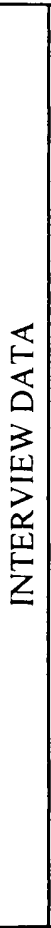 & 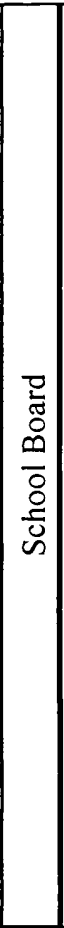 & 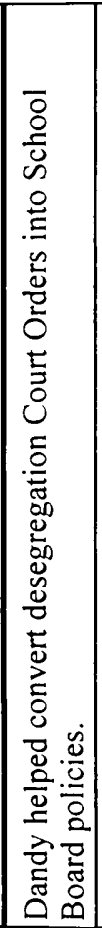 & 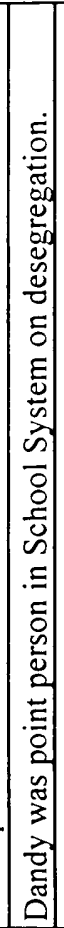 & 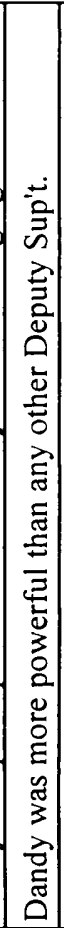 & 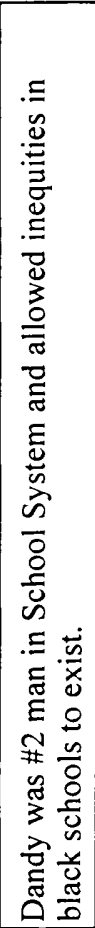 & 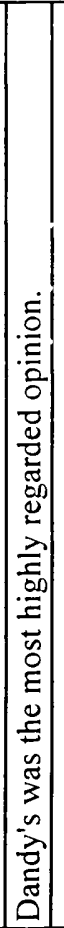 & 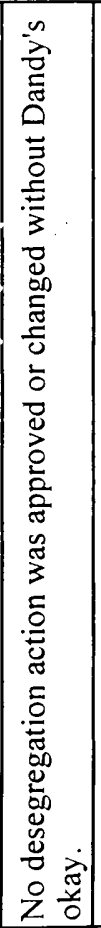 & 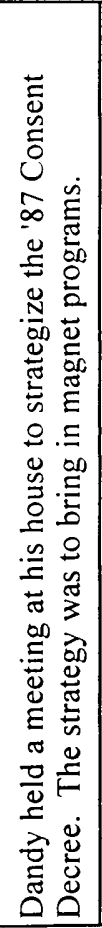 & 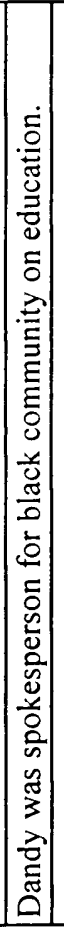 & 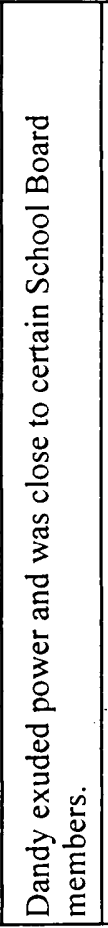 & 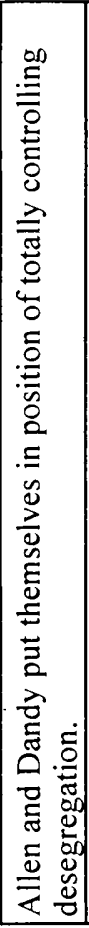 & 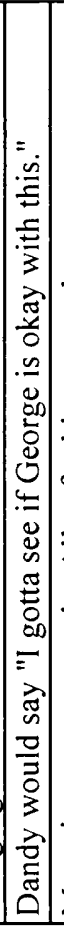 & 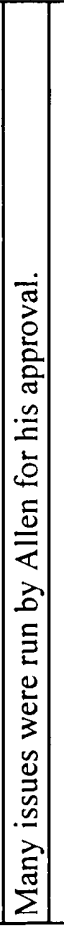 & 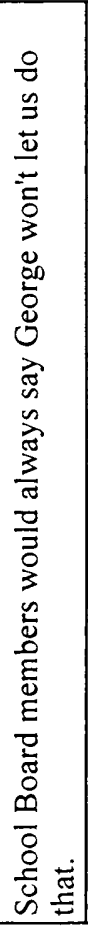 & 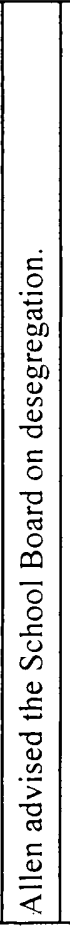 & 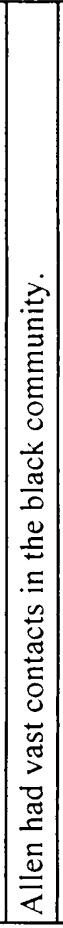 & 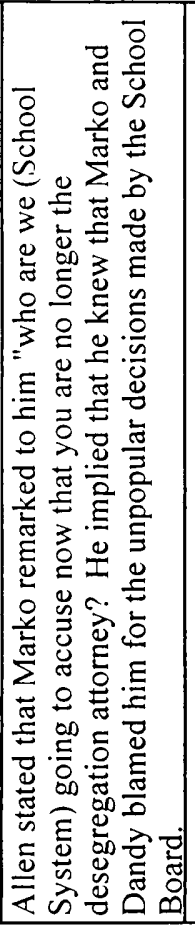 & 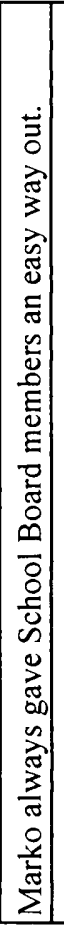 & 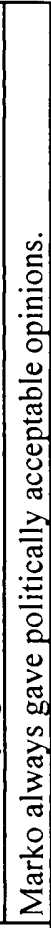 \\
\hline & & 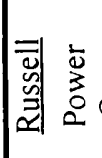 & 8 & & & & & & & & & & & & & & & & \\
\hline
\end{tabular}



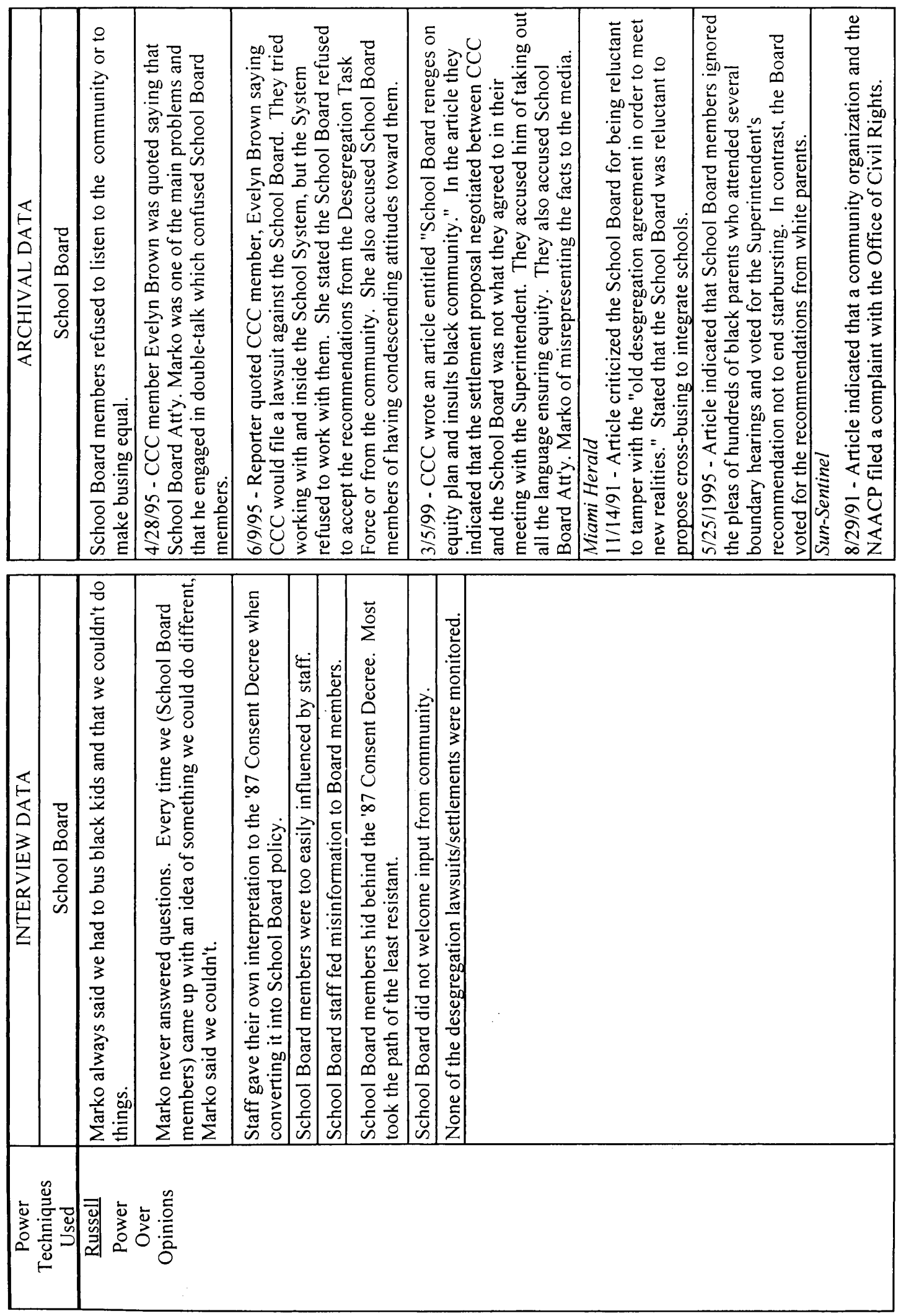


\begin{tabular}{|c|c|c|c|c|c|c|c|c|c|c|c|}
\hline 0 & 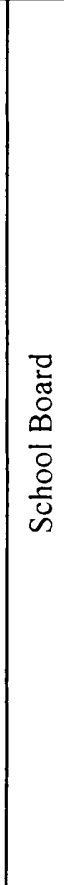 & 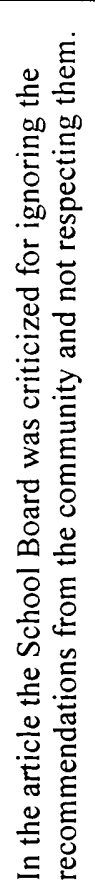 & & 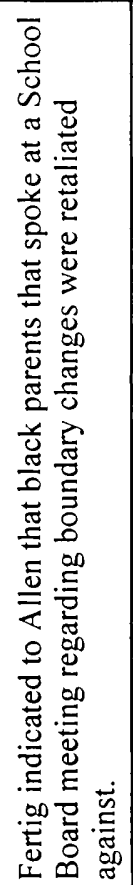 & 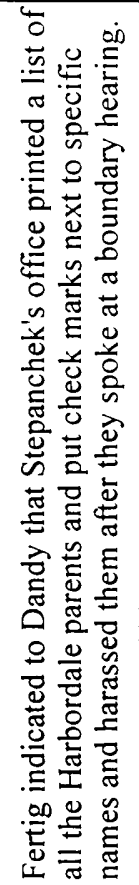 & 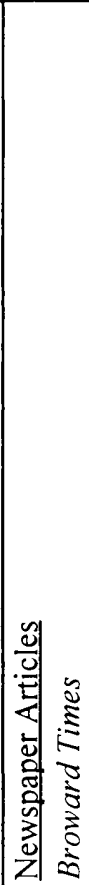 & 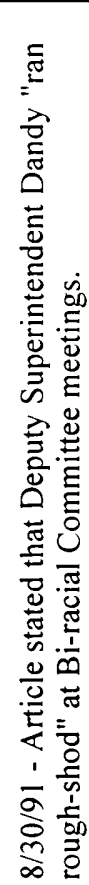 & 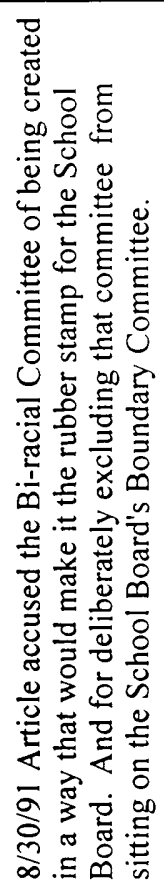 & 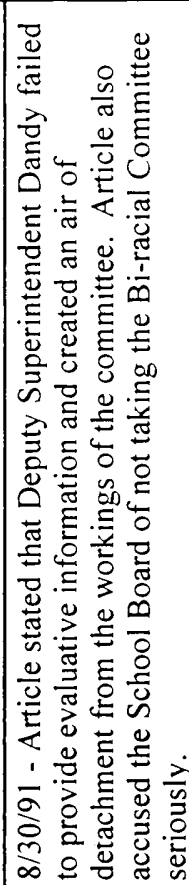 & 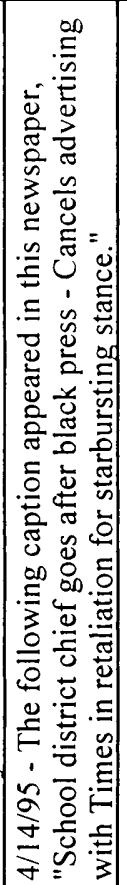 & 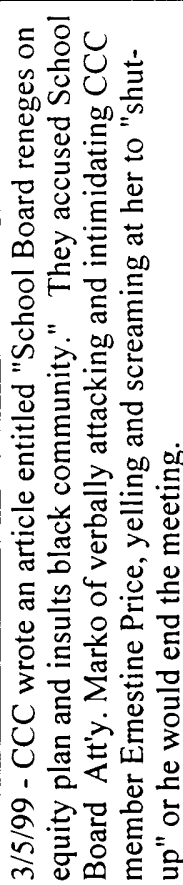 \\
\hline
\end{tabular}

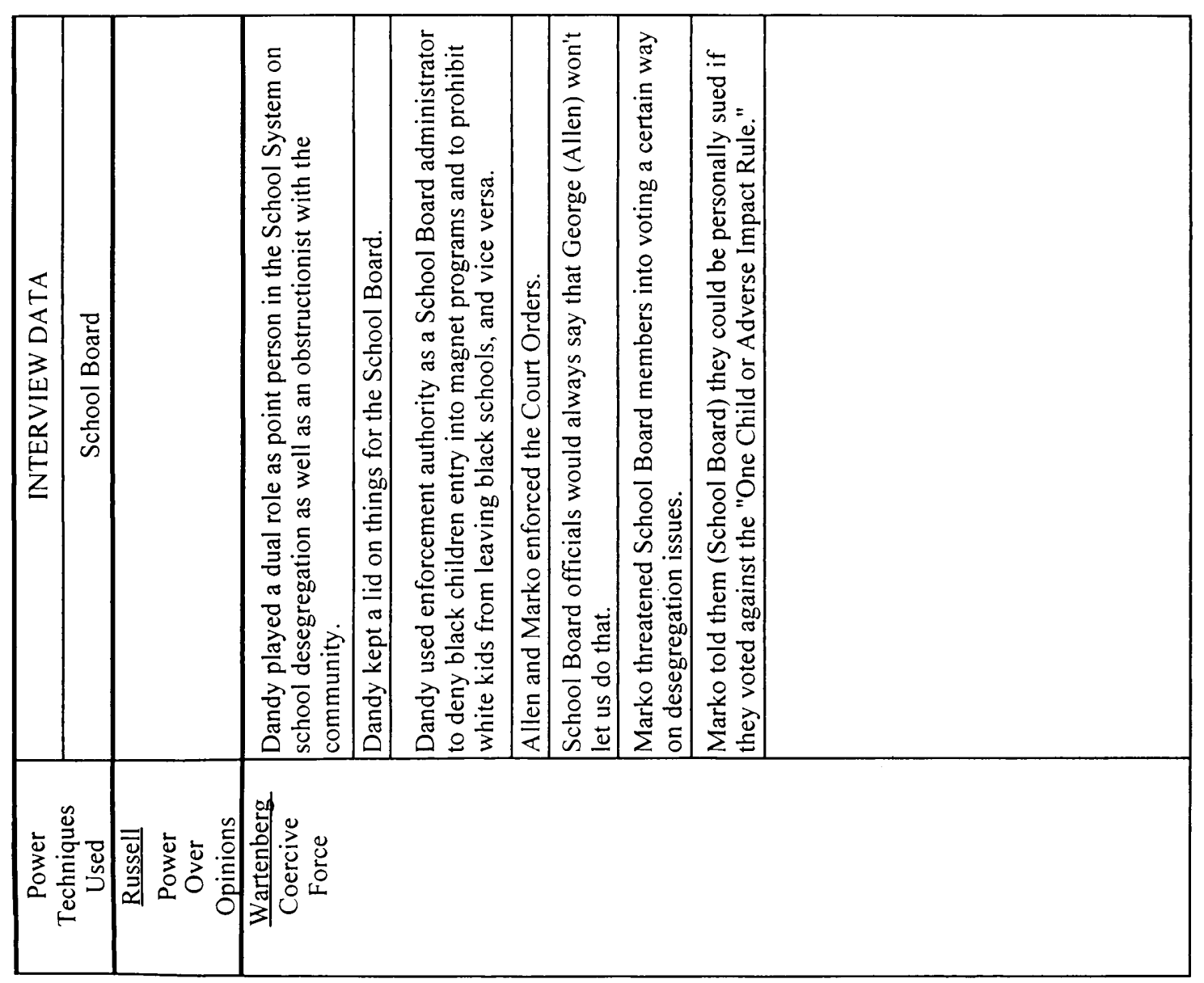



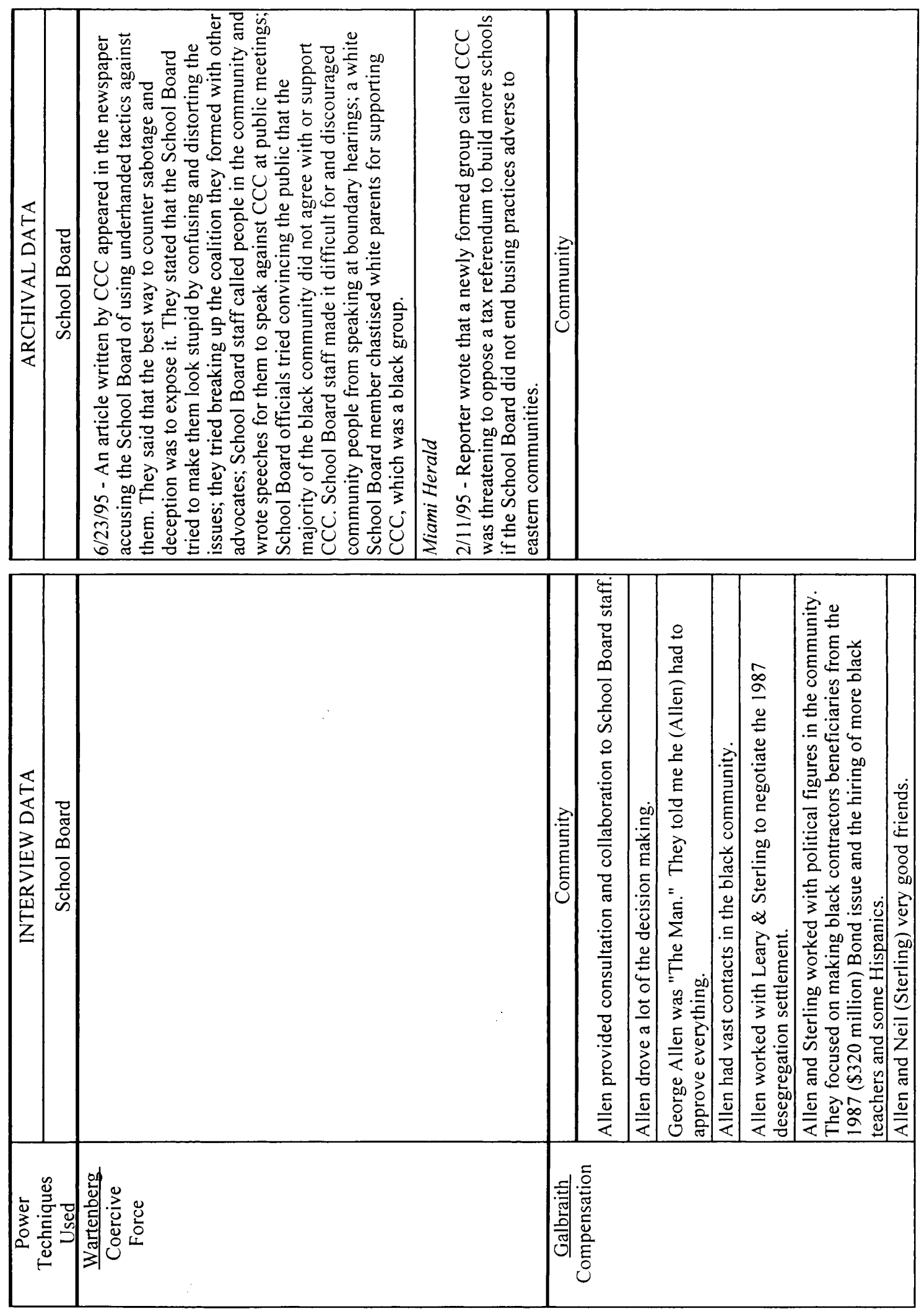


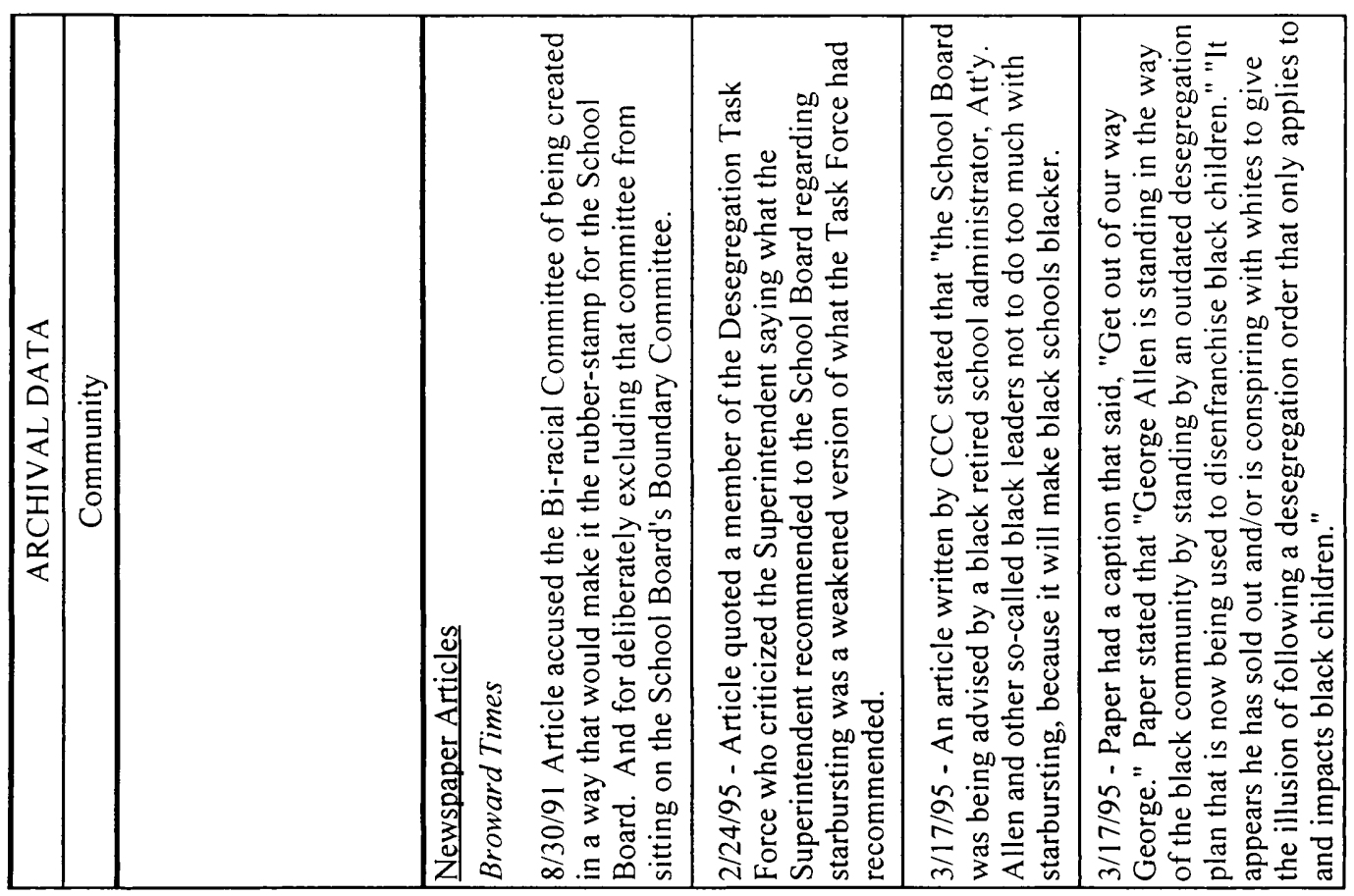

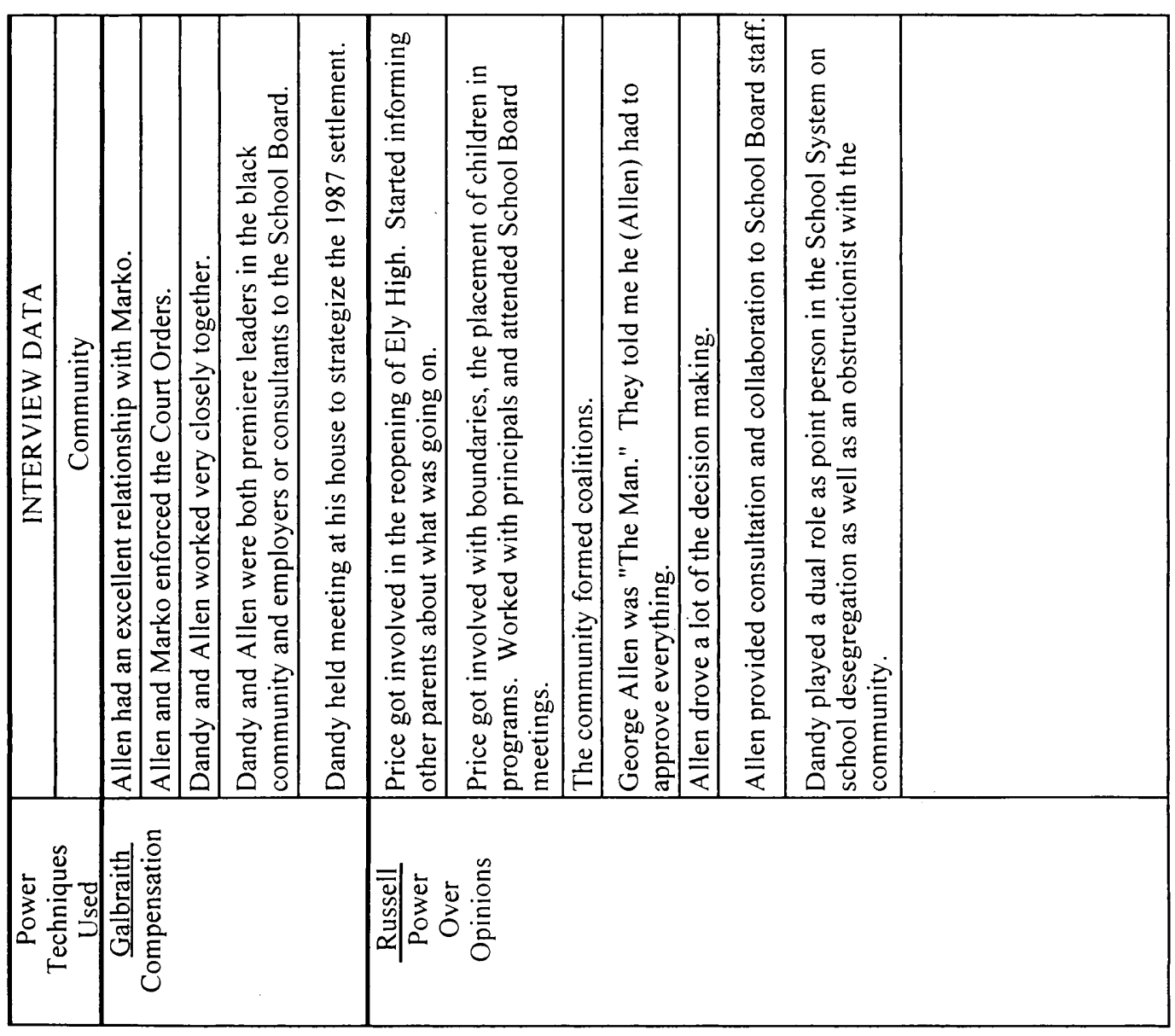




\begin{tabular}{|c|c|c|c|c|c|c|}
\hline 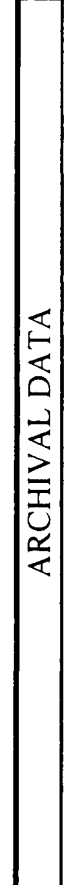 & 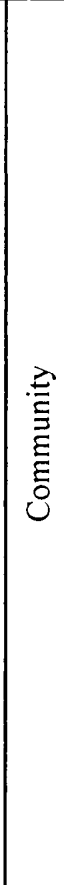 & 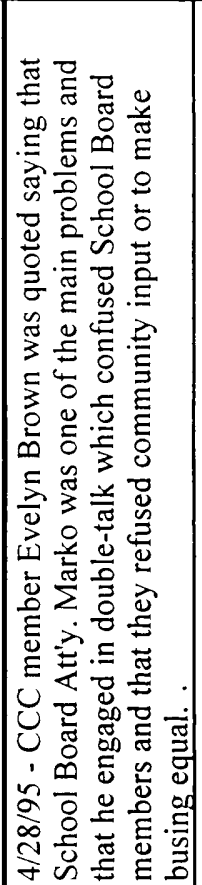 & 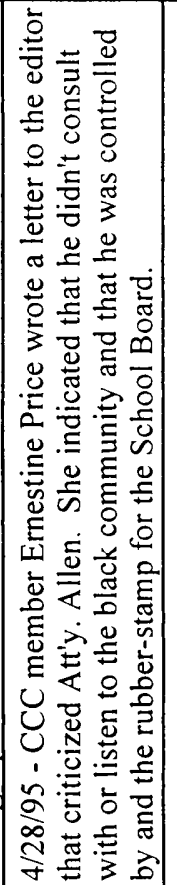 & 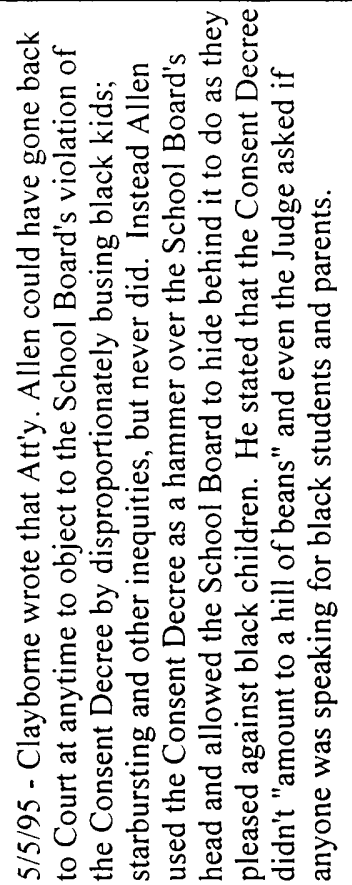 & 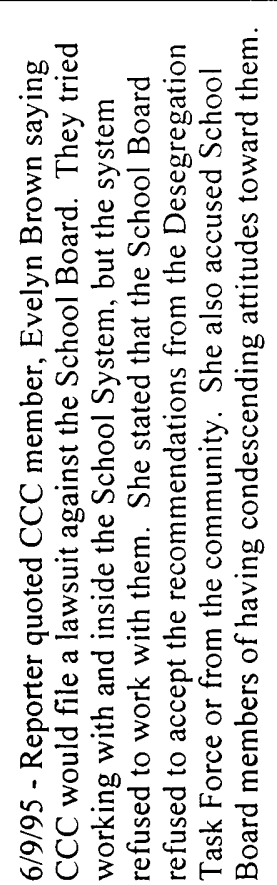 & 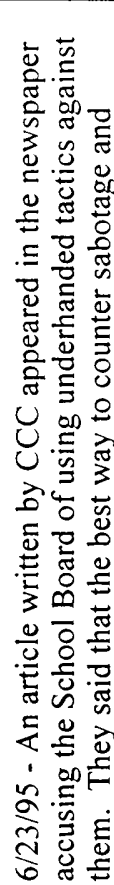 \\
\hline
\end{tabular}

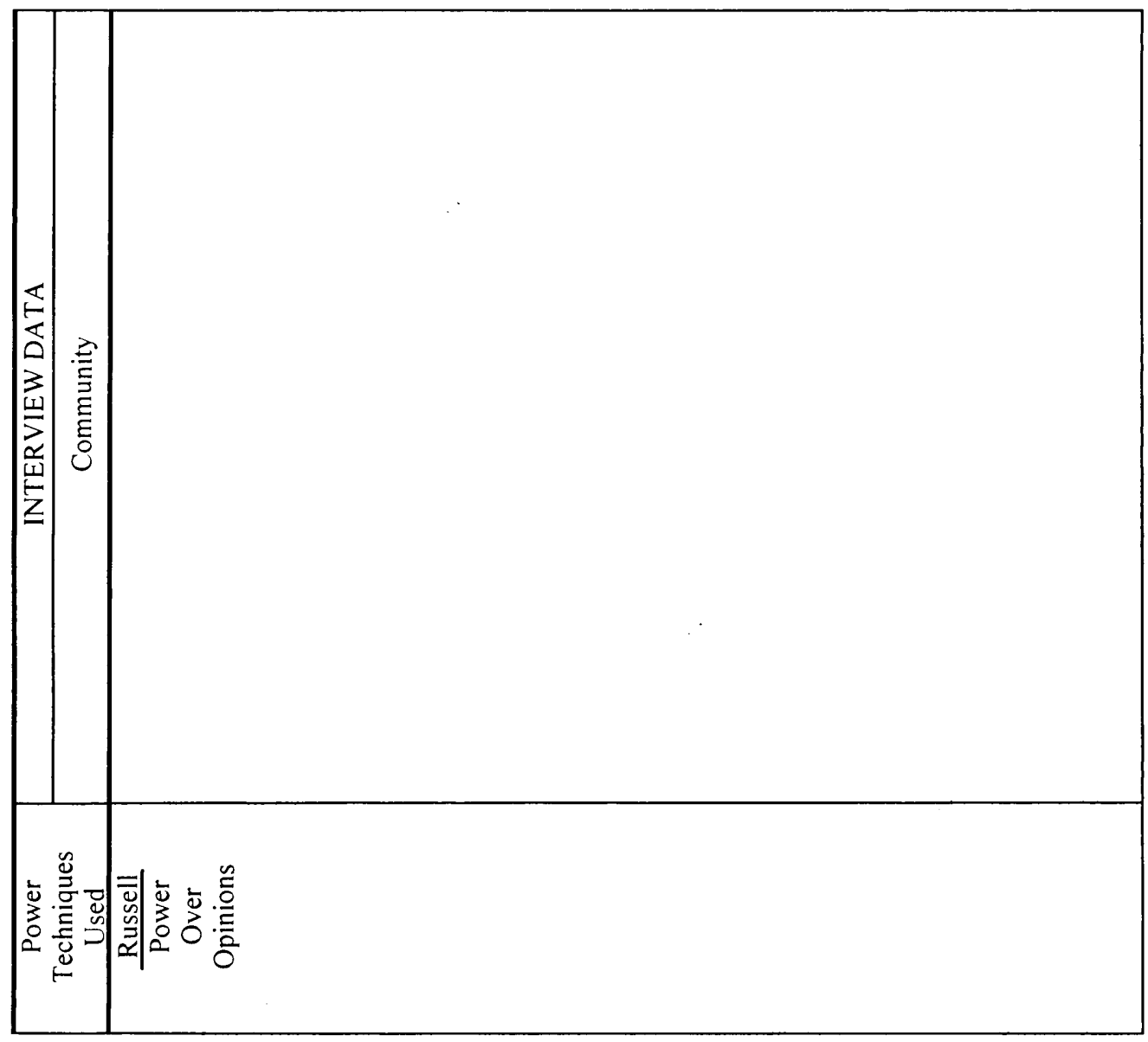




\begin{tabular}{|c|c|c|c|c|c|c|c|c|}
\hline 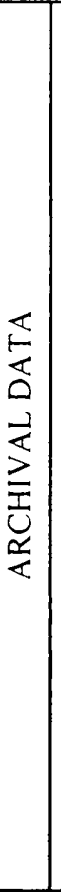 & 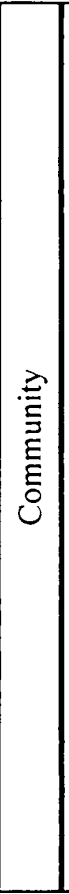 & 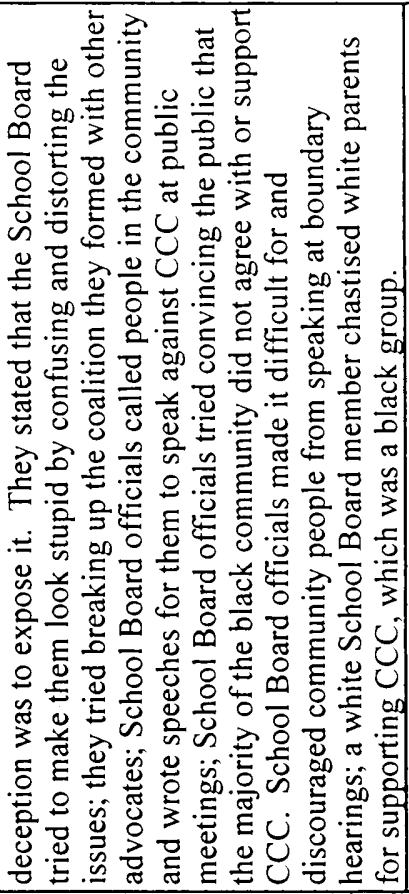 & 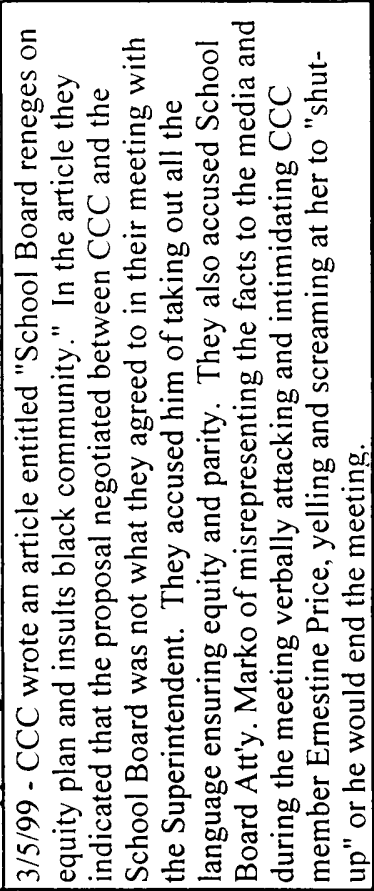 & \multicolumn{2}{|c|}{ 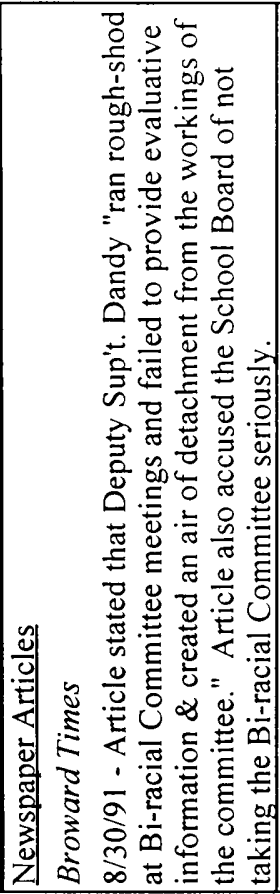 } & \multicolumn{2}{|c|}{ 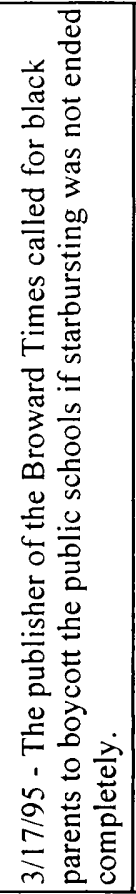 } & 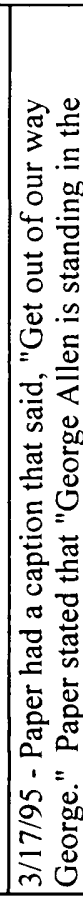 \\
\hline 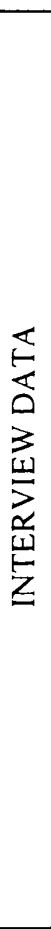 & 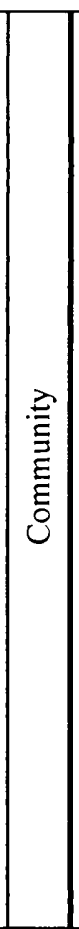 & & & 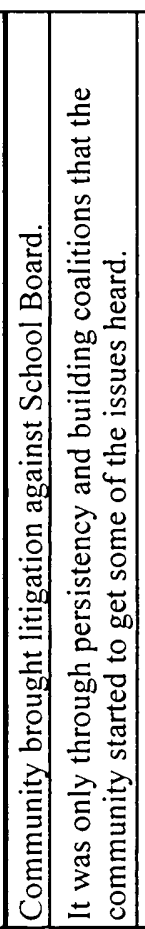 & 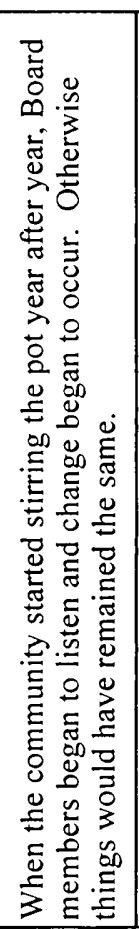 & 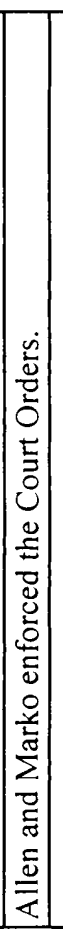 & 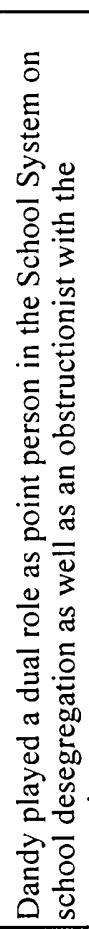 & 离 \\
\hline & 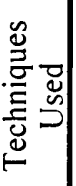 & 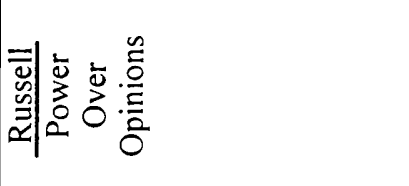 & & 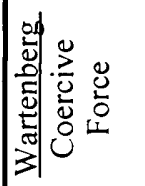 & & & & \\
\hline
\end{tabular}




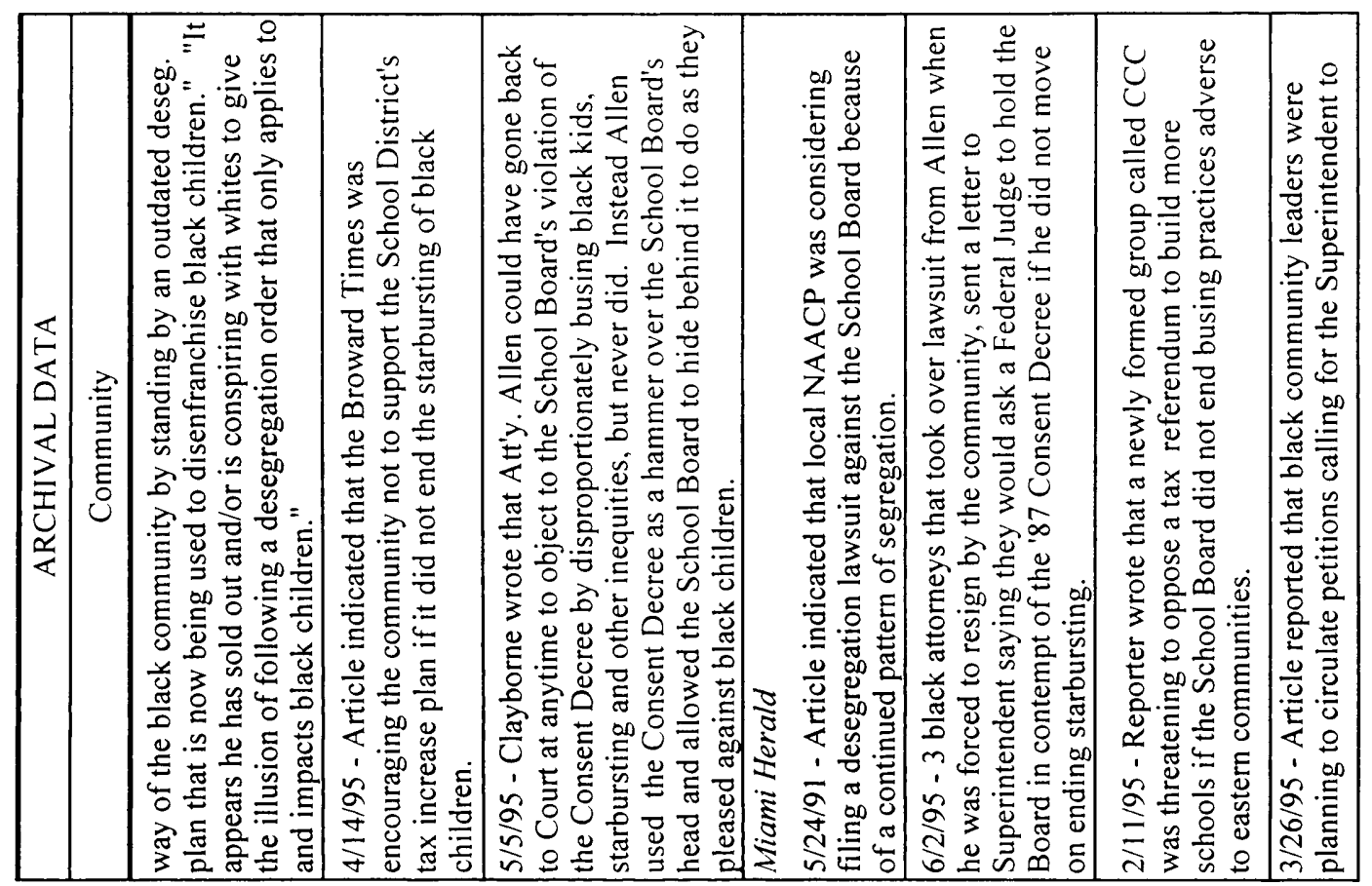

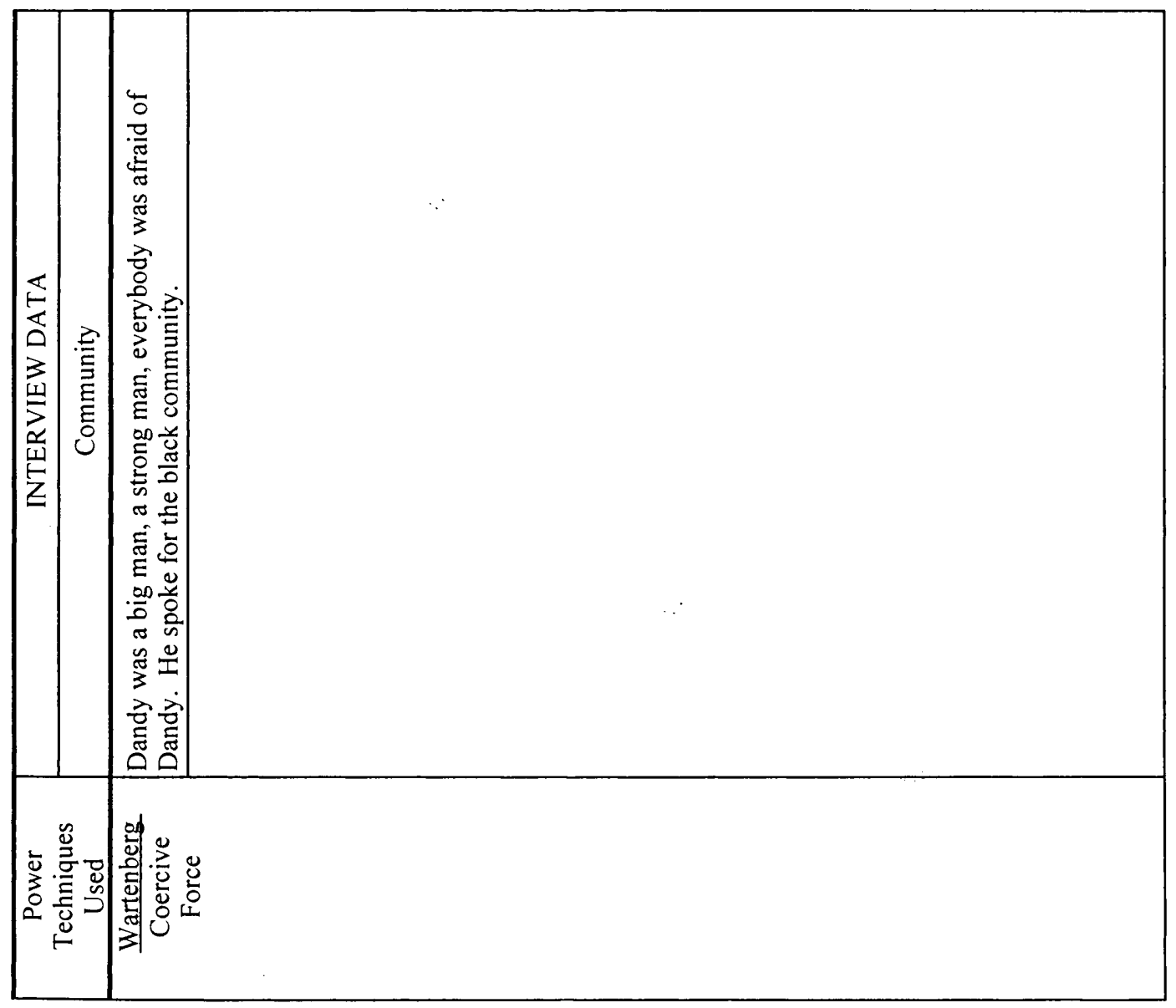




\begin{tabular}{|c|c|c|c|c|c|c|}
\hline $\begin{array}{l}2 \\
2 \\
2\end{array}$ & 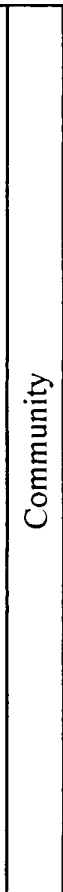 & 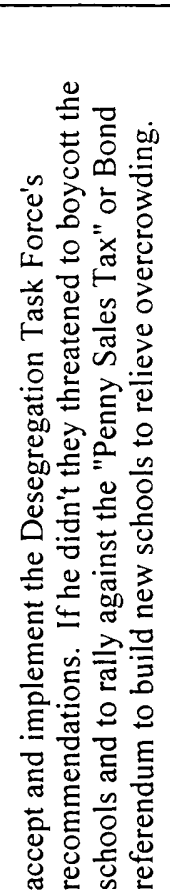 & 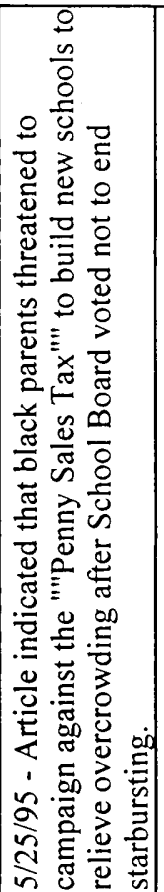 & 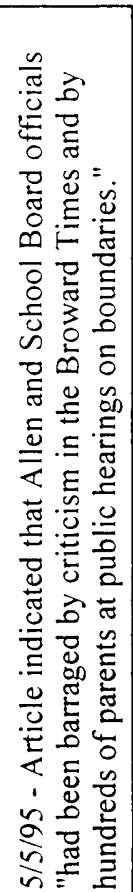 & 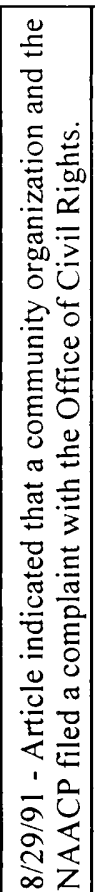 & 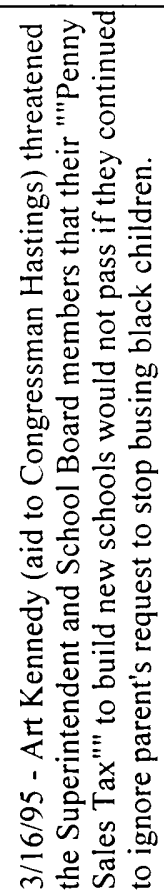 \\
\hline
\end{tabular}

कं

㐫苟

일

密

文 응

过 क

ลㄹ

๙ั๊

응 듕

बूे

एड

造定

产弯

iे

施

$\frac{a}{0} \ddot{2} \dot{0}$

응 흥

iी.

.

$\ddot{8}$ 응

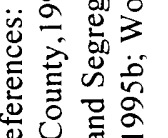

on 면 뜽 或

产造造

vi

Е

ธิ

वूँ

वृ

$\approx 0 \stackrel{2}{2}$

$\times$ ㄴ..

产号

$\frac{2}{2}=$

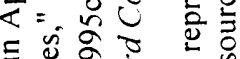

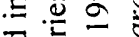

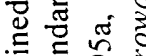

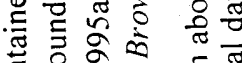

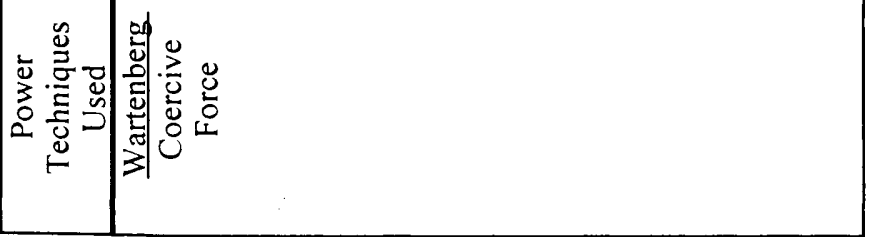

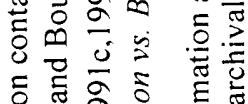

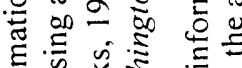

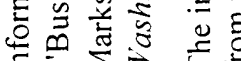

